\title{
CLONAGEM E MAPEAMENTO MOLECULAR DO GENE DE RESISTÊNCIA AO METOLACHLOR EM Saccharomyces cerevisiae
}

\author{
NIRLEI APARECIDA SILVA \\ Bióloga
}

Orientador: Prof. Dr. FLAVIO CESAR ALMEIDA TAVARES

Dissertação apresentada à Escola Superior de Agricultura "Luiz de Queiroz", da Universidade de São Paulo, para obtenção do título de Mestre em Agronomia, Área de Concentração: Genética Melhoramento de Plantas.

P I R A C I C A B A

Estado de São Paulo - Brasil

Março - 1995 
Dados internacionais de Catalogação na Publicação (CIP)

Divisão de Biblioteca e Documentação - CAMPUS "LUIZ DE QUEIROZ"/USP

Silva, Nirlei Aparecida

Clonagem e mapeamento molecular do gene de resistência ao metolachlor

en Saccharomyces cerevisiae. Piracicaba, 1995.

94p. ilus.

Diss. (Mestre) - ESALQ

Bibl iografia.

1. Clonagem 2. Gene - Mapeamento genético 3. Levedura - Genética molecú lar 4. Levedura - Resistência ao herbicida I. Escola Superior de Agricult tu ra Luiz de Queiroz, Piracicaba

CDD $\quad 589.23$ 


\section{CLONAGEM E MAPEAMENTO MOLECULAR DO GENE DE RESISTÊNCIA AO METOLACHLOR EM Saccharomyces cerevisiae}

NIRLEI APARECIDA SILVA

Aprovada em: 11/04/1995

Comissão julgadora:

Prof. Dr. Flavio Cesar Almeida Tavarez

ESALQ/USP

Profa. Dra. Aline Aparecida Pizzirani-Kleiner

ESALQ/USP

Profa. Dra. Marisa Vieira de Queiroz

ESALQ/USP

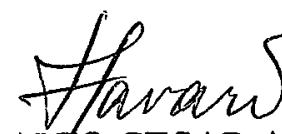

Prof. Dr. FLAVIO CESAR ALMETDA TAVARES

Orientador 
Aos meus pais Lazaro e Antonia;

Aos meus irmãos, Lúcia, Roberto, Wisler e Silvia,

pelo apoio, compreensão e carinho sempre constantes;

Aos meus sobrinhos, Thiago, Giovana, Mayara e Carolinie, por proporcionarem-me tanta paz, alegria e esperança.

DEDICO

À minha querida amiga Lianna (in memorian) pelo exemplo de força, determinação e bondade; com saudades.

OFEREÇO 


\section{AGRADECIMENTOS}

- À DEUS, pelo dom da vida, por cada dia e pela luz no horizonte;

- Ao Prof. Dr. Flavio Cesar Almeida Tavares, pela preciosa orientação desde minha iniciação científica até a elaboração deste trabalho; pela compreensão, respaldo, confiança e atenção. A este ser humano ímpar, com respeito e admiração, minha eterna gratidão;

- À Prof. Dr ${ }^{a}$. Aline A. Pizzirani-Kleiner, pela amizade, apoio, valiosas contribuições e concessão de um espaço no Laboratório de Genética de Fungos Filamentosos da ESALQ/USP, onde foi possível a realização de parte deste trabalho. Com carinho, obrigado;

- Às minhas amigas Vânia, Adriana, Vilma, Renata, Flor e Cleide, pelo carinho e apoio recebido em diferentes situações;

- Ao João Teixeira Junior, Aline Saraiva Teixeira e familia pela preciosa amizade, pelo carinho, apoio, ternura e a satisfação de ter mais uma família;

- Ao Bacharel em Ciências Jurídicas Adson Vasconcellos de Oliveira, por incentivar o meu ingresso na vida acadêmica;

- Aos meus amigos Lessa, Mariza, Maria Helena, Marcelo, Beto, Ana Maria, Luciana, Leninha, Iara, Gilda, José Odair, Cunha, Itamar, Ederson, Roberto, Francisco, Sérgio, Goes, Marilene, Pimentel, Amália, Alexandre, Carlos, Carlucho, Adonias, Irmegard, Maria Odete, Silvia, Vera Furlan, Elaine, Vera Gobo, Clarice e Ludovina, pelo incentivo, colaboração e agradável convivência;

- Ao amigo Claudio Costa pelo apoio na elaboração do Summary; 
- Ao amigo Hilkias pela digitação;

- À minha amiga Mônica Bertão pela atenção e apoio nas correções do original;

- Aos Professores do Departamento de Genética da ESALQ/USP pelos ensinamentos e apoio prestados, os quais contribuíram para minha formação;

- Aos funcionários do Departamento de Genética da ESALQ/USP, em especial a Silvana e o Fernando pela simpatia, colaboração e amizade;

- À todos os amigos próximos ou distantes, que sempre incentivaram-me a prosseguir,

- Ao Conselho Nacional de Desenvolvimento Científico e Tecnológico (CNPq) e à CAPES, pela concessão de Bolsa de Estudos. 


\section{SUMÁRIO}

Pág.

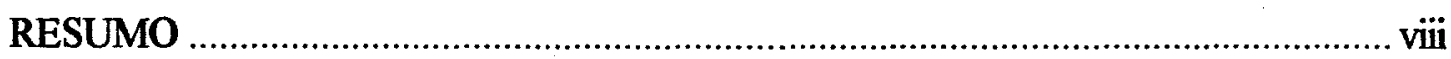

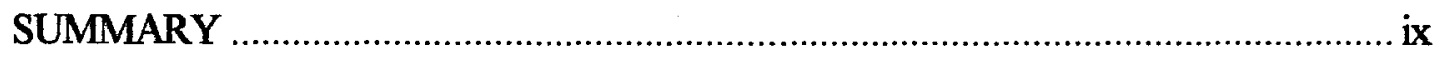

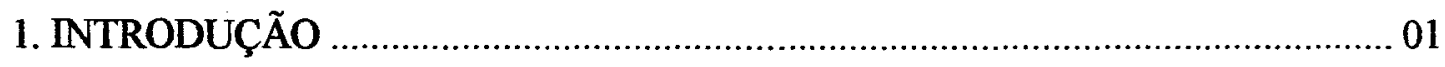

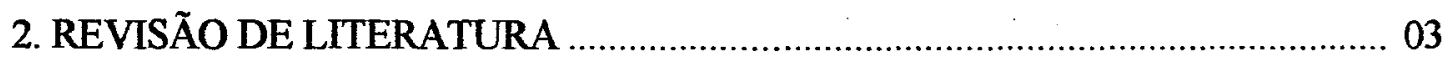

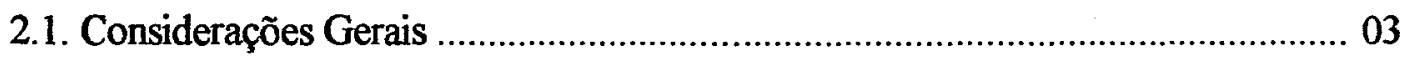

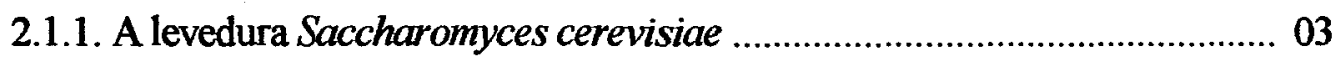

2.1.2. Herbicidas e leveduras ........................................................................... 04

2.2. Transferência de genes em leveduras ..................................................................... 05

2.2.1. Principais métodos de transformação …………………........................... 06

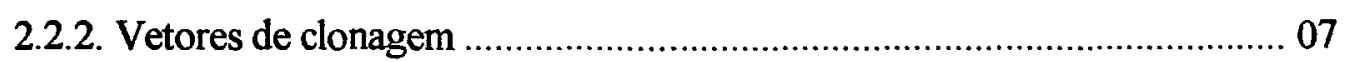

2.2.3. Importância da clonagem e transferência de genes em leveduras .............. 12

2.2.3.1. Expressão e secreção de peptídios heterólogos ............................ 12

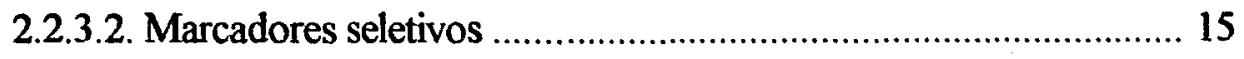

2.3. Separação de DNA cromossômico em gel de eletroforese .................................... 18

2.3.1. Eletroforese em campo pulsado (Pulsed Field Gel Electrophoresis) .......... 19

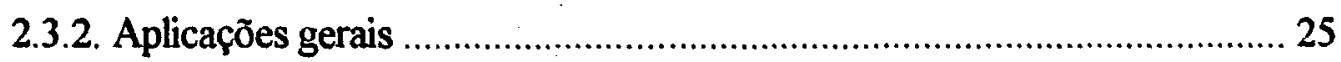

3. MATERIAIS E MÉTODOS …….................................................................... 30

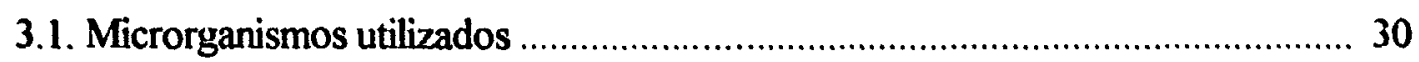




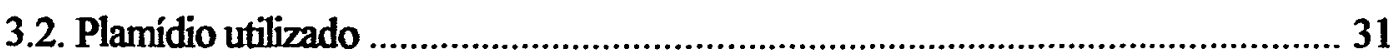

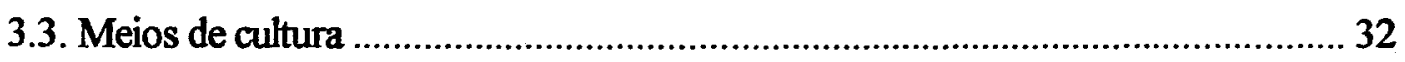

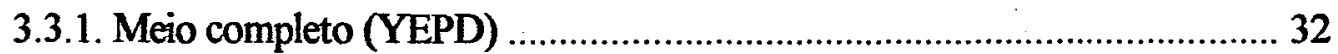

3.3.2. Meio de Luria e Bertani (MANIATIS etl., 1982) ……............................. 32

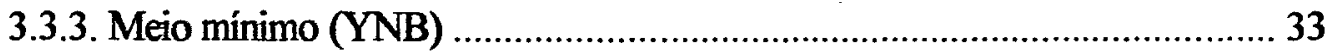

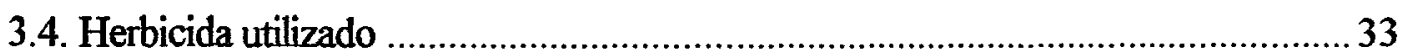

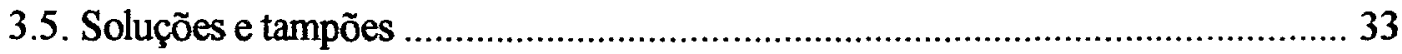

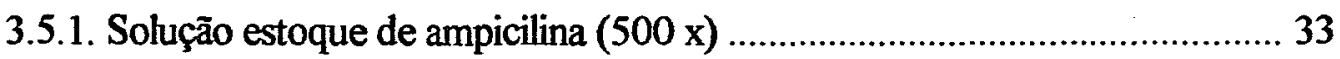

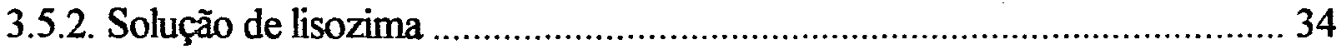

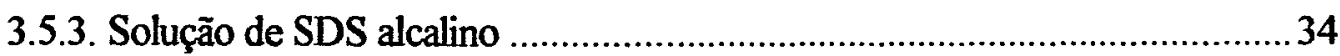

3.5.4. Solução de acetato de sódio ....................................................................... 34

3.5.5. Solução de X-Gal (5-Bromo-4-Chloro-3-indolyl-B-D galactosidase) …......35

3.5.6. Solução de IPTG (Isopropylthio-ß-D-galactoside) ................................... 35

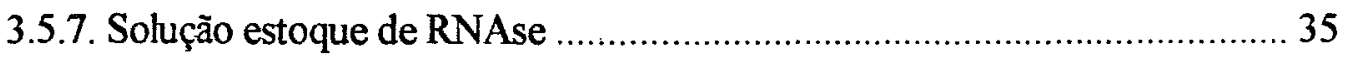

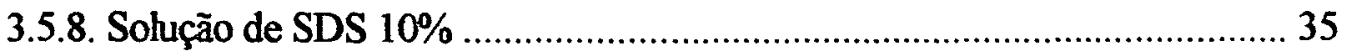

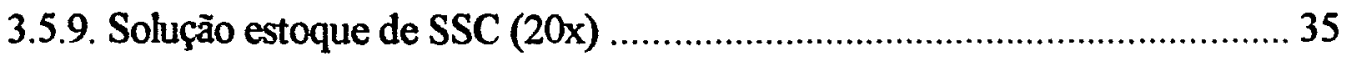

3.5.10. Solução de brometo de etídio (MANIATIS et al., 1982) .......................... 36

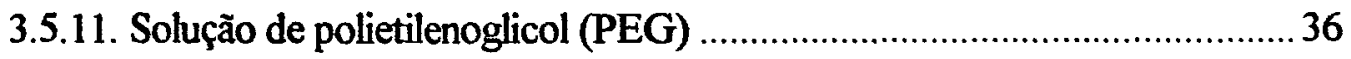

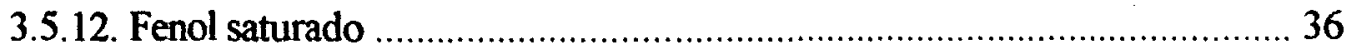

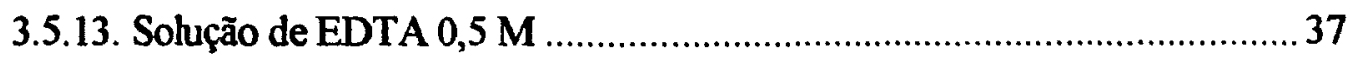

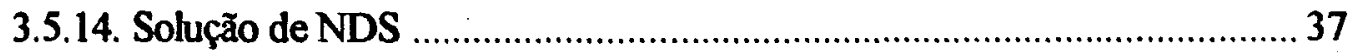

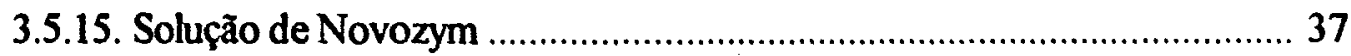




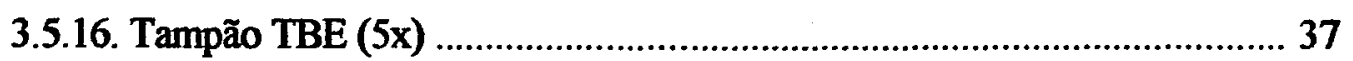

3.5.17. Tampão TE (MANIATIS et al., 1982) .................................................... 38

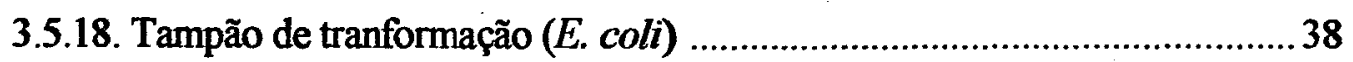

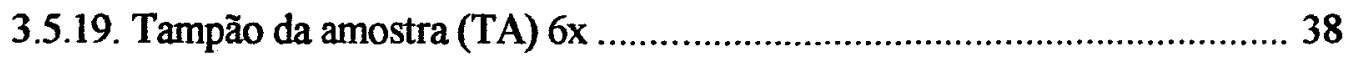

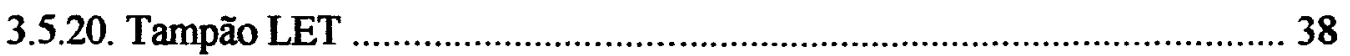

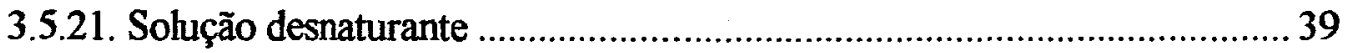

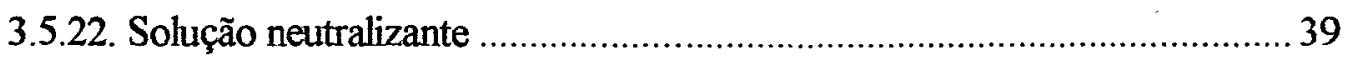

3.5.23. Solução de lavagem primária (hibridização) …………………………….. 39

3.5.24. Solução de lavagem secundária (hibridização) ……………………........ 39

3.6. Isolamento de DNA de leveduras com nitrogênio líquido .................................... 39

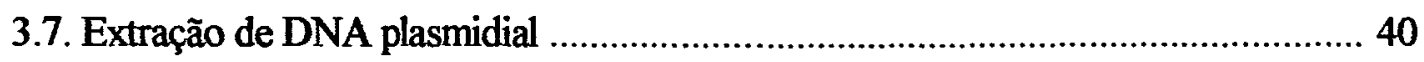

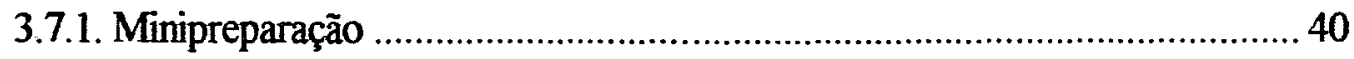

3.7.2. Determinação da concentração de DNA plasmidial ...................................... 41

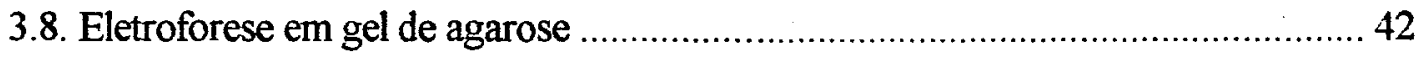

3.9. Digestão dos DNAs genômicos e plasmidiais com endonucleases de restrição .... 42

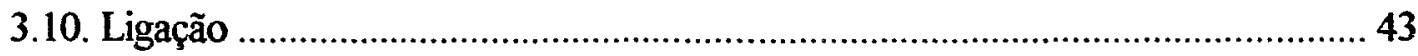

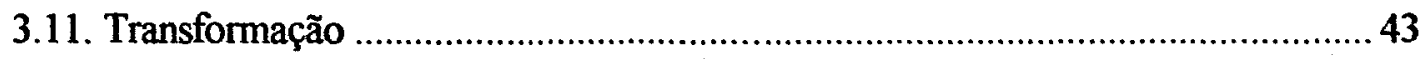

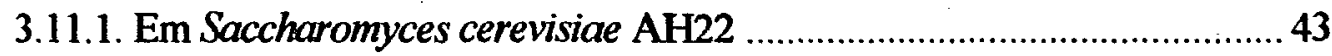

3.11.1.1. Método de IIMURA et al. (1983) ......................................... 43

3.11.1.2. Método de ITO et al. (1983) .............................................. 44

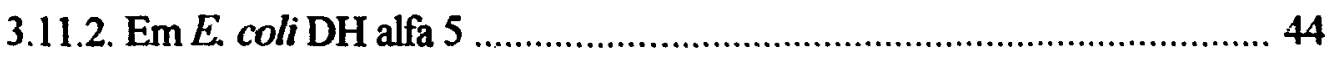

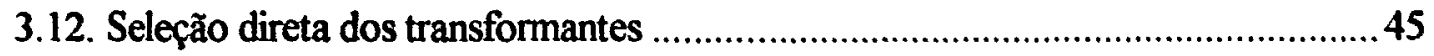

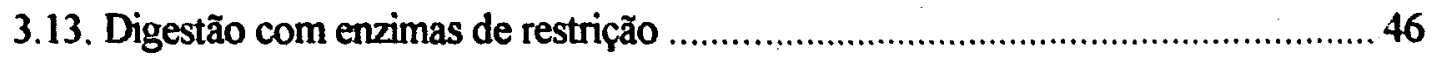


3.14. Determinação do grau de resistência dos clones .46

3.15. Avaliação da estabilidade mitótica dos plasmídios 46

3.16. Separação de DNA cromossômico de leveduras através da eletroforese em campo pulsado, pelo sistema CHEF

3.16.1. Preparação das amostras 47

3.16.1.1. Experimento 1 - Protocolo SCHWARTZ \& CANTOR (1984), modificado

3.16.1.2. Experimento 2 - Esferoplastização e desproteinização 48

3.16.1.3. Experimento 3 - Células intactas tratadas com detergentes e enzimas proteolíticas 48

3.16.1.4. Experimento 4 - Células intactas desproteinizadas 49

3.16.1.5. Experimento 5 - Células intactas tratadas com LiAc ou KAc desproteinizadas

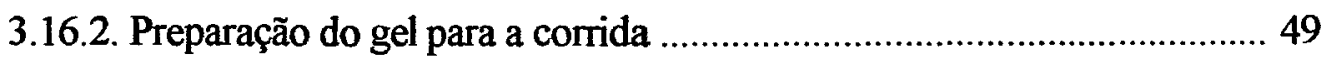

3.16.3. Preparação do aparelho (CHEF DR-II-BIO-RAD) ............................... 50

3.17. Eletroeluição em membrana diálise (MANIATIS et al., 1982) .......................... 50

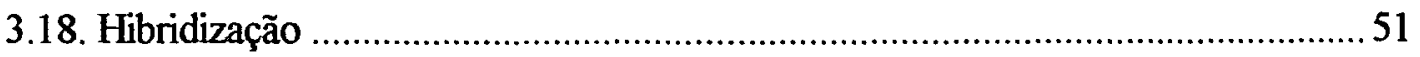

3.18.1. Preparação da membrana com manchas de DNA pontuadas ("Dot

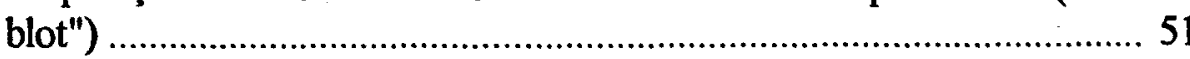

3.18.2. Pré-hibridização da membrana e preparação da sonda ........................... 51

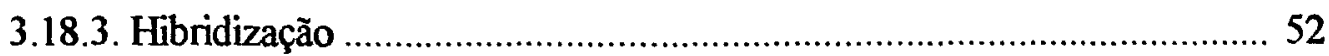

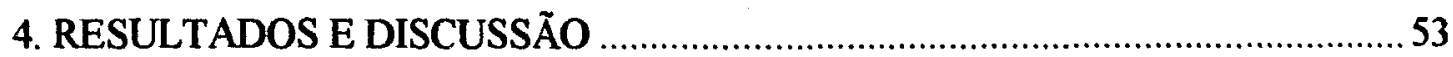

4.1. Clonagem do gene de resistência ao metolaclhor ...............................................53

4.2. Perfil eletroforético do plasmidio pMTC 15 ....................................................59 
4.3. Transformação de outras linhagens de $S$. cerevisiae ............................................ 60

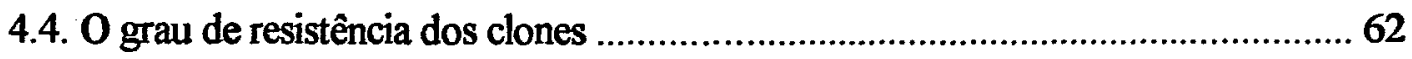

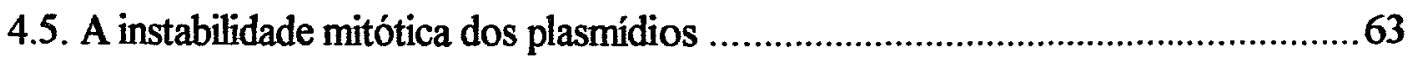

4.6. Experimentos realizados na separação de DNA cromossômico de leveduras em

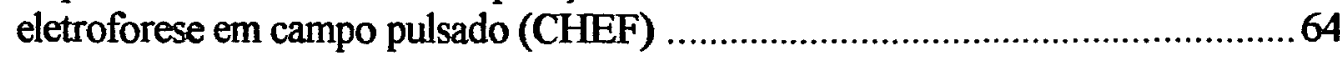

4.7. Localização do gene MTC 15 pela hibridização com DNA cromossomal através de eletroforese em campo pulsado 69

5. CONCLUSÃO 74 


\section{LISTA DE FIGURAS}

\section{Pág.}

Figura 1. Estrutura molecular do metolachlor 02

Figura 2. Plasmídio YEp 351 31

Figura 3. Eletroforese de DNA total dos clones de $S$. cerevisiae selecionados resistentes ao metolachlor. 1-10 clones recombinantes, 11 - $S$. cerevisiae AH22,12-linhagem resistente MD 3000, 13 - lambda/Hind III .... 56

Figura 4.1. Crescimento das linhagens de S. cerevisiae transformadas 58

Figura 4.2. Crescimento das linhagens de $E$. coli trasnformadas 58

Figura 5. Perfil eletroforético do plasmídio pMTC 15 59

Figura 6. Experimento realizados em eletroforese de campo pulsado (CHEF) com os cromossomos de S. cerevisiae MD 3000. Tempo de corrida totalizando 23h. 66

Figura 7. Eletroforese em campo pulsado de várias linhagens de S. cerevisiae. A) 1904; B) Fleischmann; C) M 300A; D) AH22; E) M 304-2C; F-G) MD 3000 (LIAC); I-J) MD 3000 (KAc). Tempo de corrida 24 horas

Figura 8. Autoradiografia resultante da hibridização do plasmídio pMTC 15 com o cromossomo XV de $S$. cerevisiae. A) MD 3000; B) AH22 R; C) AH22 s; D) M 3000; E) AH22 R

Figura 9. Autoradiografia resultante da hibridização do fragmento do pMTC 15 com os cromossomos XV e XIII/XVI da levedura $S$. cerevisiae. 1A) MD $3000 \mathrm{R}$ (XV); 1B) AH22 R (XV); 1C) AH22 R (XV); 1D) AH22 R (XII/XVI); 1E) M 300 A R (XV); 2A) M 300 2C R (XV); 2B) M 30A R (XV); 2C) MD 3000 (XV); 2D) MD 3000 (XIII/XVI); 2E) MD 3000 (XII/XVI); 2F) MD 3000 (XV); 2G) M 304-2C R (XII/XVI); 2H) AH22 R (XV); 2I) AH22 R (XIII/XVI); 2J) M 300A R (XV) 


\section{LISTA DE TABELAS}

Pág.

Tabela 1. Cariótipos eletroforéticos de leveduras determinados por eletroforese em campo pulsado

Tabela 2. Linhagens de Saccharomyces cerevisiae utilizadas nos processos de transformações e sua procedência 30

Tabela 3. Transformação de outras linhagens de $S$. cerevisiae usando $10 \mu \mathrm{g}$ de DNA do plasmídio pMTC 15

Tabela 4. Grau de resistência dos clones ao metolachlor. Crescimento em meio líquido. 63 


\title{
CLONAGEM E MAPEAMENTO MOLECULAR DO GENE DE RESISTÊNCIA AO METOLACHLOR EM Saccharomyces cerevisiae
}

\author{
Autora: NIRLEI APARECIDA SILVA \\ Orientador: FLÁVIO CESAR ALMEIDA TAVARES
}

\begin{abstract}
RESUMO
Este trabalho descreve a clonagem do gene de resistência ao metolachlor em um plasmídio epissomal bifuncional (YEp 351), o qual pode ser utilizado como marcador seletivo dominante na transformação de Saccharomyces cerevisiae. Clones tranformantes selecionados diretamente em meio YEPD acrescido de $720 \mathrm{mg} / \mathrm{L}$ de Metolachlor, tiveram seu DNA genômico extraído e utilizado para transformar Escherichia coli a fim de amplificar e recuperar os plasmídios recombinantes. Outras linhagens de Saccharomyces foram também transformadas e foi possível observar que existe diferença entre linhagens quanto às suas capacidades de receber, manter e expressar DNA heterólogo, pois houve variação considerável nas suas eficiências de transformação. Vários métodos foram aplicados para obtenção do "cariótipo eletroforético" (este termo refere-se ao genoma de um dado organismo expresso em bandas cromossômicas) de Saccharomyces cerevisiae, dentre eles, o tratamento com acetato de lítio ganhou mais destaque. Empregando-se a técnica de eletroforese em campo pulsado e hibridização, foi possível mapear o gene de resistência ao metolachlor no cromossomo XV da levedura, confirmando-se os dados de análise genética.
\end{abstract}




\title{
SUMMARY
}

\section{CLONING AND MOLECULAR MAPPING OF THE METOLACHLOR RESISTANCE GENE IN Saccharomyces cerevisiae}

\author{
Author:NIRLEI APARECIDA SILVA \\ Adviser: FLÁVIO CÉSAR ALMEIDA TAVARES
}

This work describes the cloning of the metolachlor resistance gene into an episomal bifunction plasmid (YEp 351) which can used as a dominant selective marker for Saccharomyces cerevisiae transformation. DNA of the transformed clones, directly selected onto YEPD medium added of $720 \mathrm{mg} / 1$ metolachlor, was used to transform Escherichia coli in order to amplify and recover recombinant plasmids. Other Saccharomyces strains were also transformed and as far as differences in receiving, mantaining and expression of the heterologous DNA is concerned, considerable variation in transformation was found them. Electrophoretic caryotyping (refers to an organism genome expressed in chromosomal bands) was perfomed in Saccharomyces cerevisiae accordind to different methods, and among them lithium acetate was the standing one. Pulsed field and hybridization were perfomed to map the metolachlor resistance gene into the yeast chromosome XV and these data were confirmed by genetical analysis. 


\section{INTRODUÇĀO}

Para a transformação em eucariotos, os plasmídios mais usados possuem marcadores auxotróficos, os quais complementam uma mutação auxotrófica na linhagem hospedeira. Porém, quando se trabalha com linhagens selvagens ou industriais, a maioria destes vetores não podem ser empregados, devido à ausência de marcas auxotróficas correspondentes nestas linhagens e também por apresentarem, com frequência, problemas relacionados à ploidia. Sendo assim, a utilização de marcadores dominantes nos plasmídios, usados como vetores de expressão, apesar de ainda trazerem alguns problemas referentes a transformação de leveduras, facilitam a seleção dos transformantes dispensando-se linhagens com marcas auxotróficas.

Além disso, a necessidade de testar novos marcadores de resistência dominante, deveu-se ao fato de que leveduras geralmente não são sensíveis a antibióticos comuns, portanto muitos sistemas baseados na resistência em $E$. coli não podem ser explorados nas transformações de leveduras.

O metolachlor (Figura 1) (2-cloro-n-2-etil-6-metifenil-n-2 metoxi-1metiletil) acetamina, é um herbicida pertencente ao grupo das cloroacetaminas, cujo modo de ação tem sido detectado sobre a atividade enzimática, como a síntese proteica, a respiração de plantas, assim como a inibição diferencial sobre o crescimento de leveduras do gênero Saccharomyces (DODGE, 1983; ECHEVERRIGARAY et al., 1991).

O presente trabalho teve como objetivos principais, clonar o gene dominante de resistência ao metolachlor, usá-lo como marcador seletivo nos processos de transformação de $S$. cerevisiae e realizar o mapeamento molecular do gene específico no genoma da levedura, através de eletroforese de campo pulsado e hibridização. 


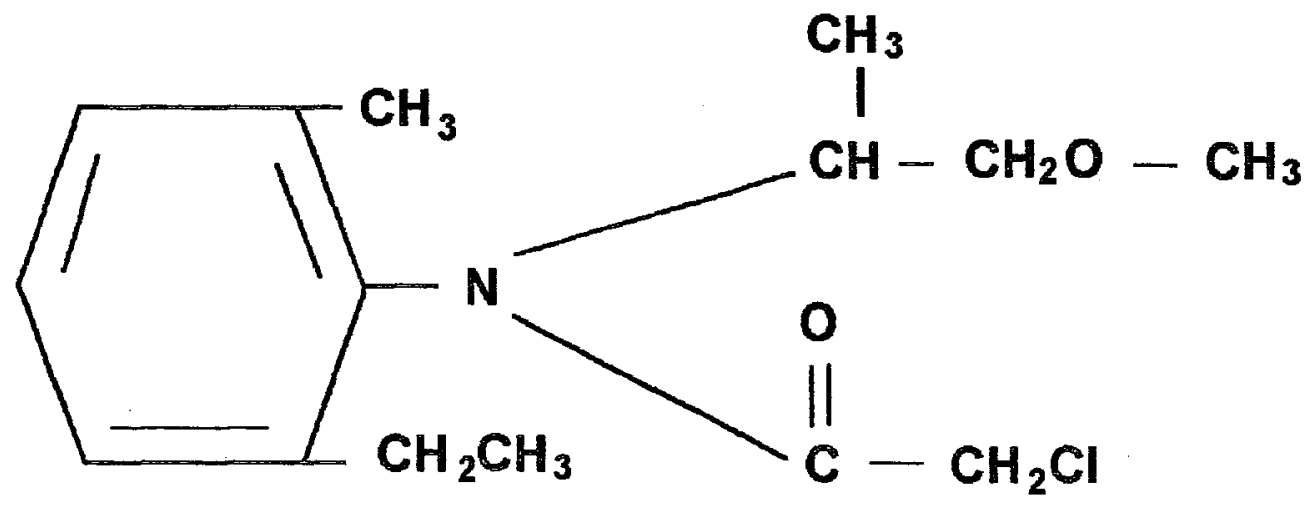

Figura 1. Estrutura molecular do metolachlor. 


\section{REVISÃO DE LITERATURA}

\subsection{Considerações Gerais}

\subsubsection{A levedura Saccharomyces cerevisiae}

O gênero Saccharomyces é classificado como um ascomiceto, caracterizado pela capacidade de formar esporos em ascos. É conceituado como microrganismo no qual a forma unicelular é predominante e pertence ao Reino Fungi (LODDER, 1970).

As leveduras têm se estabelecido como a maior classe de hospedeiros para clonagem e expressão de genes exógenos. $\mathbf{O}$ sucesso na exploração desses organismos deveu-se à combinação de atributos importantes: são organismos eucariotos; são formados por uma única célula que cresce rapidamente em meio simples, rendendo alta densidade celular; sua genética é a mais avançada devido à sua fácil manipulação e são hospedeiros apropriados para altos níveis de produção de proteínas secretoras (ROMANOS et al, 1992), por apresentarem atividades celulares associadas à secreção de proteínas e modificações nas atividades pós-transcricionais (HADFIELD et al., 1993).

$O$ recente e rápido avanço na genética molecular de leveduras deveu-se à transformação inicial de Saccharomyces cerevisiae usando plasmídio (BEGGS, 1978; HINNEN et al.; 1978; STRUHL et al., 1979), tornando possível aplicar a tecnologia de DNA recombinante nestes organismos. Desde então tem havido um avanço na expressão de genes clonados em Saccharomyces cerevisiae e em outras leveduras. Este fato tem permitido um melhor entendimento de seus componentes, resultando em novas escolhas de métodos e sistemas para propagação de DNA. 
Tais características têm feito da levedura Saccharomyces cerevisiae o organismo mais estudado e caracterizado dentre os microrganismos. Prova disso é a elaboração do seu mapa genético com 16 cromossomos metacêntricos com centenas de genes mapeados (MORTINER et al., 1992), o sequenciamento do cromossomo III por OLIVER et al. (1992) e a expectativa para o sequenciamento de todo seu genoma brevemente.

\subsubsection{Herbicidas e leveduras}

Os herbicidas são compostos inibidores de vias biossintéticas específicas, isto é, bloqueiam a síntese de carboidratos, lipídeos, aminoácidos, a síntese protéica e de DNA. Também são inibidores hormonais, cujos mecanismos primários de ação ainda permanecem pouco conhecidos (DODGE, 1983). Em certos casos o estudo dos mecanismos de ação tem levado à análise dos efeitos em organismos mais simples como bactérias, algas e leveduras (La ROSSA et al., 1984; ECHEVERRIGARRAY et al, 1991), o que propiciou avanços consideráveis nesta área. Os herbicidas também são utilizados como agentes seletivos no isolamento de mutantes, no mapeamento genético e na clonagem. A incorporação de resistência a herbicidas específicos por clonagem em plantas tem ampliado a própria aplicação destes.

Para o herbicida sulfometuron, foram obtidos mutantes em Saccharomyces cerevisiae e em Salmonella typhimurium, o que permitiu identificar seu efeito primário como sendo a inibição das isoenzimas II da acetolactato sintetase, envolvida no metabolismo da isoleucina e da valina (La ROSSA et al., 1984; FALCON \& DUMAS, 1985).

Estudos de sequenciamento feitos por CASEY et al. (1988) demonstraram que os alelos são idênticos exceto a mutação de um nucleotídeo (uma citosina para uma timina), a qual resulta na troca de uma prolina pela serina, cuja permuta confere resistência à inibição de sulfometuron. A resistência ao sulfometuron constituiu-se, junto 
com o gene NPT II (Neomicina fosfotransferase II - de origem bacteriana), nos genes clonados mais utilizados na seleção positiva de transformantes em linhagens não marcadas de leveduras.

Quatorze herbicidas comercializados no Brasil foram avaliados quanto ao efeito sobre leveduras, verificando-se que nove causaram a inibição do seu crescimento em concentrações elevadas. Dentre os herbicidas identificados como inibidores, o metolachlor, vem sendo o mais estudado com vários mutantes resistentes caracaterizados e mapeados (ECHEVERRIGARAY et al., 1991). Assim, Os herbicidas por afetarem o metabolismo de leveduras, surgem como importantes recursos para o estudo de outras propriedades fisiologicas.

\subsection{Transferência de genes em leveduras}

Para a transferência de material genético, várias técnicas envolvem cruzamento naturais ou artificiais, sendo que estes últimos, em leveduras, podem ser feitos por fusão de protoplastos ou transformação genética por DNA extracelular. A introdução de DNA estranho em uma célula hospedeira que pode ser um microrganismo ou célula de planta, tornou-se possível com a utilização de plasmídios, cosmídios ou fagos como veículos de clonagem. Dois fatos contribuíram para este desenvolvimento: a obtenção de protoplastos e a descoberta de endonucleases de restrição, os quais clivam o DNA em sítios específicos (HADFIELD et al., 1993).

Estes eventos marcaram o início da tecnologia do DNA recombinante contribuindo para a evolução da biologia molecular e em especial para a compreensão da estrutura do genoma de muitos organismos. Além disso, tal metodologia permite a recombinação genética de espécies distintas o que seria impossível de ser realizado naturalmente. 


\subsubsection{Principais métodos de transformação}

O primeiro método empregado na transformação de $S$. cerevisiae envolveu remoção enzimática da parede celular para produzir esferoplastos, seguida da adição de polietilenoglicol (PEG) (HINNEN et al., 1978; BEGGS, 1978; STRUHL et al., 1979). A regeneração da parede celular é promovida na presença de cloreto de cálcio (IIMURA et al., 1983).

BEGGS (1978) e STRUHL et al. (1979) desenvolveram algumas combinações entre vetores e linhagens receptoras dando melhor eficiência de transformação.

De acordo com HARASHIMA et al., (1984), a obtenção de esferoplastos é essencial para a introdução de DNA. Porém ITO et al. (1983) demonstraram, como segundo método que células intactas podem ser transformadas por DNA plasmidial. Este é um processo multifásico que depende da aquisição de competência da célula ao nível de parede celular (BRZOBOHATY \& KOVAC, 1986). Este método tem sido muito usado, apesar da desvantagem da baixa eficiência de transformação, quando comparado aos que utilizam esferoplastos.

As razões pelas quais o cátion lítio favorece a entrada de DNA nas células de levedura não estão bem conhecidas, embora tenha sido evidenciado que ele exerce um efeito permeabilizante na parede celular da levedura (BRZOBOHATY \& KOVAC, 1986). Modificações neste método alcalino, foram realizadas por GIETZ \& SCHIESTIL (1991) produzindo alta eficiência na transformação.

Um terceiro método tem sido utilizado com o intuito de aumentar a eficiência de transformação. São os métodos físicos, onde encontra-se principalmente a eletroporação, que foi inicialmente divulgada por NEUMANN et al. (1982). A introdução de DNA plasmidial e subsequente transformação foram obtidas pela aplicação de pulsos elétricos nas células de mamíferos. Este método tem sido frequentemente usado 
nos processos de transformação, incluindo protoplastos de leveduras (HIGGNS \& STRATHERN, 1991).

Utilizando a técnica de eletroporação, BERGKAMP et al. (1993) transformaram K.marxianus restabelecendo auxotrofia para síntese de uracila, para posterior mapeamento desta sequência no genoma da espécie.

Não é necessário retirar toda a parede celular para a competência da eletroporação. Porém, com maior tempo de digestão, obtém-se melhores resultados. A esferoplastização parcial ainda requer suporte osmótico para manter a integridade e viabilidade celular (EUERETT et al., 1992; KASUSKE et al., 1992).

KASUSKE et al. (1992) utilizaram o mesmo método para introduzir DNA plasmidial em células intactas de leveduras. Neste último procedimento foi obtida a mais baixa eficiência de transformantes, comparado aos métodos precedidos de esferoplastização e métodos químicos.

O tipo de aparato de eletroporação não influencia na eficiência da transformação (KASUSE et al., 1992), apenas alguns parâmetros como voltagem, força de duração do pulso elétrico, concentração de DNA, número de células e o estágio de crescimento, devem ser estabelecidos para render mais transformantes em $S$. cerevisiae (MEILHOC et al., 1990)

A vantagem deste método é de ser rápido e efetivo (EUERETT et al., 1992), podendo gerar transformantes em 30 minutos aproximadamente (HIGGNS \& STRATHERN, 1991).

\subsubsection{Vetores de clonagem}

Os vetores de clonagem assumem um papel muito importante nos processos de transformaçōes de leveduras e outros organismos. Para tal evento, os plasmídios bifuncionais são os mais efetivos, pois facilitam sua amplificação, recuperação e caracterização sendo propagados em levedura e $E$. coli (KNOWLTON, 
1986). Tais vetores de acordo com sua interação com a célula hospedeira são classificados em replicativos (YRp), integrativos (YIp), epissomais (YEp) e cromossomos artificiais (YAc).

Os vetores replicativos (YRp) são assim chamados por incluirem um elemento conhecido como a sequência de replicação autônoma (ARS). Tais sequências são segmentos de DNA cromossonal, os quais são presumíveis replicons. Foram isolados ARSs de mitocôndrias (HYMAN et al., 1982) e de outros genomas eucarióticos (STINCHCOMB et al., 1979). Estes plasmídios apresentam-se como moléculas circulares de DNA extracromossonal, presentes no núcleo, sendo sua replicação controlada pelos produtos gênicos necessários à duplicação do DNA cromossonal.

Os elementos ARS são importantes no desenvolvimento de sistemas de transformação, pois conferem altas frequências de transformação em $S$. cerevisiae (MARUNOUCHI et al., 1987). Mas apresentam desvantagens quanto a sua estabilidade mitótica (MURRAY \& SZOSTAK, 1983). A segregação do plasmídio ARS é preferencial sendo que a célula filha perde 20 vezes mais o plasmídio que uma célula mãe. Esta assimetria na divisão celular pode esclarecer a multiplicidade de cópias destes plasmídios encontrados em algumas células (ZAKIAN \& KUPFER, 1982).

Por se inserirem no DNA cromossômico os plasmídios (YIp) são conhecidos como integrativos (SCHERER \& DAVIS, 1979). Apesar da desvantagem quanto a sua difícil recuperação, os vetores integrativos após o isolamento do DNA cromossomal da levedura, seguido pela digestão com enzimas de restrição e ligação, podem resultar em DNA circular e serem recuperados. Para tanto, sua estrutura integrada terá que conter origem de replicação e marcadores seletivos para serem selecionados em $E$. coli (WINNACKER, 1987).

Sua vantagem, porém, está na baixa instabilidade mitótica. $O$ número de cópias é geralmente um por célula, podendo ser aumentado por amplificação gênica. Quando altas concentraçōes de vetores integrativos são usados em transformaçōes, podese obter a inserção de multicópias em tandem, presumivelmente devido a repetidos 
eventos de recombinação. Integrantes de múltiplas cópias são relativamente estáveis e têm sido aplicados, em estudos de dosagem gênica (ORR-WEAVER \& SZOZTAK, 1983).

Os vetores epissomais (YEp) são bastante utilizados na transformação genética de leveduras para expressão de genes heterólogos. Estes plasmídios, encontrados na maioria das linhagens de $S$. cerevisiae, numa média de 55-100 cópias por célula haplóide, utilizam o sistema de replicação do plasmídio endógeno $2 \mu \mathrm{m}$. LIVINGSTON (1977), através da análise de tétrades obtida de um cruzamento entre linhagens contendo os plasmídios (cir + ) com linhagens sem plasmídios (cir0), observou que todas as células haplóides em um asco contém plasmídios $2 \mu \mathrm{m}$.

Alguns parâmetros como a estabilidade do plasmídio, o número de cópias destes, o marcador seletivo e as condições de crescimento são muito importantes para produzir altos níveis de expressões gênicas (VAN DER AAR et al., 1992).

O maior problema da utilização de organismos melhorados em escala industrial é a manutenção da estabilidade genética destes. A instabilidade pode ser estrutural ou segregacional.

A instabilidade estrutural está relacionada a problemas pouco frequentes, como deleções, inserções, rearranjos, mutação de ponto, etc., os quais reduzem ou eliminam a expressão dos genes específicos (MIZUKAMI et al., 1986). Tais problemas não foram contornados porque pouco se sabe sobre as causas para que tal fenômeno ocorra.

A instabilidade segregacional resulta porque os vetores mais utilizados nos processos de transformação são os epissomais de replicação autônoma, os quais apesar de exibirem altas frequências de transformantes (MARUNOUCHI et al., 1987), tem a desvantagem de perder seus plasmídios durante as gerações sucessivas (MURRAY \& SZOSTAK, 1983). 
Uma maneira de amenizar a perda do plasmídio é utilizar um meio seletivo definido como antibióticos (LONGO, 1993), herbicidas (FALCO \& DUMAS, 1985; LaROSSA \& SCHLOSS, 1984), aminoácidos e outros componentes.

A estabilidade dos plasmídios é muito complexa, pois depende de condições fisiológicas específicas e de interação plasmídio/hospedeiro (BUJEGA et al., 1989). Além disso, outros meios podem manter plasmídios mais estáveis na célula. Vetores ARS podem ser estabilizados pela adição de uma sequência centromérica de levedura (CEN), oferecendo maior estabilidade mitótica, reduzindo a perda para 1 a $2 \%$ por divisão (CLARKE \& CARBON, 1980).

Com o intuito de sanar o problema da instabilidade dos plasmídios recombinantes, o telômero, que é uma estrutura essencial à estabilidade e replicação dos cromossomos, tem sido incorporado aos plasmídios. Porém esse subsídio adicional não confere estabilidade se o tamanho da molécula for inferior a $50 \mathrm{~Kb}$ (SZOSTAK \& BLACKBURN, 1984). Entretanto, um cromossomo artifical foi construído por BURKE et al. (1987), sendo este capaz de clonar um fragmento de DNA exógeno com centenas de kilobases e mantê-lo estável em $S$. cerevisiae.

Os cromossomos artificiais (YAc) contendo centrômeros e telômeros são mantidos em cópia única e têm sido utilizados apenas para a compreensão do processo de replicação e segregação dos cromossomos de eucariotos.

A eficiência da transformação é também influênciada pelo tipo e conformação do plasmídio. É sabido que os plasmídios integrativos transformam seus hospedeiros com baixa eficiência, comparados com moléculas de replicação autônoma (1 transf./ $\mu \mathrm{g}$ de DNA plasmidial), (BEGGS, 1978; GALLEGO et al., 1993), porém quando estes são linearizados produzem maior número de transformantes.

KASUSKE et al. (1992) demonstraram que a conformação do plasmídio favorece o processo de transformação. Utilizando um plasmídio circular e um linear integrativo, detectou-se que quando usados separadamente os plasmfdios lineares integrativos rendiam mais transformantes de Candida maltosa, isto porque mais de uma 
molécula linear eram carregadas para dentro da célula facilitando o evento de recombinação. VIDAL \& GARBER (1994), confirmaram que a eficiência foi 100 vezes maior quando os plasmídios integrativos foram linearizados comparado com experimento usando plasmídios circulares (HIEP et al., 1993).

A concentração de células receptoras e a concentração do DNA plasmidial usada no processo de transformação devem ser bem estabelecidas para melhorar também a eficiência da transformação. Altas concentrações de DNA plasmidial podem ter um efeito negativo neste processo (KASUSKE et al., 1992).

Quanto a sua importância ambos os vetores são interessantes. O integrativo para manter a estabilidade e o replicativo para aumentar o número de cópias de um cassete de expressão ou gene (SANGLARD \& FIECHTER, 1992).

Outros vetores tem sido desenvolvido, com o objetivo de aumentar os níveis de expressão de proteínas heterólogas de interesse médico e industrial. São os vetores de expressão e de secreção (ELLIOT, 1988). Tais vetores possuem elementos necessários à transformação, replicação e manutenção no organismo hospedeiro, tais como: um cassete de expressão que consiste em elementos essenciais para o controle transcricional e sequências promotoras e terminadoras que flanqueiam a região codificada do gene de interesse. A diferença entre eles é que o vetor de secreção inclui um elemento adicional, o peptídio sinal, o qual é responsável pelo direcionamento da proteína na via secretora até a superfície celular.

Como vimos, inúmeros são os vetores utilizados nos diversos sistemas de transformações de muitos organismos. Estratégias variadas são empregadas para obter altos níveis de expressão de proteínas importantes. Entretanto não há um organismo ou sistema de transformação modelo que tenha aplicação universal adequada a todos os trabalhos. 


\subsubsection{Importância da clonagem e transferência de genes em leveduras}

\subsubsection{Expressão e secreção de peptídios heterólogos}

Devido a sua condição de organismo eucarioto, dispondo do sistema enzimático para o processamento pós-traducional e secreção das proteínas, as leveduras ocupam posição de destaque como hospedeiros de genes heterólogos. Empregando tais organismos tem sido possível obter vários produtos gênicos de eucariotos superiores com importância econômica. Para obter êxito na produção desses componentes, é necessário obter o gene responsável pela síntese do produto desejado e inseri-lo num vetor adequado, o qual deverá conter sequências promotoras e terminadoras para viabilizar a transcrição e tradução do mesmo. Dependendo da proteína, o vetor deverá incluir também um peptídio sinal e modificações pós traducionais para garantir a secreção do peptídio.

Em sua revisão ROMANOS et al. (1992) descreve passo a passo, como ocorre a expressão de gene exógeno em leveduras.

Vários exemplos poderiam ser citados do emprego de leveduras na expressão de genes de interesse.

Utilizando o promotor e o peptídio sinal da invertase codificada pelo gene suc2, NISHIZAWA et al. (1989) obtiveram a expressão do gene da amilase de ratos em S. cerevisiae.

JANG et al. (1990) usando um plasmídio multicópias, estudou o caráter regulatório do gene $s u c 2$ da invertase. Os resultados evidenciaram que sob condições anaeróbicas houve maior produção de invertase e etanol, mas uma menor geração de biomassa que em condições aeróbicas.

Níveis consideráveis de expressão de proteínas heterólogas foram obtidos em leveduras (VARONI \& LOTTI, 1989), utilizando-se vetores epissomais baseados no $2 \mu \mathrm{m}$, portadores de uma sequência UAS-GAL ligada a diferentes promotores TATA 
box. Altos níveis de expressão foram obtidos com diferentes proteínas como betagalactosidase de $K$. lactis e alfa-glucoamilase de $S$. diastalicus. Os mais altos níveis de produtividade foram obtidos durante a fase inicial do crescimento (PORRO et al., 1991).

Outras substâncias de interesse comercial têm sido produzidas através de plasmídios quiméricos que se expressam em leveduras. Uma delas é a equistatina, um polipeptídio de 49 aminoácidos isolado do veneno de Echis carinatus, que inibe a agregação de plaquetas por bloquear um receptor de fibrinogênio. CARTY et al. (1990) produziram uma equistatina recombinante, a qual é secretada em $S$. cerevisiae, não ocorrendo o mesmo em $E$. coli.

Outras leveduras como Kluyveromyces, Pichia e Hansenula, apresentam propriedades equivalentes a Saccharomyces cerevisiae quanto ao crescimento mas são melhores secretoras de proteínas (RIETVELD et al., 1988; ROMANOS et al., 1992; GELLINSEN et al., 1990).

O problema de baixa concentração de proteínas exportadas pode ser o resultado da rigidez da parede celular de $\boldsymbol{S}$. cerevisiae. Com isso, muitos peptídios heterólogos, principalmente os de alto peso molecular, que seriam secretados ficam no espaço periplasmático exigindo processos especiais para recuperação dos mesmos.

A levedura Kluyveromyces lactis a vários anos vem sendo empregada comercialmente para a produção de lactase (B-galactosidase). Utilizando um vetor contendo elementos regulatórios do gene da lactase, RIETVELD et al. (1988) verificaram que $K$. lactis tem propriedades superiores a $S$. cerevisiae para a produção intra e extracelular de proteínas heterólogas.

Devido a sua facilidade em secretar proteínas a linhagem de Kluyveromyces marxianus tem sido utilizada como hospedeira de genes interespecíficos e intergenéricos (BERGKAMP et al., 1992).

BERGKAMP et al. (1992) demonstraram que a levedura $K$. marxianus $e$ uma excelente receptora de genes de $S$. cerevisiae, como leu2 e ura3, sugerindo sua utilização para produção de proteínas heterólogas nas indústrias de alimentos. 
Linhagens de Candida albicans também são útilizadas como hospedeiros de genes heterólogos. Esta espécie possui morfologias distintas (leveduriforme e micelial), onde esta última, é frequentemente patogênica ao homem devido à secreção de algumas proteínas extracelulares. NIETO et al. (1993) restauraram a mutação sec18 em S. cerevisiae usando o clone contendo o gene sec18 de Candida albicans e demonstraram assim que linhagens recombinantes podem expressar e secretar proteínas de interesse da levedura Candida albicans.

O gênero Pichia também inclui-se entre as leveduras capazes de receber, manter e expressar DNA de outro organismo (ROMANOS et al., 1992). Um mecanismo adicional de integração preferencial de DNA não homólogo tem rendido a estes organismos um estudo mais aprimorado de novos sistemas de tranformação. HIEP et al. (1993) utilizaram como indicadores genéticos para transformar linhagens de Pichia os genes heterólogos leu2 e ade2 de S. cerevisiae e o gene homólogo de Pichia, ade1. Observou-se, neste caso, a desrupção do gene adel no cromossomo da levedura pela inserção do gene leu2 de $S$. cerevisiae. Esta integração garantiu a estabilidade do gene em questão.

Um sistema de expressão heteróloga muito importante foi desenvolvido em Hansenula polimorpha. Esta levedura entre outras espécies são capazes de utilizar metanol como fonte de energia, e sua adição no meio de cultura induz as enzimas envolvidas no metabolismo do metanol e também o aparecimento de peroxissomos. Para a produção do antígeno de superfície da hepatite $B$, foi necessário construir uma série de vetores de expressão/integração, utilizando duas enzimas do metabolismo clonadas [metanol oxidase (MOX) e formato desidrogenase (FMD)] e um promotor-induzível (GELLINSEN et al., 1990).

É importante ressaltar aqui que a aplicação da biotecnologia tem assumido um papel efetivo tornando-se um recurso adicional para melhorar a produtividade de muitos organismos, o que seria inviável somente utilizando os métodos convencionais. 


\subsubsection{Marcadores seletivos}

Para seleção de células transformantes de leveduras a complementação de marcas auxotróficas tem sido utilizada. Em princípio, todos genes para os quais há uma mutação disponível podem ser usados como marcadores seletivos. O primeiro gene a ser descrito foi da leu2, empregados nos experimentos de HINNEN et al. (1978). Para isolar tipos específicos de mutantes auxotróficos de leveduras, uma série de métodos para seleção positiva e enriquecimento de meios de cultura têm sido descritos (BOEKE et al., 1984). Entretanto, alguns destes sistemas podem ser facilmente obtidos pelo uso eficiente de métodos de seleção direta (TAVARES, 1989).

Células intactas de leveduras auxotróficas para o gene trp1, foram transformadas, com o plasmídio YRp7 utilizando o tratamento com LiAc (ITO et al., 1983).

O método de seleção usando marcadores auxotróficos vem sendo muito usado, porém somente mostra ser viável em leveduras haplóides. É difícil usar esse método em linhagens industriais, através da indução da auxotrofia poderá ocorrer mudança na constituição genética da linhagem e também em suas características, o que não é interessante. Além do mais, a maioria das linhagens são aneuplóides ou poliplóides, tornando o isolamento de mutantes quase impossível (CASEY et al., 1988).

Um recurso com o intuito de melhorar linhagens industriais é a introdução discreta de fragmentos de DNA exógeno, via transformação, usando para isso um marcador dominante para garantir com sucesso a detecção dos transformantes.

Um dos primeiros marcadores dominantes a ser reportado em leveduras foi a resistência ao antibiótico aminoglicosídio G418, uma forma da gentomicina. Uma vez que a maioria das leveduras são sensíveis para o antibiótico, o marcador resistente aminoglicosídio G418, que é codificado pelo transposon Tn 903 de $E$. coli, pode ser efetivamente usado para seleção de transformantes (JIMENEZ \& DAVIS, 1980). A eficiência deste determinante foi otimizada por WEBSTER \& DICKSON (1983). O uso 
de glicerol substituindo a glicose como fonte de carbono durante a seleção reduz o aparecimento de colônias mutantes resistentes a G418 não transformadas.

Dando continuidade aos estudos com G418, HADFIELD et al. (1990) isolaram sequências codificadoras do aminoglicosídio transferase (APT) do Tn 903 e incorporaram-na para construção do gene heterólogo, usando $p g k l$ como promotor e terminador. $\mathrm{O}$ apt heterólogo apresentou-se como determinante de resistência em leveduras.

Outros marcadores resistentes a antobióticos tem sido usados com sucesso em leveduras. GRITZ \& DAVIS (1983) reportaram a expressão da resistência à higromicina B em $S$. cerevisiae. Posteriormente, um plasmídio bifuncional com a mesmas características foi construído por KASTER et al. (1984).

Novos tipos de plasmídios seletivos tem sido construído promovendo resultados em várias linhagens de $S$. cerevisiae. Dentre eles estão os plasmídios que codificam a resistência para clorofenicol (HADFIELD et al., 1987), fleomicina (GATINOL et al., 1990) e nistatina (LONGO, 1991).

O plasmídio que confere resistência ao clorofenicol é bifuncional podendo se expressar em leveduras e $E$. coli. Este gene é heterólogo contendo o promotor de leveduras adcl modificado, teminador $c y c l$ (citocromol) e sequência codificadora cat (clorofenicol acetil tranferase) do Tn9. A resistência ao antibiótico é codificada por 3 genes ble, um é do transposon Tn5 (MAZODIER et al., 1985), outro do plasmídio pUB1 10 de Staphylococcus (SEMON et al., 1987) e um terceiro (Sh ble) que foi clonado de uma linhagem produtora da talisomicina de Streptoalloteihus hindustanus (DROCOURT et al., 1990). Tais genes conferem resistência em $E$. coli para bleomicina e fleomicina, sendo que esta última atua nas células de procariotos e eucariotos provocando quebra da molécula de DNA.

Utilizando vetores do gene $c y c l$, a resistência codificada pelo transposon Tn5 tem sido expressada $S$. cerevisiae. Com o uso de promotores fortes os níveis de 
resistência e a eficiência da transformação tem sido melhorados (GATINOL et al., 1990).

A nistatina é um antibiótico frequentemente utilizado no enriquecimento de mutantes de leveduras e no isolamento de mutantes resistentes, sendo um antibiótico efetivo contra fungos. Ele atua nas células causando rompimento e perda do conteúdo citoplamático, através de um desbalanço no transporte de cátions e pela combinação com esteróis da membrana celular (TAVARES, 1992). Dados obtidos sugerem que o gene de resistência à nistatina constitui-se numa alternativa na construção de vetores plasmidiais com marcas dominantes (LONGO, 1991).

Genes de resistência a metais pesados têm sido usados em transformações, sendo o mais empregado o gene da resistência ao cobre, denominado cup1, que foi clonado e caracterizado por FOGEL \& WELCH (1982). A resistência ao cobre em leveduras é conferida por múltiplas cópias do gene cupl, o qual pode ser usado como um marcador dominante em linhagens sensíveis. Vetores de expressão bifuncionais estão sendo construídos por MACREEDIE et al. (1989), o quais contém os cassetes de expressão ao cobre.

Segundo REISER et al. (1990) os genes de amilases quando clonados, permitem sua transferência e expressão em linhagens sensíveis. Este dado é muito importante, pois oferece recursos para contornar a deficiência de muitas espécies de Saccharomyces quanto ao aproveitamento do amido como fonte de carbono.

0 gene mell que confere a produção de alfa-galactosidase de $S$. cerevisiae, foi clonado por RUOHOLA et al. (1986) para estudar sua expressão num plasmídio multicópias. Parece que o alto número de cópias do gene mell não eleva a produção de alfa-galactosidase. GENDRE \& GUERINEAU (1986) construiram um vetor contendo os genes mell e G418 como marcadores seletivos e com isso a eficiência de transformação foi aumentada.

Genes de resistência a herbicidas também têm tido sucesso na transformação de leveduras. CASEY et al. (1988) utilizaram o gene de resistência ao 
sulfometuron metil (SM) como marcador dominante em vetores replicativos e integrativos em linhagens industriais Saccharomyces sp.

Vetores plasmidiais que conferem resistência ao glifosato, foram construidos por KUNZE et al. (1989). O seu modo de ação inclui a inibição de uma enzima que catalisa a conversão do sikimato-3-fosfato a 5-enolsikimato-3-fosfato (EPSP sintetase). $O$ gene que codifica para EPSP sintetase tem sido clonado em $S$. cerevisiae e $E$. coli. Glifosfato (n-fosforometil-glicina) inibe tanto o crescimento de plantas quanto o crescimento de bactérias e leveduras (ECHEVERIGARAY et al., 1991).

A alta eficiência do glifosato como marcador seletivo no processo de transformação possibilita a aplicação deste gene de resistência como marcador dominante.

A utilização de marcadores dominantes são convenientes porque aumentam a variedade de linhagens hospedeiras que podem ser testadas, incluindo linhagens de $S$. cerevisiae industriais e prototróficas, tornando-se num instrumento interessante para o melhoramento genético de vários organismos. Este novo recurso oferece um método de seleção alternativo, usando meios enriquecidos para o isolamento de transformantes (ROMANOS et al., 1992).

\subsection{Separação de cromossomos em gel de eletroforese}

Com recursos de microscopia pouco pode ser realizado quanto ao conhecimento do cariótipo de microrganismos. Apesar disso, vários trabalhos relevantes foram realizados (MATILDE et al., 1969). O mapeamento genético, embora forneça elementos importantes para o conhecimento de grupos de ligação, não fornece informações quanto a constituição física dos cromossomos. Em muitos organismos este mapeamento não pode ser feito devido a dificuldade de se obter mutaçðes especificas, uma vez qua a maioria dos organismos de interesse não apresentaram ciclo sexual e são geralmente aneuplóides ou poliploides (MILLS \& Mc CLUSKEY, 1990). 
A separação de cromossomos em gel de eletroforese embora não chegue a contornar tais problemas está possibilitando obter outras informações sobre o genoma, ampliando assim, o conhecimento sobre a genética de vários fungos.

\subsubsection{Eletroforese em campo pulsado (Pulsed Field Gel Electrophoresis)}

$\mathrm{Na}$ análise de amostras de DNA a separação de fragmentos grandes fica impossibilitada quando estes são maiores que $60 \mathrm{~Kb}$ (MANIATIS et al., 1982). Acima deste limite os fragmentos migram juntos no gel (CHU et al., 1986). Estudando o problema da co-migração da molécula no gel, SCHWARTZ et al (1982) propuseram que se dois pulsos elétricos fossem aplicados alternadamente no gel, seria possível mobilizar grandes moléculas independentemente do tamanho e separá-las de acordo com seu peso molecular (SCHWARTZ \& CANTOR, 1984).

Várias técnicas vem sendo utilizadas para separação de DNA cromossomal íntegro e determinação do seu peso molecular. Elas consistem basicamente na introdução de células intactas em uma matriz de agarose com concentração definida, na presença de tampão específico e submetidas a um campo elétrico alternado. Tendo já estabelecidos alguns parâmetros, tais como, tempo de corrida, pulsos, tempo de duração dos pulsos, temperatura e voltagem, como resultado desta corrida tem-se o genoma do organismo visualizado como bandas distintas (SKINNER et al., 1991).

A resolução do perfil eletroforético ocorre quando um campo elétrico é aplicado no gel. Nesse momento as moléculas de DNA elongam-se na direção do campo e migram no gel. Após a remoção do primeiro campo elétrico, um segundo campo elétrico é então ativado, sendo que neste o DNA em espiral pode alterar sua conformação, reorientar-se e migrar em direção a este campo. $O$ tempo de reorientação e alinhamento de grandes e pequenas moléculas é diretamente proporcional ao seu peso molecular (LAI et al., 1989). 
A primeira técnica empregada foi designada eletroforese em campo pulsado (PFGE - Pulsed Field Gel Eletrophoresis), a qual utiliza dois campos elétricos pulsados, um homogêneo e um não homogêneo. Utilizando esta técnica SCHWARTZ \& CANTOR (1984) separaram bandas cromossômicas de $S$. cerevisiae com peso molecular superiores a $700 \mathrm{~Kb}$.

Algumas modificações foram efetuadas principalmente com relação a disposição dos eletrodos na cuba (CARLE \& OLSON, 1984). Esta alteração resultou na segunda técnica, OFAGE (Orthogonal Field Alternation Gel Electrophoresis) a qual utiliza dois campos elétricos não homogêneos. Como os campos elétricos não eram uniformes e o ângulo entre eles variava através do gel, uma melhor resolução foi observada quando comparada com o PFGE, pois o padrão de migração era mais linear, o que permitia também colocar mais amostras no gel. Utilizando este novo sistema foram feitos os "cariótipos eletroforéticos" de $S$. cerevisiae (CARLE \& OLSON, 1984), Candida spp. (MAGEE \& MAGEE, 1987), Ustilogo maydis (KINSCHERF \& LEONG, 1988), Kluyveromyces marxianus (BERGKAMP et al., 1991) e Ophiostoma ulmi (DEWAR \& BERNIER, 1993).

Um terceiro sistema surgiu quando GARDINER et al. (1986) modificaram o sistema anterior (OFAGE) orientando o campo elétrico transversalmente no gel (TAFE). $\mathrm{O}$ ângulo entre os campos elétricos variava da superfície superior a superfície inferior do gel. Através deste sistema foram produzidos os "cariótipos eletroforéticos" de $S$. cerevisiae (GARDINER \& PARTESSON, 1988), Schizosaccharomyces pombe (STEWART et al., 1988), Cephalosporium acremonium (SKATRUD \& QUEENER, 1989), Septona tritici (McDONALD \& MARTINEZ, 1991), Ophistoma ulmi (DEWAR \& BERNIER, 1993), Candida albicans (ALLEGRUCCI et al., 1993), dentre outros.

CARLE et al. (1986) desenvolveram um quarto sistema no qual os campos elétricos designado FIGE (Field Inversion Gel Electrophoresis) formam um ângulo de $180^{\circ}$ entre si, podendo separar grandes moléculas de DNA com a simples inversão periódica de um campo elétrico uniforme em uma direção. Para que a separação ocorra 
o tempo de pulso para avançar tem que ser superior ao tempo de pulso para reverter. A proporção utilizada normalmente é 3:1 segundos. Uma observação interessante é que dependendo das condições da corrida grandes fragmentos de DNA não migram necessáriamente em ordem de tamanho das moléculas (LALANDE et al., 1987). LOBRICH et al. (1993) demonstraram que o tempo de pulso e a resistência do campo elétrico podem interferir na migração das bandas no gel podendo haver uma inversão de bandas como verificado com os cromossomos IV e XII de $S$. cerevisiae. Tal fato já tinha sido observado por CARLE et al. (1986), sugerindo ser esta uma peculiaridade da estrutura do cromossomo XII, o qual tem centenas de genes de rRNA e rDNA repetidas em tandem.

LALANDE et al (1987) definiram um modelo matemático que determina os tempos de pulsos de acordo com o tamanho da molécula a ser separada, em substituição aqueles determinados empiricamente. $O$ sistema FIGE é largamente aplicado na separação de DNA de leveduras (CARLE et al., 1986; LOBRICH et al., 1993). Tal processo separa melhor moléculas de DNA inferiores a $750 \mathrm{~Kb}$. Segundo PIZZIRANIKLEINER \& AZEVEDO (1989) a utilização de uma cuba convencional é a vantagem dessa técnica em relação as demais.

Neste mesmo período outras modificações renderam o quinto sistema, o CHEF (Countour-Clamped Homogeneous Electric Fields), que foi descrito por CHU et al. (1986). O sistema CHEF é constituido de 24 eletrodos que oferecem ângulos de reorientação de $60^{\circ}$ ou $120^{\circ}$. Tal técnica fundamenta-se nos princípios da eletrostática para calcular as voltagens necessárias para gerar campos elétricos homogêneos, utilizando múltiplos eletrodos disposto ao longo de um contorno hexagonal, que unidos tem seus potenciais elétricos pré-determinados. Uma vantagem dessa técnica é que o padrão de separação das bandas independe da posição do gel, de modo que as bandas de DNA ficam em ordem linear; a outra vantagem $\hat{e}$ que a distribuição hexagonal permite separação de moléculas de DNA de até $2.000 \mathrm{~Kb}$ (PIZZIRANI-KLEINER \& AZEVEDO, 1989). Este sistema tem sido usado com sucesso para separar moléculas de 
DNA de alto peso molecular (superior a 5 megabases) quando alguns parâmetros são modificados, tais como, maior tempo de corrida, maior tempo de pulso e menor voltagem (VOLLHATH \& DAVIS, 1987).

Utilizando o sistema CHEF foram desenvolvidos os "cariótipos eletrofréticos" de $S$. cerevisiae (CHU et al., 1986; VOLLRATH \& DAVIS, 1987; MAGEE et al., 1988), S. pombe (VOLLRATH \& DAVIS, 1987; STEELE et al., 1989), Histoplasma capsulatum (STEELE et al., 1989), Neurospora crassa (ORBACH et al., 1988), Aspergilus nidulans (BRODY \& CARBON, 1989; MONTENEGRO et al., 1992), Phytophtora megasperma (HOWLETT, 1989), Colletotrichum gloesporoides (MASEL et al., 1990), Metarhizium anisopliase (KAVA-CORDEIRO, 1993), entre outros.

CHU \& GUNDERSON (1991) demonstraram que o sistema CHEF com algumas modificações viabiliza a separação de grandes moléculas em menor tempo. Resultados significativos foram também obtidos com os sistemas "rotating gel electrophoresis" (SEWER, 1987), "crossed field" (SOUTHERN et al., 1987), PHOGE (BANCROFT \& WOLK, 1988).

Um sistema controlado por computador denominado PACE (Programable Autonomously Controlled Electrodes) foi desenvolvido por CLARK et al (1988). Este permite a reorientação dos ângulos arbitrariamente utilizando para esse fim 24 amplificadores operacionais de alta voltagem, tornando o sistema um tanto quanto dispendioso.

A Tabela 1 mostra alguns exemplos de leveduras com seus "cariótipos eletroforéticos" já publicados. 
Tabela 1. Cariótipos eletroforéticos de leveduras deterninados por eletroforese en canpo pulsado.

\begin{tabular}{|c|c|c|c|}
\hline $\begin{array}{l}\text { Cênero e } \\
\text { Espécie }\end{array}$ & $\begin{array}{l}\mathbb{H}^{2} \text { Haploide de } \\
\text { Cromossomos }\end{array}$ & $\begin{array}{l}\text { Variação de } \\
\text { Tamanho ( }(\mathbb{b})\end{array}$ & Referência \\
\hline Candida albicans & 7 & $1,1-2,2$ & MAGER \& HAGEE, 1987 \\
\hline c. stellatoidea & 9 & - & MAGEE \& HAGEE, 1987 \\
\hline c. glabrata & 10 & - & MAGEE \& MAGEE, 1987 \\
\hline c. quillermondi & 6 & & MAGEE \& MAGEB, 1987 \\
\hline Hansenula spp. & 4 & $0,7=1$ & DE JONGB et al., 1986 \\
\hline Kluyveromyces marxianus & $5-7$ & $1,0=4,0$ & STEENSHA et al., 1988 \\
\hline Phytophthora megasperma & $9-14$ & $1,0-4,0$ & HOWLETT, 1989 \\
\hline Phytophthora Sp. & $?-40$ & - & TOOLEY \& CARRAS, 1992 \\
\hline Rhodosporiun turoloids & 10 & $0,4-4,0$ & DE JOHGE et al., 1986 \\
\hline Rhodotorula mucilaginosa & 9 & $0,2-1,0$ & DE JOHGE et al., 1986 \\
\hline Saccharomyces cerevisiae & 16 & $0,2-2,2$ & CHo et al., 1986 \\
\hline S. uvarun & $14-15$ & $0,2-2,0$ & JAGER \& PHILIPPSEH, 1989 \\
\hline Schizosaccharonyces pombe & 3 & $3,5-5,7$ & SHITH et al., 1987 \\
\hline
\end{tabular}

As metodologias para a preparação das amostras são distintas e peculiares para cada organismo. No entanto, um fator essencial em todos os procedimentos é a manutenção das moléculas de DNA. Para garantir isso, CARLE \& OLSON (1986) sugerem que as células ou esferoplastos devem ser lisados em uma matriz semi-sólida. TALBOT et al. (1991) sugerem também o uso de luvas durante o manuseio e um tratamento especial à vidraria e outros materiais utilizados para garantir a ausência de nucleases, evitando assim a degradação do DNA (SMITH et al., 1987).

Geralmente, para preparar amostras de leveduras primeiro são obtidos os protoplastos que são posteriormente embebidos em agarose, seguindo-se o tratamento com detergentes e enzimas proteolíticas em temperaturas elevadas. Trabalhos recentes vêm simplificando o método de preparação das amostras, onde não é necessário à obtenção de protoplastos (McCLUSKEY et al., 1990) e o tratamento com enzimas proteolíticas em temperaturas elevadas (MIAO \& VANETTEN, 1990) para a definição de bandas cromossômicas num gel de eletroforese. 
Segundo CANTOR et al. (1988) alguns parâmetros bem estabelecidos podem render melhor resolução do perfil eletroforético. São eles:

- concentração de DNA nas amostras;

- concentração da agarose, e tipo;

- propriedades das moléculas de DNA;

- tempo de corrida;

- tempo de pulso;

- voltagem;

- ângulo do pulso;

- temperatura e

- forma do campo elétrico.

Muitas variáveis podem afetar a separação dos fragmentos em eletroforese em campo pulsado. Migrações rápidas ocorrem em géis de baixa concentração de agarose. A variável mais crítica segundo LAI et al. (1989) é o tempo de pulso, o qual deve ser selecionado para que as moléculas de DNA gastem a maior parte da duração do pulso reorientando-se e não movendo-se através do gel (MILLS \& McCLUSKEY, 1990). O tempo de corrida deve ser aumentado quando se trabalha com moléculas de alto peso molecular. Quanto à voltagem um gradiente de $6-10 \mathrm{~V} / \mathrm{cm}$ pode ser usado para separar moléculas de até um megabase. A resolução de moléculas maiores requer a redução do gradiente. $O$ ângulo de reorientação é muito importante. Muitos aparelhos utilizam ângulos fixos de $120^{\circ}$ entre os campos pulsados. A temperatura também influencia na mobilidade do DNA, pois com o aumento da temperatura, as moléculas reorientam-se mais rapidamente. As temperaturas entre $14^{\circ} \mathrm{Ce} 22^{\circ} \mathrm{C}$ produzem melhores resultados. Flutuações na temperatura durante o experimento podem interferir na resolução das bandas.

$O$ avanço da eficiente técnica de eletroforese em campo pulsado, primeiramente desenvolvida em S. cerevisiae (SCHWARTZ \& CANTOR, 1984), tem 
surgido como um recurso adicional para o estudo de genética básica em muitos organismos (ALLEGRUCCI et al., 1993).

Os vários sistemas de eletroforese em campo pulsado, previamente citados para o estudo de DNA cromossômico intacto de microrganismos, tem sido importantes para elucidação da organização, sistemática e evolução do genoma de eucariotos (NAUMOV et al., 1992).

\subsubsection{Aplicações gerais}

A eletroforese em campo pulsado tem se consagrado como uma técnica eficiente na separação de DNA cromossômico de muitos microrganismos. A aplicação desta técnica tem sido de amplo espectro para a localização física de genes, construção de bancos genômicos de cromossomos específicos, identificação de aberrações cromossômicas (aneuploidia, deleções, inversões, duplicações e translocações), etc.

Para muitos fungos existem poucos ou não há dados genéticos. Mas utilizando um cariótipo molecular combinado com técnicas de hibridização com sondas marcadas genes clonados podem ter sua localização cromossômica determinada sem a necessidade de cruzamentos e testes de progênie (STRINGER et al., 1991). Esta técnica permite a localização dos genes, podendo determinar se a herança poligênica está presente no mesmo grupo de ligação ou não e determinar este grupo (ABRAHAM et al., 1992).

Através da técnica de separação de DNA cromossômico usando o CHEF, BERGKAMP et al. (1993) utilizaram uma sonda isolada de $S$. cerevisiae codificando o gene ura3, mapeado no cromossomo $\mathrm{V}$ e uma cópia simples deste gene foi localizada no cromossomo VI da levedura $K$. marxianus. Num trabalho anterior utilizando o sistema CHEF foi observado 8 grupos de ligação para o gênero Kluyveromyces, porém, quando o sistema OFAGE foi usado, detectou-se um grupo de ligação a menos, podendo estar havendo uma co-migração de bandas (BERGKAMP et al., 1991). 
TEUNISSEN et al., (1993) utilizando a técnica do CHEF e hibridização fizeram a localização física do gene de floculação flol no cromossomo I de $S$. cerevisiae. Utilizando a mesma técnica SUMRADA \& COOPER (1992) localizaram o gene car que codifica a proteína arginase no braço direito do cromossomo XVI de $S$. cerevisiae.

$\mathrm{O}$ gene rodA havia sido clonado, mas não se tinha idéia da sua localização. Foi feito o cariótipo eletroforético de uma linhagem de Aspergillus nidulans e a hibridização destes com o gene rodA. Foi observado que este gene hibridizava com o cromossomo III de $A$. nidulans (STRINGER et al., 1991).

MONTENEGRO et al. (1992) usando o CHEF e técnicas de hibridização com sonda marcada, contendo os genes da via biossintética da penicilina, promoveram o mapeamento destes genes no cromossomo VI e do gene $\arg B$ no cromossomo III de A. nidulans.

Empregando a técnica de eletroforese em campo pulsado é possível a construção de um banco genômico de um único cromossomo. Após a separação dos cromossomos em gel de agarose, um cromossomo específico pode ser cortado do gel, clivado com uma enzima de restrição específica, produzindo fragmentos de 2-10 Kb. Estes fragmentos podem ser retirados do gel por eletroeluição, constituindo-se em uma fonte de DNA para clonagem em um vetor plasmidial ou para outros estudos. Esta técnica também se aplica para classificar bibliotecas genômicas por cromossomo. BRODY et al. (1991) organizaram por cromossomo, os clones de bibliotecas genômicas de $A$. nidulans.

A eletroforese em campo pulsado tem permitido recentes descobertas da presença de cromossomos supernumerários ou cromossomos B em fungos. Tal cromossomo não é vital para o organismo e é muito frequente em animais e plantas. Já foram encontrados em S. pombe (NIWA et al., 1986), Magnoporte grisea (ORBACH, 1989), Colletotrichum gloeosporioides (MASEL et al., 1990) e Nectria haematococca (MIAO, 1990). 
Grande grau de polimorfismo tem sido notado entre mini-cromossomos (menores que 2Mb) entre diferentes isolados do mesmo fungo (SKINNER et al., 1990; MASEL et al., 1990; ORBACH, 1989). Os genes responsáveis pela patogenicidade de Nectria haematococca foram localizados em um cromossomo de 1,6 $\mathrm{Mb}$. Os isolados que não são patogênicos também não apresentam este mini-cromossomo. Tal fato permite concluir que este cromossomo não é essencial para a sobrevivência do organismo, mas é responsável pela sua patogenicidade (MIAO, 1990).

BIDENNE et al. (1992), usando o sistema TAFE e a técnica de hibridização com sondas específicas, observaram a presença de cromossomos hibridos em linhagens de $S$. cerevisiae de vinho. Foi verificado co-hibridização da sonda do braço esquerdo do cromossomo I com a sonda do braço direito do cromossomo III. Estes constituem-se num excelente material para estudos intracromossômicos (deleções/duplicações) ou intercromossômicos (translocações).

Polimorfismo entre linhagens, provocados por translocações, foi primeiramente observado em linhagens de $S$. cerevisiae (SCHWARTZ \& CANTOR, 1984). As mesmas observações foram feitas por MAGEE \& MAGEE (1987), estudando 5 isolados de Candida albicans.

ORBACH et al. (1988) obteve o perfil eletroforético de Neurospora crassa. Sete bandas definidas foram obtidas e seus tamanhos estimados. Foi também observado DNAs mini-cromossomais gerados a partir de linhagens com translocações.

BRODY et al. (1989) têm descrito translocação em $A$. nidulans utilizando os mesmos métodos.

Rearranjos cromossômicos também foram observados por ADAMS et al. (1992) em linhagens haplóides e diplóides de $S$. cerevisiae, principalmente eventos de translocações, duplicações e deleções. Tais rearranjos indicam ocorrência de adaptação genética ao meio. Esse é um caminho que permite estudos sobre modificações estruturais no genoma das leveduras, as quais garantem sua adaptação a novos ambientes contribuindo para sua evolução e garantindo a sua sobrevivência. 
Foi observado em linhagens de Zygosacharomyces co-migração de bandas aneuplóides e poliplóides (TOROK et al., 1992). Também foi demonstrado polimorfismo no comprimento dos cromossomos de leveduras industriais, sugerindo rearranjos cromossomais tais como inserção, deleçōes, duplicações e translocações. O autor sugere que estas técnicas moleculares podem ser usadas nos estudo de diversidade genética e também para a identificação de leveduras. A maior vantagem deste método de hibridização DNA-DNA é que não é requerido o conhecimento da sequência da sonda usada para a reação espécie específica, basta saber a qual grupo de ligação pertence.

Utilizando a técnica de eletroforese em campo pulsado QUEIROZ (1993) identificou um segmento duplicado em linhagens de $A$. nidulans, estimou o tamanho da duplicação e estabeleceu a associação desta duplicação à instabilidade genética destas linhagens.

Em seu trabalho, NAUMOV et al. (1992) puderam demonstrar que as três espécies do gênero Saccharomyces: $S$. cerevisiae, $S$. paradoxus e $S$. bayanus apresentam 16 cromossomos. Reveleram também o baixo grau de homologia entre os genes estudados de $S$. cerevisiae com as demais espécies.

Através destas técnicas moleculares a distância física entre duas marcas geneticamente ligadas têm sido determinada. Outra possibilidade é de determinar o tamanho de genes repetidos em "tandem". Isto é possível promovendo a digestão do DNA com enzimas que cortam em sítios raros, seguido da separação dos fragmentos em gel de eletroforese e posterior hibridização com marcas que estão geneticamente ligadas. Melhores resultados são obtidos quando várias enzimas de restrição são usadas e também digestões parciais (SKINNER et al., 1991).

Também em leveduras, estudos de taxonomia estão sendo realizados (DE JONGE et al., 1986). Comparando-se 26 espécies de leveduras de 16 gêneros diferentes foram observadas variaçōes no número de bandas e nas suas posiçōes no gel entre gêneros diferentes, entre espécie do mesmo gênero e entre variedades da mesma espécie. 
A técnica de eletroforese em campo pulsado possibilita o conhecimento do padrão de bandas de um produto de fusão interespecífico e permite identificar cromossomos paternos que foram mantidos no híbrido. Ela surge também como um recurso importante na caracterização de leveduras, possibilitando um rápido avanço no conhecimento da diversidade genética a nível cromossômico e contribuindo ainda como mais um parâmetro no controle de qualidade e taxonomia de leveduras e de outros fungos (MILLS \& McCLUSKEY, 1990; NAUMOV et al, 1992). 


\section{MATERIAIS E MÉTODOS}

\subsection{Microrganismos utilizados}

As linhagens de Saccharomyces cerevisiae sensíveis ao metolachlor são provenientes do acervo mantido no laboratório de Genética de Leveduras da Escola Superior de Agricultura "Luiz de Queiroz" - USP.

A linhagem resistente é resultado de estudos anteriores desenvolvidos no Laboratório de Genética de Leveduras da ESALQ/USP. Esta foi selecionada em meio contendo YEPD (ítem 3.3.1.) acrescido de $360 \mathrm{mg} / \mathrm{l}$ metolachlor, após ser irradiada com luz ultra violeta durante 60 segundos (ECHEVERRIGARAY et al., 1991).

Tabela 2. Linhagens de Saccharomyces cerevisiae utilizadas nos processos de transformações e sua procedência.

\begin{tabular}{lll}
\hline Linhagem & Procedência & Resistência \\
\hline S. cerevisiae MD 3000 & ESALQ/USP & MTC $^{\mathrm{R}}$ \\
S. cerevisiae GRF-18 & ESALQ/USP & MTC $^{\mathrm{s}}$ \\
S. cerevisiae M 304-2C & ESALQ/USP & MTC $^{\mathrm{s}}$ \\
S. cerevisiae M 300 A & ESALQ/USP & MTC $^{\text {s }}$ \\
S. cerevisiae AH22 & ESALQ/USP & MTC $^{\text {s }}$ \\
\hline
\end{tabular}

Foram também utilizadas linhagens de Escherichia coli DH alfa 5 nos experimentos de transformação bacteriana 


\subsection{Plamídio utilizado}

YEp 351 - É um plasmídio bifuncional com 5.644 Kb que foi utilizado como vetor de clonagem para $S$. cerevisiae e $E$. coli. Este plasmídio tem a capacidade de se replicar em ambos os organismos devido a presença de uma sequência do plasmídio endógeno de $S$. cerevisiae, o $2 \mu \mathrm{m}$, e por possuir parte do plasmídio bacteriano pBR322. Como marcadores seletivos tem-se leu2 para $S$. cerevisiae e amp e lacZ para $E$. coli. O plasmídio foi utilizado nos processos de clonagem do gene do metolachlor.

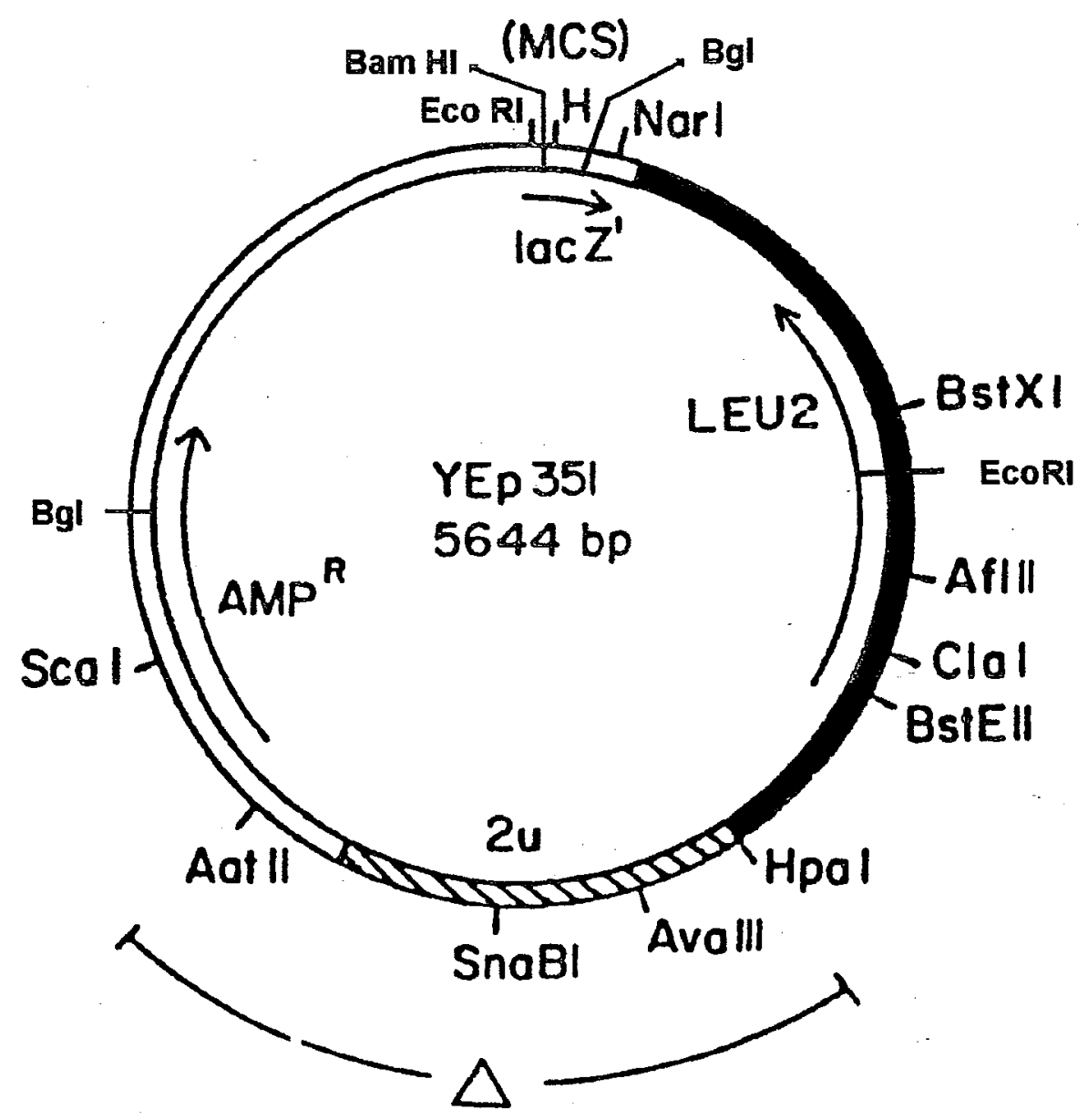

Figura 2. Plasmídio YEp 351. 


\subsection{Meios de cultura}

\subsubsection{Meio completo (YEPD)}

Extrato de levedura ................................... 1,0\%

Peptona ............................................. 2,0\%

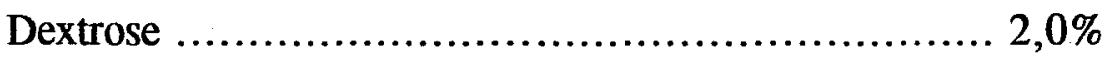

Ágar (opcional) .................................. 2,0\%

Dissolver em água destilada

Meio utilizado para a manutenção de cultura, multiplicação das células, preparo de inóculo nos ensaios, crescimento e seleção dos transformantes, assim como na análise do grau de resistência, estabilidade, etc.

$\mathrm{O} \mathrm{pH}$ não precisou ser ajustado, ficando em torno de 6,8 .

3.3.2. Meio de Luria e Bertani (MANIATIS etl., 1982)

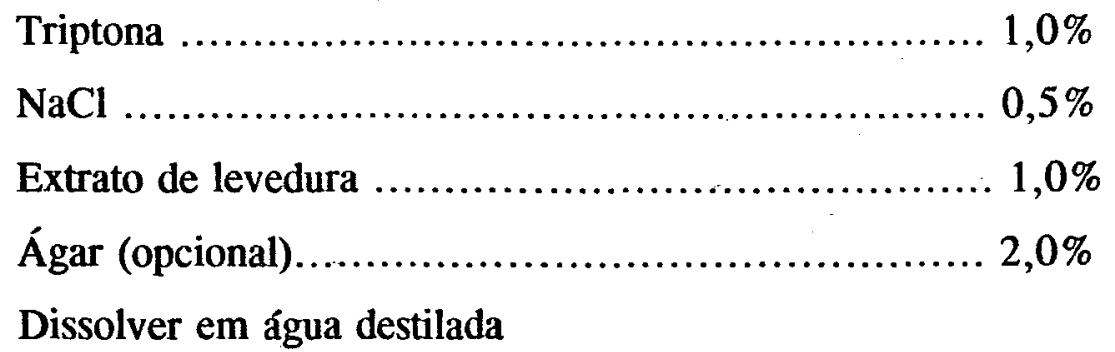

$\mathrm{O}$ pH foi ajustado para 6,8, com $\mathrm{NaOH} 1 \mathrm{~N}$. Este meio foi empregado para o crescimento e seleção dos transformantes em $E$. coli e para crescimento das linhagens bacterianas, das quais foram extraídos os plasmídios. 


\subsubsection{Meio mínimo (YNB)}

Yeast Nitrogen base

$0,67 \%$

Dextrose $2 \%$

Ágar (Difco) opcional $2 \%$

Dissolvido em água destilada e acertado o $\mathrm{pH}$ para 6,8. Meio utilizado na seleção de tranformantes de leveduras.

Todos os meios foram esterilizados por autoclavagem à 1 atmosfera durante 20 minutos.

\subsection{Herbicida utilizado}

Utilizou-se o Dual $720 \mathrm{EC}$, tendo como princípio ativo o metolachlor na concentração do fabricante (Ciba Geigy) de $720 \mathrm{~g} / 1$.

\subsection{Soluções e tampões}

3.5.1. Solução estoque de ampicilina (500 x)

Ampicilina $250 \mathrm{mg}$

Água destilada $10 \mathrm{ml}$

A solução foi esterilizada por filtragem, mantida a $20^{\circ} \mathrm{C}$ e utilizada na concentração final de $50 \mu \mathrm{g} / \mathrm{ml}$. 


\subsubsection{Solução de lisozima}

EDTA (ácido etileno diamino tetracético) $10 \mathrm{mM}$

Glucose $50 \mathrm{mM}$

Tris $\mathrm{HCl}$ $25 \mathrm{mM}$

$\mathrm{O} \mathrm{pH}$ foi ajustado para 8,0 pela adição de $\mathrm{HCl}$ a $37 \%$ e a esterilização foi feita por filtragem. A lisozima foi adicionada no momento da utilização numa concentração de $2 \mathrm{mg} / \mathrm{ml}$.

A solução foi utilizada para lise das células bacterianas durante a extração do DNA plasmidial.

\subsubsection{Solução de SDS alcalino}

$\mathrm{NaOH}$ $0,2 \mathrm{~N}$

SDS $1,0 \%$

Água destilada $9,0 \mathrm{ml}$

A solução foi utilizada para a extração de DNA plasmidial e preparada no momento do uso.

3.5.4. Solução de acetato de sódio

$\mathrm{NaAc}$

$\mathrm{O} \mathrm{pH}$ foi ajustado para 4,8 com ácido acético glacial. A solução foi utilizada na extração de DNA plasmidial. 


\subsubsection{Solução de X-Gal (5-Bromo-4-Chloro-3-indolyl-B-Dgalactosidase)}

Uma solução de $20 \mathrm{mg} / \mathrm{ml}$ foi preparada dissolvendo a X-gal em dimethylformamida. Esta solução foi estocada a $-20^{\circ} \mathrm{C}$. Adicionou-se $40 \mu 1$ desta solução em placas contendo LB e ampicilina.

\subsubsection{Solução de IPTG (Isopropylthio-B-D-galactoside)}

Preparou-se uma solução estoque de $120 \mathrm{mg}$ de IPTG em $5 \mathrm{ml}$ de água destilada filtrada em sistema Milipore. Foi utilizado $20 \mu \mathrm{l}$ em cada placa.

\subsubsection{Solução estoque de RNAse}

Uma solução estoque de $10 \mathrm{mg} / \mathrm{ml}$ foi preparada adicionando-se RNAse, em uma solução de Tris- $\mathrm{HCl} 10 \mathrm{mM}, \mathrm{pH} 7,5,15 \mathrm{mM} \mathrm{NaCl}$. Esterilizou-se a $100^{\circ} \mathrm{C}$ durante 15 minutos.

\subsubsection{Solução de SDS $10 \%$}

Dissolveu-se em água destilada. Utilizada para o isolamento de DNA de leveduras.

3.5.9. Solução estoque de SSC (20x)

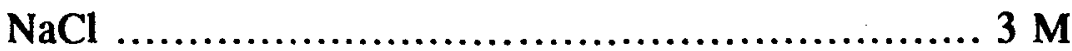

Citrato trisódico ................................... 0,3 M 
Ajustado o pH para 7,0. Utilizada para isolamento de DNA e nos processos de hibridização.

3.5.10. Solução de brometo de etídio (MANIATIS et al., 1982)

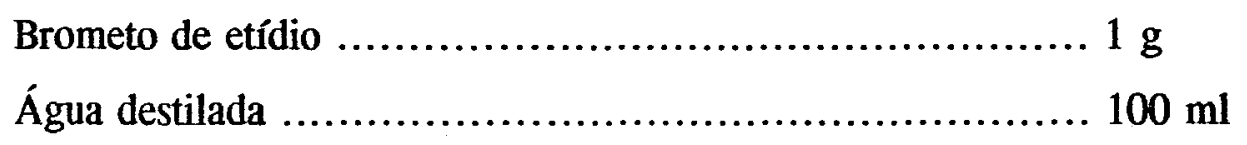

Para melhor dissolução, várias horas de agitação foram necessárias e a solução foi estocada à temperatura de $4^{\circ} \mathrm{C}$, sendo posteriormente utilizada nos tampões de eletroforese de DNA como agente intercalante. O DNA pode ser evidenciado sob transiluminador U.V.

3.5.11. Solução de polietilenoglicol (PEG)

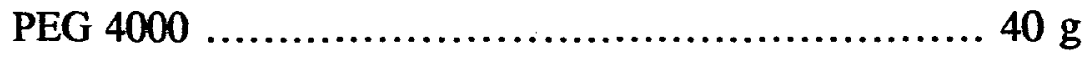

Água destilada ................................... $100 \mathrm{ml}$

A solução foi autoclavada a $120^{\circ} \mathrm{C}$ por 20 minutos.

\subsubsection{Fenol saturado}

Adicionou-se para cada $100 \mathrm{ml}$ aproximadamente $500 \mathrm{mg}$ de hidroxiquinolina. E adicionou-se TE, para que houvesse saturação, sob agitação até obter-se duas fases.

Utilizado para a precipitação de proteínas nas extrações de DNA. 


\subsubsection{Solução de EDTA $0,5 \mathrm{M}$}

EDTA $186,1 \mathrm{~g}$

Água destilada $1000 \mathrm{ml}$

Ajustou-se o pH para 8,0 com pastilhas $\mathrm{NaOH}$. Esterilizou-se em autoclave.

\subsubsection{Solução de NDS}

Tris-HCl pH 7,5 $0,01 \mathrm{M}$

EDTA pH 8,0 $0,45 \mathrm{M}$

$\mathrm{N}$-Laurilsarcosinato $1 \mathrm{~g}$

Proteinase $\mathrm{K}$ $1 \mathrm{mg} / \mathrm{ml}$

Acrescentou-se a proteinase no momento do uso.

\subsubsection{Solução de Novozym}

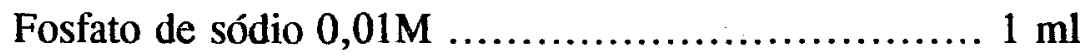

Glicerol .......................................... 1 ml

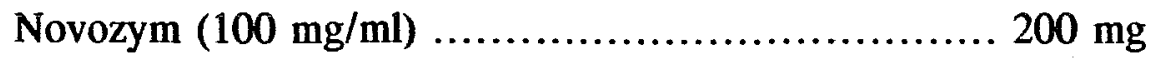

\subsubsection{Tampão TBE (5x)}

Tris base $54 \mathrm{~g}$

Ácido bórico $27,5 \mathrm{~g}$

EDTA $(0,5 \mathrm{M}, \mathrm{pH} 8,0)$ $20 \mathrm{ml}$ 
Completou-se o volume com água destilada. Esterilizou-se em autoclave. Foi utilizado TBE $(1 \mathrm{x})$ nos géis de agarose comum e TBE $(0,5 \mathrm{x})$ para separação de DNA cromossômico.

3.5.17. Tampão TE (MANIATIS et al., 1982)

Tris- $\mathrm{HCl}(\mathrm{pH} 8,0)$ $10 \mathrm{mM}$ EDTA $1 \mathrm{mM}$

Utilizado na ressuspensão de células e de DNA. Esterilizado em autoclave.

3.5.18. Tampão de tranformação (E. coli)

Tris- $\mathrm{HCl}(\mathrm{pH} \mathrm{8,0)}$ $5 \mathrm{mM}$

$\mathrm{CaCl}_{2}$ (dehidratado) $75 \mathrm{mM}$

Estocado em refrigerador após autoclavagem.

3.5.19. Tampão da amostra (TA) $6 \mathrm{x}$
Azul de Bromofenol
$0,25 \%$
Cianol xileno $\mathrm{FF}$ $0,25 \%$
Ficol (tipo 400) $15 \%$

Diluiu-se para 1x no momento do uso. Estocou-se a temperatura ambiente.

\subsubsection{Tampão LET}

EDTA (pH 8,0) $0,45 \mathrm{M}$

Tris- $\mathrm{HCl}(\mathrm{pH} \mathrm{7,5)}$ $0,01 \mathrm{M}$

2-Mercaptoetanol $7,5 \%$ 
3.5.21. Solução desnaturante

$\mathrm{NaOH}$ $1 \mathrm{M}$

$\mathrm{NaCl}$ $2,5 \mathrm{M}$

\subsubsection{Solução neutralizante}

Tris-HCl pH 7,6 ................................. 0,5 M

$\mathrm{NaCl}$ $3 \mathrm{M}$

3.5.23. Solução de lavagem primária (hibridização)

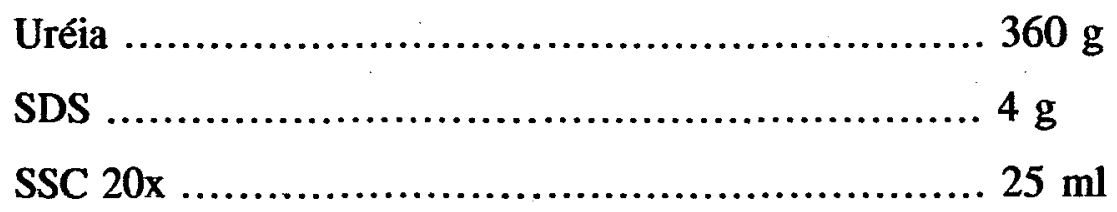

Completou-se o volume para $1000 \mathrm{ml}$

3.5.24. Solução de lavagem secundária (hibridização)

SSC 20x $100 \mathrm{ml}$

Completou-se o volume para $1000 \mathrm{ml}$

3.6. Isolamento de DNA de leveduras com nitrogênio líquido

As linhagens foram crescidas em $50 \mathrm{ml}$ de YEPD (ítem 3.3.1.) por 15 horas a $30^{\circ} \mathrm{C}$ com agitação $(200 \mathrm{rpm}$ ) e centrifugadas a $4.000 \mathrm{rpm}$ por 15 minutos. $\mathrm{O}$ sobrenadante foi descartado e a massa fresca foi transferida para um almofaris. Adicionou-se ao almofaris nitrogênio líquido e com a ajuda de um pistilo as células 
foram maceradas (repetiu-se este passo 3 vezes). $O$ material foi ressuspendido em $2 \mathrm{ml}$ de Tris-HCl 0,1M pH 8,0 com 10\% 2-mercaptoetanol. Posteriormente foi dividido em 4 tubos Eppendorf, aproximadamente $600 \mu \mathrm{l} \mathrm{em}$ cada e adicionou-se $50 \mu \mathrm{l}$ de SDS $10 \%$. A lise foi observada pelo aspecto gelatinoso da suspensão. Acrescentou-se $600 \mu 1$ de clorofórmio-isoamílico (24:1) e agitou-se os tubos lentamente até a formação de uma suspensão esbranquiçada homogênea. $O$ material foi centrifugado a $12.000 \mathrm{rpm}$ por 10 minutos. Coletou-se o líquido da parte superior, transferindo-o para outros tubos de Eppendorf (repetiu a desproteinização por 2 vezes). Após a desproteinização, o conteúdo dos 4 tubos de Eppendorf foi somado em um tubo de $15 \mathrm{ml}$ e adicionou-se etanol gelado (o dobro do volume contido no tubo). Após agitar lentamente o tubo a precipitação do DNA foi observada (deixando na geladeira por 30 minutos). Descartou-se o etanol e o tubo ficou aberto para a sua total evaporação. $O$ precipitado foi ressuspendido em SSC ou TE (1x), seguindo-se então o tratamento com RNAse $(1 \mathrm{mg} / \mathrm{ml})$ à $30^{\circ} \mathrm{C}$ por 60 minutos. Repetiu os passos da desproteinização e precipitação com etanol. Procedeu-se com a ressuspensão em TE ou SSC (1x).

\subsection{Extração de DNA plasmidial}

A aplicação desta metodologia abrange extrações de pequenas e grandes quantidades de DNA alterando-se apenas o volume das soluções. Para a extração em grande escala inicia-se o procedimento com a obtenção de um pré-inóculo.

\subsubsection{Minipreparação}

Foram inoculadas células de uma colônia de DH alfa 5, carregando o plasmídio de interesse, em meio LB contendo $50 \mu \mathrm{g} / \mathrm{ml}$ de ampicilina. Incubou-se a $37^{\circ} \mathrm{C}$ por 18 horas, sob agitação $(200 \mathrm{rpm})$. As células foram centrifugadas em microcentrífuga a $12.000 \mathrm{rpm}$ por 1 minuto e o sobrenadante descartado. Após a 
precipitação as células foram ressuspendidas em $100 \mu \mathrm{l}$ da solução de lisozima (ítem 3.5.2.) com auxílio de vortex e mantidas no gelo por 30 minutos. Em seguida, adicionou-se $200 \mu \mathrm{l}$ de SDS-alacalino (ítem 3.5.3.), homogeneizou-se lentamente até surgir uma solução transparente e incubou-se no gelo por 5 minutos. Então foram adicionados $150 \mu \mathrm{l}$ de NaAc 3M (ítem 3.5.4.) e após homogeneizar lentamente incubouse no gelo por 30 minutos. Depois de 15 minutos de centrifugação o sobrenadante foi transferido para Eppendorfs limpos. Adicionou-se 2 vezes o volume de etanol absoluto gelado e incubou-se por 1 hora a $-20^{\circ} \mathrm{C}$. Centrifugou-se por 15 minutos, desprezou-se o sobrenadante e deixou-se o Eppendorf invertido para secar em uma estufa a $37^{\circ} \mathrm{C}$ durante 1 hora. $O$ precipitado foi ressuspendido em $100 \mu 1$ de TE.

O DNA extraído quando necessário foi tratado com RNAse ( $1 \mathrm{mg} / \mathrm{ml}$ ) e teve suas impurezas removidas através da extração com fenol/clorofórmio/isoamílico antes da precipitação com etanol.

\subsubsection{Determinação da concentração de DNA plasmidial}

A determinação foi realizada fazendo-se a leitura das amostras contendo o DNA plasmidial contra um branco de TE $1 \mathrm{x}$ em espectrofotômetro a $260 \mathrm{~nm}$ de comprimento de onda.

O cálculo para determinar a concentração segue a fórmula abaixo:

[DNA] $\mu \mathrm{g} / \mathrm{ml}=\mathrm{OD}_{260} \times 50 \times$ diluição

onde:

[DNA] = concentração de DNA em $\mu \mathrm{g} / \mathrm{ml}$;

$\mathrm{OD}_{260}=\mu \mathrm{g}$ de DNA;

diluição = número de vezes da diluição da amostra antes da leitura. 


\subsection{Eletroforese em gel de agarose}

Durante várias etapas deste trabalho esta técnica foi aplicada. Na observação dos DNAs genômicos e plasmidial, monitoração dos processos de digestão e ligação de DNA e estimativa de número de peso molecular dos fragmentos do DNA plasmidial.

A eletroforese foi realizada em tampão TBE (1x) (ítem 2.5.15.). A concentração de agarose (tipo I-Sigma) foi de $0,8 \%$. O volume dos géis foram $80 \mathrm{ml}$ para os géis maiores e $40 \mathrm{ml}$ para as preparações de mini-géis.

A corrente elétrica para migração foi desde $15 \mathrm{~V}$, para os géis que foram corridos durante a noite até $70 \mathrm{~V}$. Maiores voltagens foram evitadas por causarem distorções nas corridas.

Foi adicionado aproximadamente $15 \mu 1$ de brometo de etídio $(100 \mathrm{mg} / \mathrm{ml})$ ao tampão TBE, durante 30 minutos para que os géis pudessem ser analisados e fotografados em transiluminador de U.V.

A revelação de tais filmes foram procedidas de acordo com as instruções do fabricante das soluções da revelação (Kodak).

Para o preparo do gel, a agarose foi misturada ao tampão TBE $1 \mathrm{x}$, sendo fundida por ebulição. Na aplicação do gel adicionou-se o tampão às amostras numa proporção mínima de $10 \%$ dos seus volumes e as amostras distribuídas nas canaletas do gel.

\subsection{Digestão dos DNAs genômicos e plasmidiais com endonucleases de restrição}

Para dar prosseguimento as etapas de ligação, clonagem e transformação, o DNA genômico da linhagem MD 3000 (resistente ao metolaclhor) e o plasmídio YEp 351 foram clivados com a endonuclease de restrição BamHI. Com a linhagem MD 
3000 , para um total de $100 \mu 1$, foram utilizadas $50 \mu 1$ de DNA genômico, $10 \mu 1$ de tampão digestão (10x), $1 \mu 1$ de BamHI e $39 \mu 1$ de água destilada esterilizada. A solução foi mantida a $37^{\circ} \mathrm{C}$ por 30-40 minutos. Após a digestão foi feita a extração com fenol e precipitação com etanol para evitar a transferência de nucleases nos processos posteriores.

Com o plasmídio o procedimento foi semelhante, somente para $20 \mu 1$ de YEp 351 adicionou-se $1 \mu \mathrm{l}$ de BamHI, $5 \mu 1$ de tampão (10x), $24 \mu 1$ de água destilada esterilizada. A solução foi incubada a $37^{\circ} \mathrm{C}$ por 3-4 horas. Em seguida procedeu-se a extração com fenol e precipitação com etanol.

\subsection{Ligação}

Para que ocorresse a ligação $20 \mu 1$ de DNA plasmidial e $40 \mu$ de DNA genômico foram incubados por 3-4 horas em temperatura ambiente numa solução contendo $1 \mu 1$ da enzima T4 DNA ligase, $10 \mu 1$ de tampão, $29 \mu 1$ da água destilada esterilizada.

\subsection{Transformação}

\subsubsection{Em Saccharomyces cerevisiae AH22}

\subsubsection{Método de IIMURA et al. (1983)}

As células de leveduras foram crescidas em meio YEPD (ítem 3.3.1.) durante 18 horas a $30^{\circ} \mathrm{C}$, sob agitação a $200 \mathrm{rpm}$ e posteriormente centrifugadas a 3000 rpm e lavadas com água destilada. Utilizando-se $5 \mathrm{ml}$ de $\mathrm{CaCl}_{2} 200 \mathrm{mM}(\mathrm{pH} 6,0)$, as mesmas foram ressuspendidas e incubadas a $0^{\circ} \mathrm{C}$ por 15 minutos, seguida de uma centrifugação a $3000 \mathrm{rpm}$ e ressuspensão em $600 \mu \mathrm{l}$ de uma solução $\mathrm{CaCl}_{2} 200 \mathrm{mM}$, 
$\mathrm{MgCl}_{2} 100 \mathrm{mM}$ e $400 \mu \mathrm{l}$ de Tris $10 \mathrm{mM}$. Foi adicionado $15 \mu \mathrm{l}$ da mistura de ligação em $200 \mu 1$ da solução. Incubou-se a $37^{\circ} \mathrm{C}$ por 5 minutos.

$O$ plaqueamento de $100 \mu \mathrm{l} /$ placa deu-se em YEPD acrescido de $720 \mathrm{mg} / 1$ de metolachlor e os transformantes foram selecionados após 2-3 dias de crescimento a $30^{\circ} \mathrm{C}$.

\subsubsection{Método de ITO et al. (1983)}

As células foram crescidas por 18 horas a $30^{\circ} \mathrm{C}$ sob agitação a $200 \mathrm{rpm}$, em $5 \mathrm{ml}$ de YEPD (ítem 3.3.1.), e uma alíquota de $500 \mu 1$, foi inoculada em $50 \mathrm{ml}$ de YEPD e crescida até o final da fase exponencial $\left(5 \times 10^{7}\right.$ células $\left./ \mathrm{ml}\right)$. As células foram centrifugadas a $3000 \mathrm{rpm}$ e lavadas em tampão TE (ítem 3.5.16.). Uma vez centrifugadas, ressuspendeu-se em $5 \mathrm{ml}$ de LiAc $250 \mathrm{mM}$ e deixou sob intensa agitação por 4 horas a $30^{\circ} \mathrm{C}$. Em seguida, alíquotas de $300 \mu \mathrm{l}$ foram distribuídas em tubos de Eppendorf e $10 \mu 1$ da mistura de ligação foram adicionadas, junto com PEG 4000 a $40 \%$. Após misturar-se cuidadosamente as células, incubou-se por 2 horas a $30^{\circ} \mathrm{C}$, aplicando-se a seguir um choque térmico de 5 minutos a $42^{\circ} \mathrm{C}$.

Aproximadamente $100 \mu 1$ de células foram plaqueadas em YEPD + metolachlor $(720 \mathrm{mg} / \mathrm{l})$ e selecionados após 2 ou 3 dias de crescimento a $30^{\circ} \mathrm{C}$.

Em ambos os métodos para tranformação de $S$. cerevisiae o controle negativo foi feito com células competentes e água.

\subsubsection{Em $E$. coli DH alfa 5}

A transformação de $E$. coli foi necessária para amplificar o número de cópias do plasmídio recombinante, sendo possível assim avaliar e caracterizar o mesmo. 


\section{Preparo de células competentes}

Células da linhagem de $E$. coli DH alfa 5 foram crescidas sob agitação (200 rpm) em $5 \mathrm{ml}$ de LB (ítem 3.3.2) durante 18 horas a $37^{\circ} \mathrm{C}$, servindo de préinóculo. Para o preparo do inóculo $500 \mu 1$ da cultura foram cultivados em $50 \mathrm{ml}$ de LB, sob agitação, durante 2,5 horas a $37^{\circ} \mathrm{C}$. Após centrifugação a $6000 \mathrm{rpm}$ durante 25 minutos a $4^{\circ} \mathrm{C}$, as células foram colocadas em gelo e ressuspendidas em $25 \mathrm{ml}$ do tampão de transformação gelado (ítem 3.5.17.). Durante 1 hora as células foram mantidas no gelo e então centrifugadas novamente. $O$ sobrenadante foi então descartado e o precipitado ressuspendido em $3 \mathrm{ml}$ de tampão de transformação gelado.

\section{Transformação das células competentes}

Alíquotas de $100 \mu l$ da suspensão de células competentes foram distribuídas em tubos Eppendorf e mantidas no gelo. Adicionou-se então 10 $\mu 1$ de DNA e incubou-se no gelo de 40-60 minutos, tomando-se o cuidado de agitar os tubos periodicamente. Procedeu-se um choque térmico de 2 minutos a $42^{\circ} \mathrm{C}$ e em seguida os tubos foram colocados no gelo. Adicionou-se $900 \mu 1$ de meio LB e incubou-se por 30-45 minutos a $37^{\circ} \mathrm{C}$. As células foram plaqueadas em LB contendo $50 \mu 1 / \mathrm{ml}$ de ampicilina para a seleção dos tranformantes.

Células competentes foram usadas como controle negativo e células transformadas com o plasmídio YEp 351 como controle positivo.

\subsection{Seleção direta dos transformantes}

Os transformantes resistentes ao metolachlor foram selecionados após 2-3 dias de incubação a $30^{\circ} \mathrm{C}$ em meio YEPD (ítem 3.3.1.) acrescido de $720 \mathrm{mg} / \mathrm{l}$ de metolachlor. 


\subsection{Digestão com enzimas de restrição}

Esta metodologia foi utilizada para construir o mapa de restrição do plasmídio recombinante.

Foram feitas hidrólises simples a fim de se identificar os diferentes sítios de restrição para caracterização do gene de resistência ao metolachlor.

Os plasmídios foram então digeridos com as seguintes enzimas: EcoRI, BamHI, HindIII, EcoRV, PstI, BglI, SmalI. A incubação foi feita de acordo com a recomendação do fabricante.

O marcador de peso molecular utilizado foi o fago lambda clivado com HindIII.

\subsection{Determinação do grau de resistência dos clones}

Os clones selecionados foram testados quanto a sua capacidade de crecimento em meio YEPD com concentrações variáveis de metolachlor.

Para tanto foram utilizadas como controle a linhagem sensível ao metolachlor e os clones selecionados.

As concentrações do metolachlor variaram de $72 \mathrm{mg} / 1$ a $720 \mathrm{mg} / 1$.

\subsection{Avaliação da estabilidade mitótica dos plasmídios}

A estabilidade mitótica do plasmídio pode variar. Para observar como o plasmídio comporta-se crescendo em meio sem pressão seletiva, as colônias dos clones transformados foram isoladas e crescidas em $5 \mathrm{ml}$ de meio seletivo (YEPD $+72 \mathrm{mg} / \mathrm{l}$ de metolachlor), até atingirem uma concentração de $5 \times 10^{3}$ células $/ \mathrm{ml}$ (contadas em câmara de Neubawer). 
Uma amostra de $200 \mu l$ foi inoculada em meio YEPD (ítem 3.3.1.) e em YEPD $+72 \mathrm{mg} / 1$ de metolachlor, incubando-se por 24 horas a $30^{\circ} \mathrm{C}$. Plaqueou-se 4 placas para o plasmídio pMTC15, uma vez que as amostras produziram aproximadamente 500 colônias por placas. Foram feitas réplicas e depois de 3 dias as colônias MTCr e MTCs foram contadas.

3.16. Separação de DNA cromossômico de leveduras através da eletroforese em campo pulsado, pelo sistema CHEF

\subsubsection{Preparação das amostras}

\subsubsection{Experimento 1 - Protocolo SCHWARTZ \& CANTOR} (1984)

A preparação de amostras envolveu o crescimento da linhagem até a fase estacionária, sob agitação à $30^{\circ} \mathrm{C}$. As amostras foram lavadas duas vezes e ressuspendidas em EDTA 0,05M pH 8,0 (ítem 3.5.15.).

Adicionou-se $100 \mu \mathrm{l}$ da solução de Novozym $234(10 \mathrm{mg} / \mathrm{ml})$ (ítem 3.5.15.) a cada $1 \mathrm{ml}$ da suspensão de células $\left(3 \times 10^{8}\right)$ e incubou-se a $37^{\circ} \mathrm{C}$ por 30 minutos. Para a confecção das amostras, agarose LGT $1,4 \%$ foi preparada em $0,125 \mathrm{M}$ de EDTA pH 7,5, fundida e deixada em banho maria a $42^{\circ} \mathrm{C}$ até o momento do uso. Adicionou-se em um Eppendorf $600 \mu 1$ de agarose LGT fundida e $600 \mathrm{ml}$ da suspensão de protoplastos, atingindo concentração final $0,7 \%$. Alíquotas de $200 \mu \mathrm{l}$ foram colocadas na cuba molde e incubados a $4^{\circ} \mathrm{C}$ por 20 minutos para que a agarose se solidificasse. As inclusões foram colocadas em tampão LET (ítem 3.5.20) e incubadas a $37^{\circ} \mathrm{C}$ overnight. O tampão LET foi removido e os blocos de agarose lavados 3 vezes durante 15 minutos em EDTA 0,05M pH 8,0. Os blocos de agarose foram ressuspendidos em tampão NDS (ítem 3.5.14) e incubou-se a $50^{\circ} \mathrm{C}$ overnight. Após a remoção do tampão NDS, as 
inclusões foram lavadas 3 vezes com EDTA $0,05 \mathrm{M}$ pH 8,0 durante 15 minutos à temperatura ambiente. Finalizando, as inclusões foram estocadas a $4^{\circ} \mathrm{C}$ em EDTA $0,05 \mathrm{M}$ pH 8,0.

As etapas de lavagem e estocagem foram idênticas nos demais métodos.

\subsection{1 .2. Experimento 2-Esferoplastização e desproteinização}

As células foram cultivadas em $50 \mathrm{ml}$ de meio YEPD (ítem 3.3.1.) durante 18 horas a $30^{\circ} \mathrm{C}$, sob agitação $(200 \mathrm{rpm})$. Após a centrifugação as células foram lavadas 3 vezes em EDTA $10 \mathrm{mM}$ pH 8,0 e ressuspendidas em $5 \mathrm{ml}$ do mesmo tampão. Adicionou-se $50 \mu 1$ de 2 Mercaptoetanol a $1 \%$ e incubou-se por 10 minutos a $30^{\circ} \mathrm{C}$. Lavou-se duas vezes, ressuspendeu-se as células em $2 \mathrm{ml}$ de EDTA $10 \mathrm{mM}$ e acrescentou-se $100 \mu 1$ da solução de Zymolyase $5000(2 \mathrm{mg} / \mathrm{ml})$. Incubou-se por 1 hora a $35^{\circ} \mathrm{C}$, agitando em intervalos de tempo. Após a centrifugação a $1000 \mathrm{rpm}$, lavou-se três vezes com EDTA $10 \mathrm{mM}$ e ressuspendeu-se no mesmo tampão. Uma alíquota de $600 \mu l$ da suspensão de protoplastos foi embebida em $600 \mu 1$ de LGT 1,4\% e mantida a $42^{\circ} \mathrm{C}$, originando as inclusões. Estas foram tratadas com enzimas proteolíticas a altas temperaturas (ítem 3.5.14). Seguem as estapas de lavagem e estocagem.

\subsubsection{Experimento 3 - Células intactas tratadas com detergentes e enzimas proteolíticas}

As linhagens foram crescidas em $50 \mathrm{ml}$ de meio YEPD (ítem 3.3.1.) durante 18 horas, sob agitação $(200 \mathrm{rpm})$ a $30^{\circ} \mathrm{C}$. As amostras foram lavadas duas vezes e ressuspendidas em $2 \mathrm{ml}$ de EDTA $0,05 \mathrm{M} \mathrm{pH} \mathrm{8,0} \mathrm{(ítem} \mathrm{3.3.13.).} \mathrm{As} \mathrm{células} \mathrm{intactas}$ foram embebidas em agarose formando as inclusões, as quais foram tratadas com detergentes (ítem 3.5.20) por 2 horas e com enzimas proteolíticas (ítem 3.5.14.) a $50^{\circ} \mathrm{C}$, overnight. Seguem os processos de lavagem, ressuspensão e estocagem. 
3.16.1.4. Experimento 4 - Células intactas desproteinizadas

As células foram cultivadas em $50 \mathrm{ml}$ de meio YEPD até a fase estacionária. As amostras foram lavadas duas vezes e ressuspendidas em EDTA 0,05 M pH 8,0. Após a preparação das inclusões contendo células intactas, estas foram mergulhadas em tampão NDS (ítem 3.5.14) e incubadas a $50^{\circ} \mathrm{C}$ overnight. Prosseguiu-se com as etapas de lavagem e estocagem.

\subsubsection{Experimento 5 - Células intactas tratadas com LiAc ou KAc e desproteinizadas}

As células foram cultivadas em 50ml de meio YEPD (ítem 3.3.1.) até a fase estacionária, com agitação a $30^{\circ} \mathrm{C}$. Estas foram lavadas duas vezes com EDTA $0,05 \mathrm{M}$ pH 8,0. Ressuspendeu-se em $3 \mathrm{ml}$ de acetato de lítio (LiAc) ou acetato de potássio (KAc) $250 \mathrm{mM}$ e incubou-se sob agitação por 4 horas a $30^{\circ} \mathrm{C}$. Após a obtenção dos blocos de agarose, estes foram inseridos em tampão NDS (ítem 3.5.14.) e mantidos durante a noite a $50^{\circ} \mathrm{C}$. Seguem as etapas posteriores de lavagem e estocagem.

\subsubsection{Preparação do gel para a corrida}

Pesou-se 1g de agarose específica (Sigma A 2929) e somou 100ml de TBE 0,5x (3.5.15.). Fundiu no microondas. Esperou-se esfriar durante 10 minutos e a agarose foi vertida na cuba molde. Após o resfriamento o gel ficou opaco. $O$ pente foi então removido e os blocos de agarose cuidadosamente colocados nas canaletas, devidamente identificados. Após a remoção de algumas bolhas as canaletas foram vedadas com agarose LGT para evitar a sarda dos blocos de agarose. 


\subsubsection{Preparação do aparelho (CHEF DR-II-BIO-RAD)}

O aparelho foi previamente lavado, recirculando com água deionizada onde foram colocados 2 litros do tampão TBE $(0,5 x)$. Após o gel ser mergulhado no tampão, prosseguiu-se com a programação do aparelho. Os parâmetros utilizados foram: voltagem $200 \mathrm{v}$, temperatura $14^{\circ} \mathrm{C}$, pulsos de 60 segundos por 15 horas e 90 segundos por 8 horas, totalizando 23 horas de corrida. Após o gel ser retirado da cuba este foi mergulhado numa solução de água destilada contendo $0,5 \mu \mathrm{g} / \mathrm{ml}$ de brometo de etídio para corar durante 30 minutos. Após o gel ser observado e fotografado em transiluminador U.V., uma fatia correspondendo as bandas dos cromossomos XV, VII e XVI, XIII foi cortada para posterior purificação.

\subsection{Eletroeluição em membrana diálise (MANIATIS et al., 1982)}

Com o auxilio de luvas os saquinhos de dialise foram cortados $(10 \mathrm{~cm})$ e lavados com água destilada. Após selar uma das extremidades da membrana com presilha, foi colocado o tampão TBE (1x) (ítem 3.5.16.) e os pedaços de agarose. A outra extremidade foi selada sem deixar bolhas de ar. O saquinho foi colocado na cuba de eletroforese contendo TBE (1x). A corrente elétrica utilizada foi de $5 \mathrm{~V} / \mathrm{cm}$ por 2 a 3 horas. Durante este período o DNA foi eletroeluído do gel. A polaridade da corrente foi revertida por 2 minutos para o DNA se desprender da parede da membrana. A membrana foi então retirada cuidadosamente do gel e assim todo o seu conteúdo tranferido para um tubo plástico. Com o auxilio de uma pipeta pasteur, o saquinho foi lavado com TBE (1x) acrescentado o volume ao tubo plástico. As fatias de agarose foram então coradas com brometo de etídio $(0,5 \mu \mathrm{g} / \mathrm{ml})$ e observadas em transiluminador para confirmar a eluição. O DNA eletroeluído foi purificado pela extração com solventes orgânicos. 
Este método foi utilizado para eletroeluir as bandas dos cromossômos $\mathrm{XV}$, VII e XVI, XIII de várias linhagens e também do fragmento do plasmídio pMTC15, que contém o gene MTCr utilizado como sonda nos processos de hibridização.

\subsection{Hibridização}

\subsubsection{Preparação da membrana com manchas de DNA pontuadas ("Dot blot")}

Uma micrograma de DNA foi desnaturada adicionando-se igual volume da solução desnaturante (ítem 3.5.19.) por 20 minutos a temperatura ambiente. $O$ volume requerido da amostra foi então colocado sobre a membrana de nylon, na posição marcada. Tomou-se cuidado para transferir tal volume de uma só vez. A membrana foi previamente tratada com uma solução de SSC 10x e seca por 1 hora, antes de receber as amostras. A membrana contendo as amostras foi colocada sobre uma camada dupla de papel de filtro umedecido em solução neutralizante (ítem 3.5.20) por 2 minutos. Esta foi então transferida para outro papel de filtro embebido com SSC $2 \mathrm{x}$ por 2 minutos. Após ter sido seca a temperatura ambiente o DNA foi fixado quando a membrana foi exposta a uma fonte de luz U.V. (254 nM) por 2 minutos.

\subsubsection{Pré-hibridização da membrana e preparação da sonda}

As membranas foram embebidas numa solução de hibridização do kit ECL e colocadas em banho maria a $42^{\circ} \mathrm{C}$ por 30 minutos. A quantidade de solução foi $0,25 \mathrm{ml}$ para cada $\mathrm{cm}^{2}$ de membrana.

Durante este período a sonda foi marcada com ECL (Enhanced Chemiluminescence), um sistema de deteç̧ão de gene usando um kit de Amersham, U.K. O procedimento foi desnaturar a sonda, que foi previamente linearizada e 
dessalinizada fervendo-a por 5 minutos e colocando-a no gelo por 5 minutos. A marcação seguiu colocando igual volume de peroxidase, agitando em vortex e colocando também igual volume de glutaraldeído. Incubou-se a $37^{\circ} \mathrm{C}$ por 10 minutos.

\subsubsection{Hibridização}

Após o período de pré-hibridização a sonda marcada foi adicionada à solução de hibridização evitando colocá-la diretamente sobre a membrana. Foram utilizados $20 \mathrm{ng}$ de DNA/ml de solução de hibridização. Prosseguiu-se a incubação com agitação à $60 \mathrm{rpm}$ a $42^{\circ} \mathrm{C}$ por 16 horas.

Terminada a hibridização, a sonda foi removida, a membrana foi coberta pela solução de lavagem primária (ítem 3.5.2.) e incubada com agitação por 10 minutos a $42^{\circ} \mathrm{C}$ por 2 períodos. Posteriormente, a membrana foi embebida na solução de lavagem secundária (ítem 3.5.23.) e incubada com agitação por 5 minutos à temperatura ambiente por mais 2 períodos.

Após as lavagens a membrana foi exposta às soluções de deteç̧ão 1 e 2 misturadas em igual volume. A quantidade de solução requerida foi de $0,125 \mathrm{ml} / \mathrm{cm}^{2}$ da membrana. Incubou-se por 1 minuto a temperatura ambiente.

Após a drenagem da solução de detecção, as membranas foram envolvidas em plásticos e exposta a um filme de raios $\mathrm{X}$ durante 10-60 minutos. Este filme foi então revelado e fixado seguindo-se a orientação do kit. 


\section{RESULTADOS E DISCUSSĀO}

$O$ isolamento do gene de resistência dominante ao metolachlor, em Saccharomyces cerevisiae é decorrente de um trabalho prévio desenvolvido no Laboratório de Genética de Leveduras, da ESALQ/USP, o qual envolveu o isolamento de mutantes via luz ultra violeta (ECHEVERRIGARAY et al., 1991).

A natureza monogênica do caráter foi determinada pela análise de tétrades permitindo assim, antever o potencial deste gene como marcador seletivo inclusive pela aplicação do método de seleção rápida e direta dos transformantes. Para garantir o sucesso da transformação, parâmetros como método seletivo eficiente e concentrações adequadas do agente seletivo foram estabelecidos. Os dados obtidos mostraram que a maioria das linhagens são resistentes a concentração de $720 \mathrm{mg} / \mathrm{l}$, enquanto que para a linhagem sensível AH22, utilizada como receptora do DNA exógeno, uma concentração de $144 \mathrm{mg} / 1$ foi suficiente para inibir totalmente o crescimento em meio sólido.

Comportamento distinto foi observado quando as linhagens foram crescidas em meio líquido, onde $72 \mathrm{mg} / 1$ foi suficiente para inibir o crescimento. Tais resultados justificam-se pois, em meio líquido e sob agitação, ocorre uma maior dispersão do herbicida aumentando assim a superfície de contato entre os componentes e a membrana celular.

\subsection{Clonagem do gene de resistência ao metolachlor}

Para a clonagem do gene utilizou-se fragmentos do DNA ao acaso, envolvendo a clonagem do tipo "shotgun". A construção do banco genômico em $E$. coli 
não foi necessária. $O$ processo de transformação foi rápido e eficiente por ser um gene de resistência dominante, possibilitanto a seleção direta dos clones.

A transformação de $S$. cerevisiae AH22 (ítem 3.11.1.1.) resultou em 10 clones selecionados diretamente em placas de YEPD (ítem 3.3.1.) acrescido de $720 \mathrm{mg} / 1$ de metolachlor. A tranformação obtida foi de baixa eficiência (1.0 transformante/ $\mu \mathrm{g}$ DNA), porém, este dado não foi relevante, uma vez que a obtenção de um único clone permitiria a continuidade dos experimentos, por se tratar de um marcador seletivo dominante.

Alguns autores acreditam que a baixa eficiência de transformação é devida ao marcador seletivo utilizado (HIEP et al., 1993; GALLEGO et al., 1993), outros desmonstram que a conformação do plasmídio favorece o processo (VIDAL \& GARBER, 1994) porém, existem outros que defendem a possibilidade de que o método empregado tem importância relevante no processo de transformação (MEILHOC et al., 1990; KASUKE et al., 1992) principalmente quando associados a alguns parâmetros, as quais podem gerar transformantes em um curto espaço de tempo (HIGGNS \& STRATHERN, 1991).

O método descrito no ítem 3.11.1.2. foi então empregado como forma comparativa e os resultados mostraram que a eficiência da transformação foi triplicada quando o método com incubação de células com PEG foi utilizado. Confirmou-se assim as hipóteses de BROZABOHATY \& KOVAK (1986) de que o PEG favorece a introdução do DNA plasmidial, embora os mecanismos envolvidos ainda não sejam conhecidos.

Apesar dos resultados acima, a transformação ainda apresentou-se com baixa eficiência e isto pode ser devido ao método empregado para a preparação da célula receptora, onde as células intactas ou esferoplastizadas podem ser utilizadas. A parede celular tem uma influência marcante na competência da célula para introdução do DNA, sendo que a eficiência $e$ aumentada quando se trabalha com células esferoplastizadas (BEGGS, 1978). Para tanto, a esferoplastização parcial pode ser empregada, porém é 
requerido um suporte osmótico para manter a integridade e a viabilidade celular (EVERETT et al., 1992). Outros métodos de transformação foram evitados por serem dispendiosos e propiciarem o surgimento de poliploidia e fusão celular, o que não é interessante quando linhagens industriais estão envolvidas (IIMURA et al., 1983; KOVAK, 1985).

O método de ITO et al. (1983) por mostrar-se mais eficiente foi empregado nas transformações posteriores.

Para extração de DNA os clones foram crescido em meio seletivo (YEPD $+720 \mathrm{mg} / 1$ de metolachlor). $O$ evento de transformação e posterior seleção constituemse num processo fisiológico e bioquímico extremamente desgastante para as células, podendo inclusive reduzir sua taxa de crescimento. Portanto, alguns autores (WEBSTER \& DICKSON, 1983), consideram importante um crescimento inicial somente em YEPD, para promover a revitalização dos mesmos. Apesar desta ressalva, foi possível realizar a extração de DNA, pois os clones apresentaram um bom crescimento.

Na eletroforese do DNA total, mostrada na Figura 3, não foi possível visualizar os plasmídios inseridos no genoma da levedura através da transformação. De acordo com LIVINGSTON (1977), plasmídios como o YEp 351 são encontrados na maioria das linhagens de $S$. cerevisiae em média de 55-100 cópias/célula, porém, aproximadamente $30 \%$ dos transformantes perdem o plasmídio depois de 15 a 20 gerações sob crescimento em meio não seletivo. Talvez esta instabilidade seja resultado de uma replicação competitiva com o plasmídio endógeno $2 \mu \mathrm{m}$, uma vez que este é muito estável (BUJEGA et al., 1989).

Com o intuito de amplificar o número de cópias de tais plasmídios para posteriormente isolar e caracterizar os mesmos, o DNA isolado dos 10 clones obtidos foi utilizado para transformação em $E$. coli (ítem 3.11.2.). Os resultados mostraram que nem todos os os DNAs foram capazes de transformar $E$. coli. Os 8 clones obtidos com a transformação foram provenientes de cerca de 2 clones de leveduras. Tal fato deveu-se a uma possível integração do gene ao DNA genômico, passando a se replicar como parte 
do mesmo. A mutação espontânea foi descartada devido a alta taxa de ocorrência. Outra hipótese foi uma eventual perda da origem de replicação do pBR 322, impossibilitando assim a sua replicação em $E$. coli (ORR-WEAVER et al., 1983).

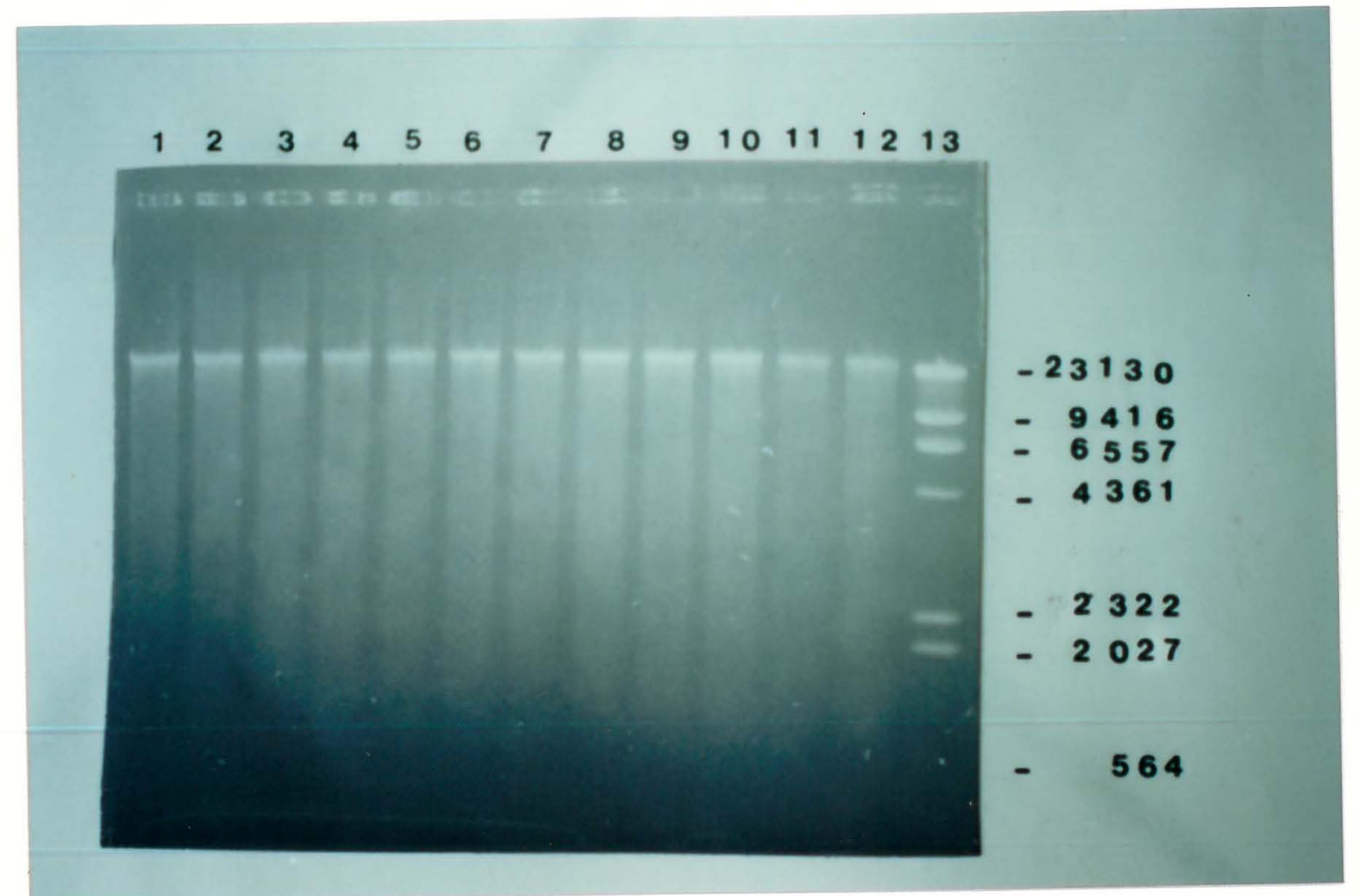

Figura 3. Eletroforese de DNA total dos clones de $S$. cerevisiae selecionados resistentes ao metolachlor. 1-10 clones recombinantes, 11 - S. cerevisiae AH22, 12linhagem resistente MD 3000, 13 - lambda/Hind III. 
Após a extração de DNA dos transformantes obtidos em $E$. coli DH alfa 5, o plasmídio pMTC 15 foi selecionado. Para confirmar a clonagem do gene metolachlor o plasmídio pMTC 15 foi utilizado para uma nova transformação em $S$. cerevisiae AH22 e o mesmo plasmídio foi recuperado após extração de DNA de clones retransformantes em E.coli.

A Figura 4 mostra que os clones transformantes foram selecionados em leveduras em duas etapas, inicialmente pela seleção direta em meio seletivo (ítem 3.3.1.) YEPD acrescido de $720 \mathrm{mg} / \mathrm{l}$ de metolachlor.

Uma outra alternativa para comprovar a presença do plasmídio no genoma da levedura foi transferir os clones selecionados em meio seletivo para meio mínimo (ítem 3.3.1.), isto porque, a linhagem sensível $S$. cerevisiae AH22 é auxotrófica para leucina. Porém, o plasmídio YEp 351 carrega o gene leu2, sendo que sua integração na célula restabelece o caráter prototrófico da linhagem.

Ainda na Figura 4 podemos observar a seleção procedida para clones transformantes em $E$. coli. Para esse fim foi realizada seleção direta dos transformantes em meio LB (ítem 3.3.2.) acrescido de $50 \mu \mathrm{g} / \mathrm{ml}$ de ampicilina. A bactéria DH alfa 5 não transformada não cresce em meio com ampicilina, portanto, os clones selecionados comprovaram a presença do plasmídio na bactéria, sendo que este contém o gene que confere resistência a este antibiótico. Outra confirmaçāo obtida da inserção do gene de resistência ao metolachlor é quando os mesmos clones foram inoculados em meio LB acrescido de ampicilina, IPTG e X-GAL. Tal experimento exprime o crescimento das colônias de coloração branca, confirmando que o gene ao inserir-se no plasmídio inativou o gene do lac $Z$, impedindo assim sua expressão a qual deveria promover o aparecimento de colônias azuis. 
4.1

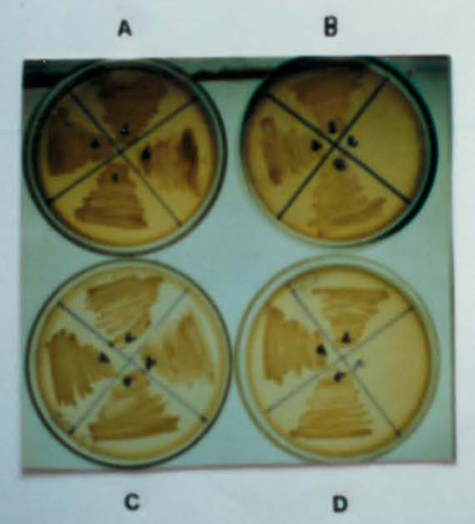

4.2

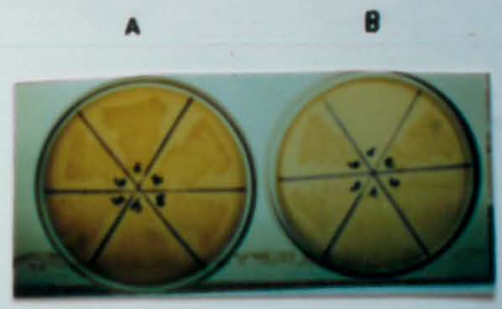

Figura 4.1. Crescimento das linhagens de $S$. cerevisiae transformadas.
1A. YEPD
1B. YEPD $+720 \mathrm{mg} / 1$ de metolachlor
1C. YNB $+20 \mu \mathrm{g} / \mathrm{ml}$ de leucina
1D. YNB

1 - Controle $S$. cerevisiae MD 3000; 2 - AH22; 3-4 - transformantes

Figura 4.2. Crescimento das linhagens de $E$. coli transformadas.

2A. LB

2B. $\mathrm{LB}+50 \mu \mathrm{g} / \mathrm{ml}$ de ampicilina

1 - Controle de $E$. coli DH alfa 5; 2-5 - transformantes. 


\subsection{Perfil eletroforético do plasmídio pMTC15}

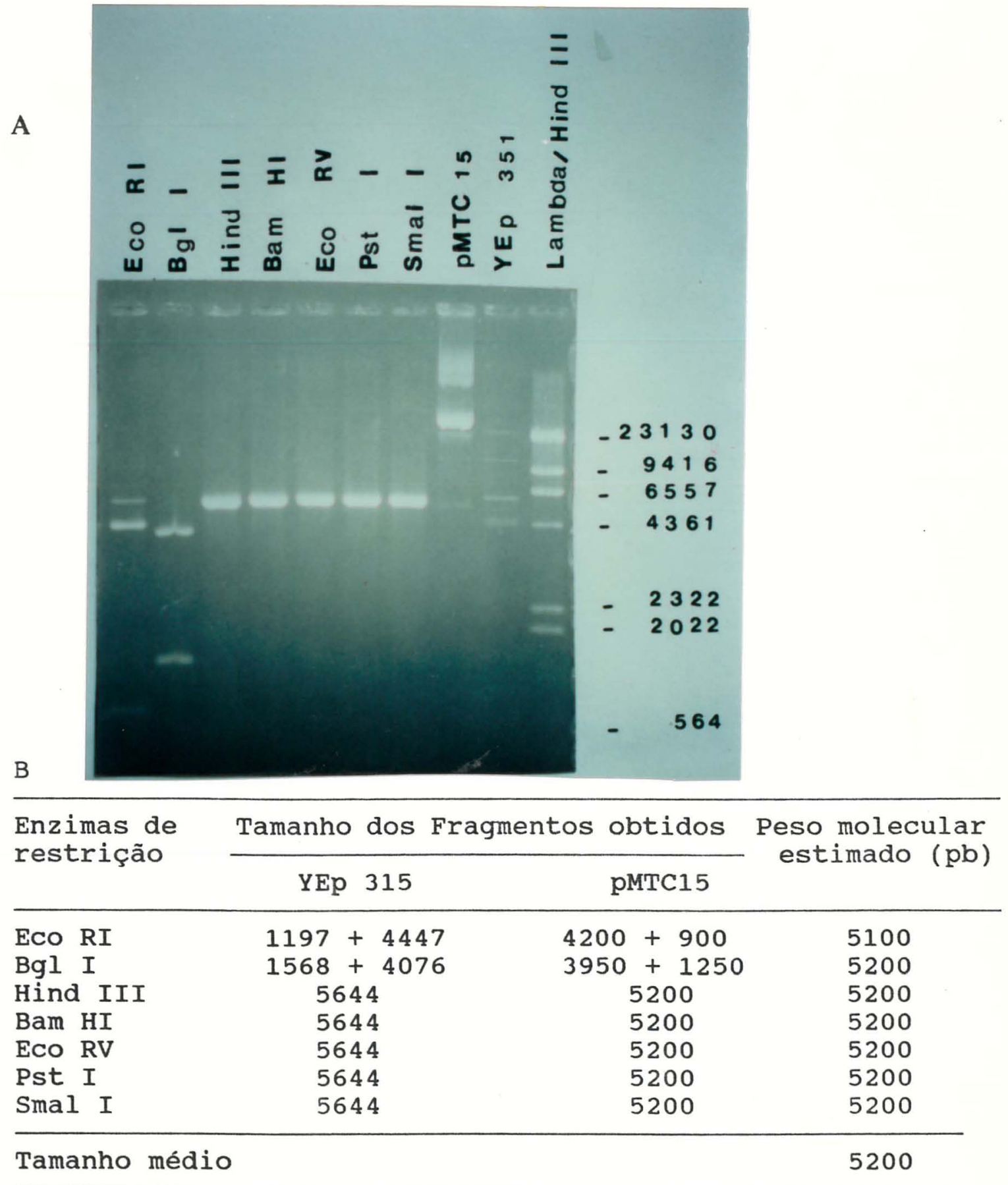

Figura 5. A. Perfil eletroforético do pMTC 15.

B. As enzimas utilizadas, os fragmentos obtidos e o peso molecular estimado. 
O plasmídio selecionado pMTC 15 (Figura 5), ao ser analisado em eletroforese de gel de agarose, apresentou um peso molecular de $5,2 \mathrm{~Kb}$ que é inferior ao vetor YEp $351(5,6 \mathrm{~Kb})$. A integridade do vetor plasmidial não foi verificada. Ocorreram alterações na molécula e a hipótese para explicar tal resultado seria a ocorrência de deleções e/ou rearranjos no vetor durante o processo de transformação. Os mecanismos envolvidos são desconhecidos, mas sugere-se que a linearização dos plasmídios estimula a frequência com que eles sofrem tais alterações (ORR-WEAVER et al., 1983).

A análise dos sítios confirmou as alterações nos padrões de restrição do plasmídio. Não se sabe exatamente onde estas deleções ocorreram, porém é assegurado que os sítios que possuem marcas seletivas (a região de ori de E.coli, o gene amp, o gene leu2 e o $2 \mu \mathrm{m}$ de levedura) não foram alterados. Ao comparar os sítios de restrição do pMTC 15 com o do YEp 351 observou-se alterações no tamanho dos fragmentos de EcoRI e BglI.

A ocorrência de alterações na molécula de DNA plasmidial dificultou analisar os sítios de restrição, não permitindo localizar o gene $m t c l$ e, nem tão pouco, construir seu mapa de restrição. Para isto serão necessárias digestões duplas e ou triplas, visando uma melhor caracterização.

Apesar disso podemos dizer que o gene $m t c l$ encontra-se num fragmento de $1.3 \mathrm{~Kb}$ liberado pela enzima $b g l I$, a qual origina dois fragmentos, um com $3.8 \mathrm{~Kb}$ e outro com $1.3 \mathrm{~Kb}$, sendo este último utilizado como sonda nos processos de hibridização a seguir, confirmando assim a presença do gene $m t c 1$.

\subsection{Transformação de outras linhagens de $S$. cerevisiae}

Linhagens sensiveis ao metolachlor e de interesse industrial foram transformadas com o objetivo de avaliar a capacidade de transformação do plasmídio pMTC 15. A hipótese de alguns autores (BEGGS, 1978; STRUHL et al., 1979) de que 
a eficiência da transformação depende da interação plasmídio/hospedeiro e de que existe uma singularidade entre as linhagens quanto a sua capacidade de receber e expressar um DNA heterólogo foi confirmada.

Os transformantes foram selecionados diretamente em meio seletivo acrescido de metolachlor $(720 \mathrm{mg} / \mathrm{ml})$.

Segundo BUJEGA et al. (1989) condições fisiologicas e ambientais influem na eficiência da transformação genética de certas linhagens, pois a habilidade que uma linhagem possui em ser transformada é singular, dependendo principalmente do seu genótipo. Este pode interferir na expressão de um marcador seletivo, pois a resposta a um determinado marcador é um fator específico da linhagem.

Os resultados da Tabela 3 coincidem com os discutidos por BRUSCHI et al. (1987), onde encontramos linhagens que apresentam alto número de transformantes e outras que não transformam. A diferença na transformação das linhagens é bastante acentuada. Neste trabalho, o mais alto nível de transformação foi obtida pela linhagem M 304-2C e houveram linhagens que apresentaram níveis intermediários como a M 300 A, a GRF 18 e AH22. Não foram obtidos transformantes da linhagem X-2180 1B.

Tabela 3. Transformação de outras linhagens de $S$. cerevisiae usando $10 \mu \mathrm{g}$ de DNA do plasmidio pMTC 15.

\begin{tabular}{llc}
\hline Linhagem & & Número de clones \\
\hline S. cerevisiae & AH22 & 11 \\
S. Cerevisiae & GRF-18 & 10 \\
S. Cerevisiae & M304-2C & 50 \\
S. Cerevisiae & M300A & 25 \\
S. cerevisiae & X-2180-1B & 0 \\
\hline
\end{tabular}




\subsection{O grau de resistência dos clones}

Com o intuito de verificar o a hipótese de SANGLARD \& FLECHTER (1992), de que os níveis de resistência podem estar relacionados ao número de cópias do vetor presente na célula e/ou a forma pelo qual este gene vem sendo expressado, o nível de resistência dos clones de diferentes linhagens foram avaliados.

A Tabela 4 mostra que o mesmo plasmídio expressou-se de maneira distinta entre as linhagens reforçando a idéia de BUJEGA et al. (1989), de que condições fisiológicas e ambientais interferem na habilidade que cada linhagem têm de receber e expressar o DNA exógeno. A linhagem AH22, não transformada e utilizada como controle negativo, teve seu crescimento interrompido numa concentração de $72 \mathrm{mg} / \mathrm{l}$. A linhagem resistente MD 3000 juntamente com os transformantes da linhagem AH22 e M 300A cresceram satisfatoriamente até uma concentração de $288 \mathrm{mg} / 1$. Já os transformantes da linhagem M 304-2C foram resistentes até $720 \mathrm{mg} / 1$.

As diferenças observadas nos níveis de resistência entre as linhagens reiteram as observaçōes feitas por BUJEGA et al. (1989) quanto a afinidade singular entre vetor/hospedeiro.

Apesar das alterações sofridas na sua estrutura, o plasmídio pMTC 15 não teve sua expressão dificultada, porém a diferença no crescimento em meio líquido permite supor que o número de cópias do plasmídio presente na célula foi variável. 
Tabela 4. Grau de resistência dos clones ao metolachlor. Crescimento em meio líquido.

\begin{tabular}{lcccccc}
\hline & \multicolumn{6}{c}{ Metolachlor (mg/l) } \\
\cline { 2 - 7 } Transformantes & 0 & 72 & 144 & 216 & 288 & 720 \\
\hline Controle & + & - & - & - & - & - \\
MD 3000 & + & + & + & + & +- & - \\
AH22 T⿱艹 & + & + & + & + & + & - \\
M 300 A T* & + & + & + & +- & +- & - \\
M 304-2C T* & + & + & + & + & + & +- \\
\hline
\end{tabular}

* Transformante

\subsection{A instabilidade mitótica dos plasmídios}

De acordo com SREEKRISHNA et al. (1987) é pela estabilidade dos plasmídios que se avalia a utilidade de uma levedura recombinante. Sendo assim selecionar plasmídios com alta estabilidade na ausência de pressão seletiva e com alto número de cópias é um fator muito importante, principalmente quando a finalidade é atender as necessidades industriais, as quais visam diminuir os custos quanto a utilizaçào de mecanismos seletivos durante o processo, que em geral são dispendiosos.

Os resultados mostraram que o crescimento do plasmídio pMTC $15 \mathrm{em}$ meio não seletivo influenciou acentuadamente na instabilidade fazendo com que ocorresse perda de $70 \%$ dos plasmídios após uma média de 100 gerações. Provavelmente fatores fisiológicos e genéticos interferiram na estabilidade dos plasmídios.

Pelo fato do plasmídio em questão ser originário do plasmídio $2 \mu \mathrm{m}$, a instabilidade verificada pode ser devido a presença do plasmídio endogeno $2 \mu \mathrm{m}$, que E capaz de interferir na estabilidade por competir com os plasmídios quiméricos (FUTCHER \& COX, 1984). 
Outra hipótese é a ocorrência da instabilidade segregacional dos vetores epissonais, cujo resultado é uma distribuição assimétrica entre as células mãe e filha durante as gerações sucessivas (MURRAY \& SZOSTAK, 1983).

\subsection{Experimentos realizados na separação de DNA cromossômico de leveduras em eletroforese em campo pulsado (CHEF)}

Com a utilização de métodos genéticos, o gene de resistência ao metolachlor foi previamente mapeado no cromossomo XV da levedura. Tal resultado é decorrente de experimentos anteriores desenvolvidos no Laboratório de Genética de Leveduras da ESALQ/USP.

Nesta etapa do trabalho foi realizada a localização física do gene de resistência ao metolachlor no genoma da levedura, utilizando a metodologia de bandeamento eletroforético de DNA cromossomal e a hibridização.

A eletroforese em campo pulsado previamente desenvolvida em Saccharomyces cerevisiae vem sendo aprimorada, permitindo a obtenção de bandas cromossômicas de vários microrganismos (MAGEE \& LEONG, 1988; BERGKAMP et al., 1991; ALLEGRUCCI et al., 1993). Do mesmo modo, alguns autores (Mc CLUSKEY et al., 1990; MILLS, 1990; GARDNER et al., 1993) tem buscado simplificar a etapa de preparação das amostras do DNA cromossômico.

Com o intuito de otimizar o método para obtenção das amostras de DNA genômico de leveduras, métodos distintos foram experimentados e todos produziram resultados satisfatórios.

A Figura 6 mostra o perfil eletroforético do DNA cromossômico da linhagem MD 3000 resistente ao metolachlor, expresso em 12 bandas cromossômicas. Os experimentos realizados visando obter melhor definição de bandas envolveram várias modificações da metodologia de preparo da amostra. A seguir serão discutidas as 
peculiaridades de cada um dos métodos e o motivo pelo qual o quinto método foi escolhido para os experimentos posteriores.

O experimento 1 segue o protocolo de SCHWARTZ \& CANTOR (1984) com modificações no processo de protoplastização, onde a enzima liticase não foi necessária. Esse experimento além da obtenção dos protoplastos, inclui também o tratamento de um dia com detergentes (ítem 3.5.20.), cuja função $e$ quebrar as pontes de enxofre entre as proteínas e um dia com enzimas proteolíticas (ítem 3.5.14.) para a degradação das proteínas da parede celular, seguido de três lavagens consecutivas em tampão específico (ítem 3.5.13.) durante 15 minutos e ressuspensão no mesmo. A otimização no processo de lavagem reduziu de 3 para 2 dias a preparação das amostras.

0 experimento 2 tem modificações na protoplastização quanto a molaridade do tampão de lavagem e ressuspensão, o qual passou de $50 \mathrm{mM}$ para $10 \mathrm{mM}$ pH 8,0. A enzima para digestão da parede celular utilizada foi a Zymolyase 5000 (2 $\mathrm{mg} / \mathrm{ml}$ ). O tratamento foi reduzido para um dia, dispensando o tratamento com detergentes (tampão LET, ítem 3.5.20.).

O experimento 3 utilizou células intactas seguindo o tratamento com detergentes por 2 horas e com enzimas proteolíticas "overnight". As amostras foram preparadas em um dia.

O experimento 4 , assim como o experimento 3 , não requer a remoção da parede celular e mantem o tratamento com tampão NDS (3.5.10.). Entretanto exclui o tratamento com tampão LET (ítem 3.5.20.). Apenas um dia foi requerido para a preparação das amostras.

Os experimentos 3,4 e 5 seguiram a hipótese de McCLUSKEY et al., 1990 e GARDNER et al., 1993 de que a obtenção de protoplastos não é necessária. Porém o $5^{\circ}$ experimento incluiu o tratamento com acetato de lítio para facilitar a saŕda do DNA da célula, já que são utilizadas células intactas.

Segundo ITO et al. (1983) o tratamento com acetato de lítio constitui-se numa técnica que permeabiliza a parede celular. As razões pelas quais o cátion lítio 
favorece a entrada de DNA nas células de levedura não estão bem conhecidas (BRZOBOHATY \& KOVAC, 1986), provavelmente este efeito permeabilizante favoreça também o processo inverso como é sugerido neste trabalho.

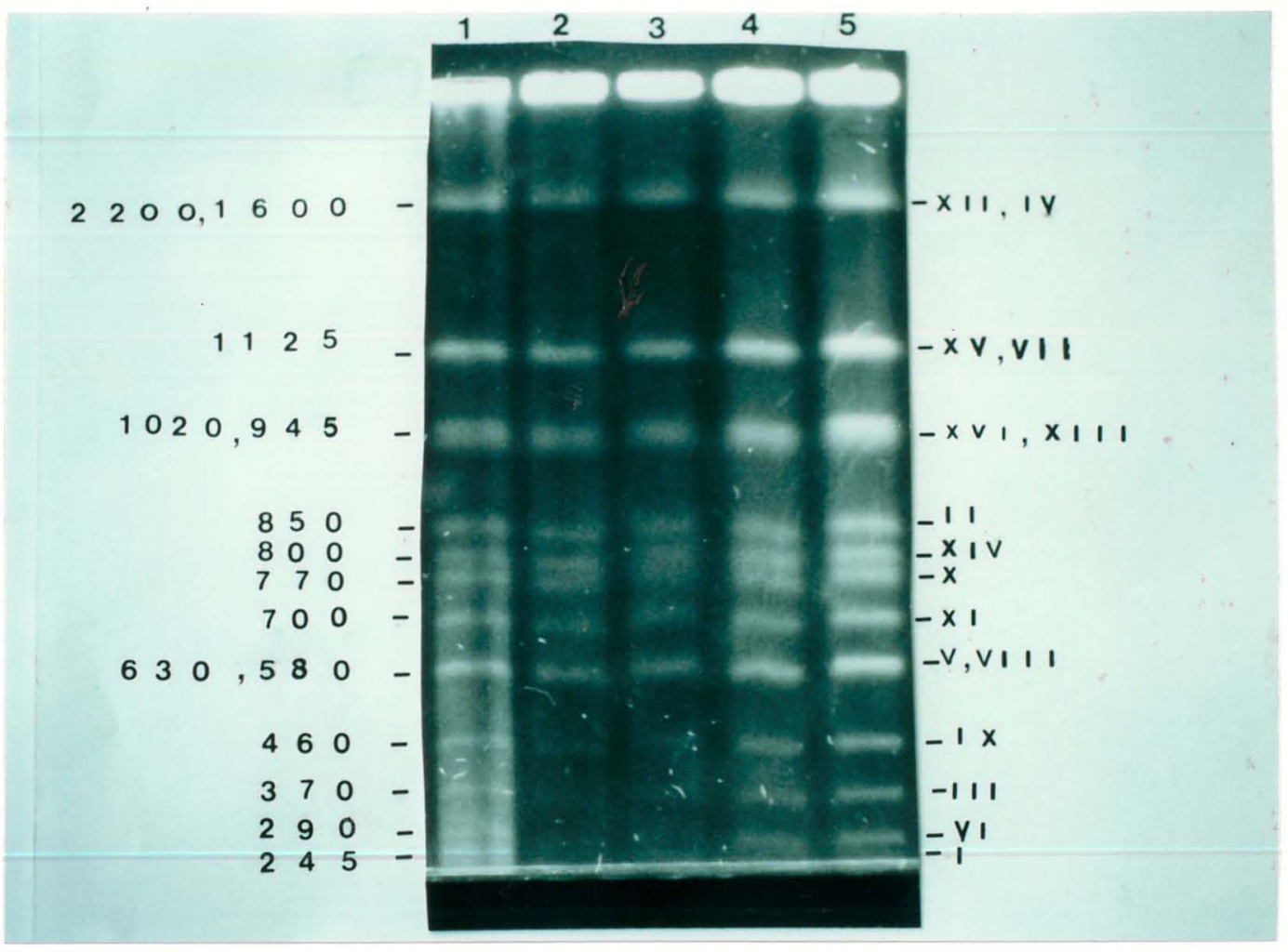

1 - Experimento 1

2 - Experimento 2

3 - Experimento 3

4 - Experimento 4

5 - Experimento 5

Figura 6. Experimentos realizados em eletroforese de campo pulsado (CHEF) com os cromossomos de $S$. cerevisiae MD 3000 . Tempo de corrida totalizando 23 horas. 
Experimentos realizados substituindo o acetato de lítio (LiAc) pelo acetato de potássio (KAc), permitiram inferir que ambos os cátions monovalentes sensibilizam a parede celular da levedura favorecendo a saída do DNA da célula (Figura 7).

Dentre os métodos alternativos citados neste trabalho, o quinto método foi empregado nos experimentos que se seguiram (Figura 7). Isto porque, além de ser obtido num menor espaço de tempo é também muito prático, simples, barato e eficiente, emergindo como o mais adequado, pois é capaz de apresentar um melhor padrão de definição de bandas (Figura 6), além de se mostrar efetivo para a obtenção do perfil eletroforético do DNA de várias linhagens de Saccharomyces cerevisiae (Figura 7).

Para comprovar a eficiência do quinto método, outras linhagens de $S$. cerevisiae foram utilizadas.

A Figura 7 mostra que foi possível obter o padrão de bandas de todas as linhagens de S. cerevisiae utilizadas (1904; Fleischmann; M 300A; AH22; M304-2C e MD 300), porém podemos observar polimorfismos de bandas entre as linhagens industriais. A linhagem Fleischmann teve um número maior de bandas definidas no total de 14, enquanto as linhagens MD 3000 e AH22 tiveram 13 bandas distinguidas. As linhagens 1904, M 300-A e M 304-2C tiveram somente 12 bandas distintas. Estes resultados reforçam a hipótese de CANTOR et al. (1988) de que alguns parâmetros podem melhorar a resolução do cariótipo eletroforético. Nesse caso, o parâmetro modificado foi o tempo de corrida que aumentou em 1 hora durante o pulso de 90 segundos, totalizando 24 horas de corrida.

Grande grau de polimorfismo tem sido notado em fungos e leveduras (SKINNER et al., 1990; ORBACH. 1989; MASEL et al.m 1990). Alguns autores observaram eventos de translocações, duplicações e deleções entre linhagens polimórficas (ADAMS et al., 1992). É sugerido que tais modificações estruturais no genoma destes microrganismos indicam ocorrência de adaptação genética ao meio ambiente. 


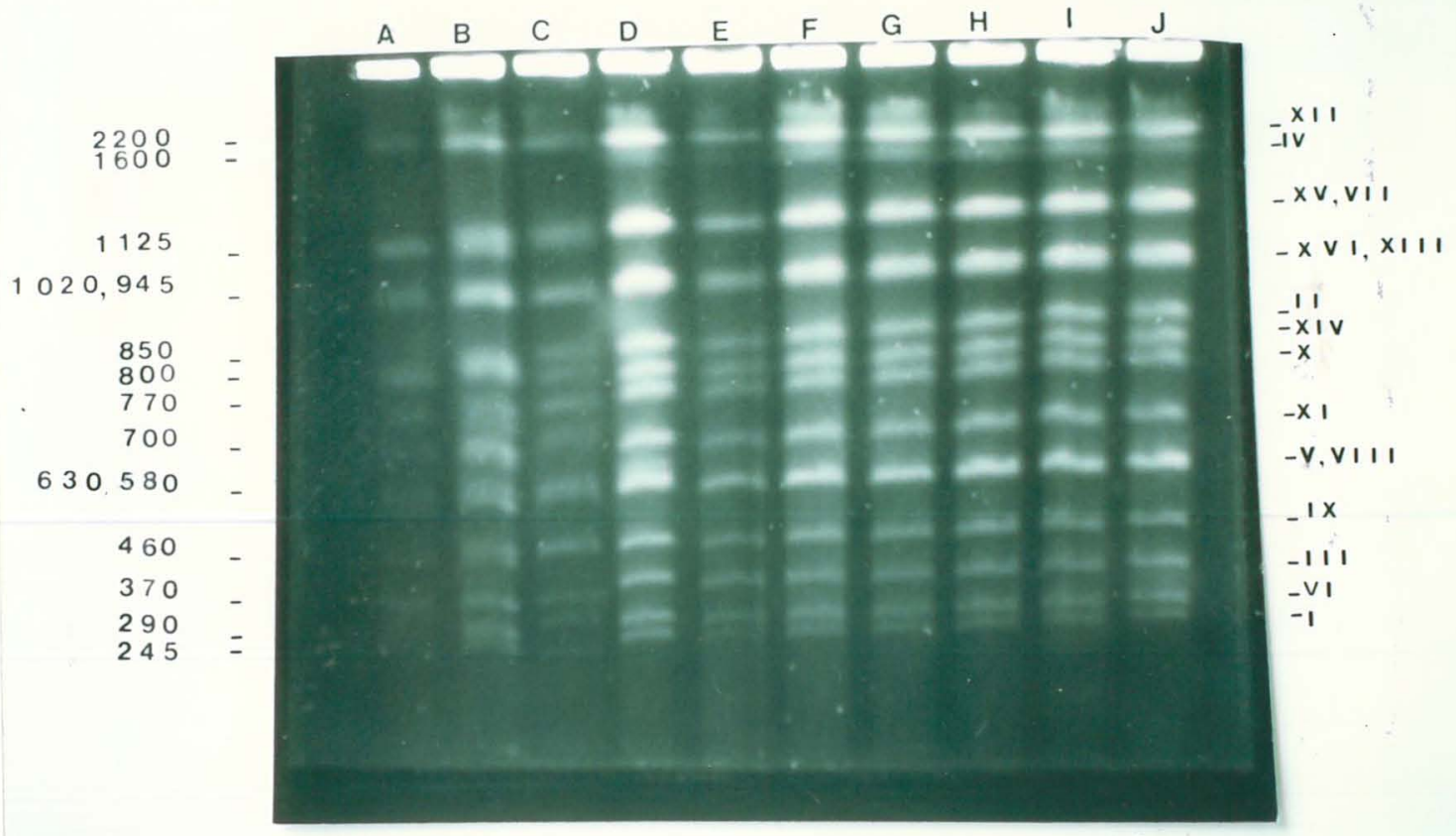

Figura 7. Eletroforese em campo pulsado de várias linhagens de S. cerevisiae. A) 1904; B) Fleischmann; C) M 300A; D) AH22; E) M 304-2C; F-H) MD 3000 (LiAc); I-J) MD 3000 (KAc). Tempo de corrida 24 horas. 


\subsection{Localização do gene MTC 15 pela hibridização com DNA cromossomal através de eletroforese em campo pulsado}

A localização de genes através de hibridização com DNA cromossômico foi feita em várias espécies de microrganismos (MONTENEGRO et al., 1992; BERGKAMP et al., 1991; MASEL et al., 1990).

Com a finalidade de confirmar o mapeamento do gene de resistência ao metolachlor no cromossomo XV da levedura seguimos a sugestão de BRODY et al. (1991) onde, após a separação do DNA cromossômico a banda correspondente ao cromossomo XV, VII e XVI, XIII foi cortada e por eletroeluição (3.17.) o DNA foi retirado do gel e purificado.

Dando continuidade ao trabalho procedeu-se a preparação da membrana de nylon, aplicando-se a técnica de "Dot blot" (3.8.1.), onde alíquotas de $20 \mu 1$ de DNA correspondente ao cromossomo XV de várias linhagens resistentes ao metolachlor foram aplicadas na membrana. Foi usado como controle negativo o DNA correspondente ao cromossomo XIII e XVI da linhagem sensível AH22 e de outras linhagens de $S$. cerevisiae resistentes e como sonda o plasmídio pMTC 15.

A Figura 8A mostra que após a hibridização com a sonda molecular e exposição do filtro contra um filme de raio $X$, foi possível observar um forte sinal de hibridização nas regiōes pertencentes as linhagens resistentes ao metolachlor, porém houve o aparecimento de hibridização inespecifica na região correspondente à linhagem sensível. Frente a este resultado, a estringência das condições de hibridização e lavagem foi aumentada. A temperatura passou de $42^{\circ} \mathrm{C}$ para $45^{\circ} \mathrm{C}$ nas etapas de pré-hibridização, hibridização e lavagens. $O$ tempo de lavagem primária foi aumentado de 10 para 15 minutos. Após a exposição da membrana ao filme de raio-X verificou-se que a hibridização não-específica não ocorreu (Figura 8B). Entretanto esta hibridização não especifica Figura 8A era esperada por tratar-se de uma mutação no gene conferindo a resistência ao metolachlor. 

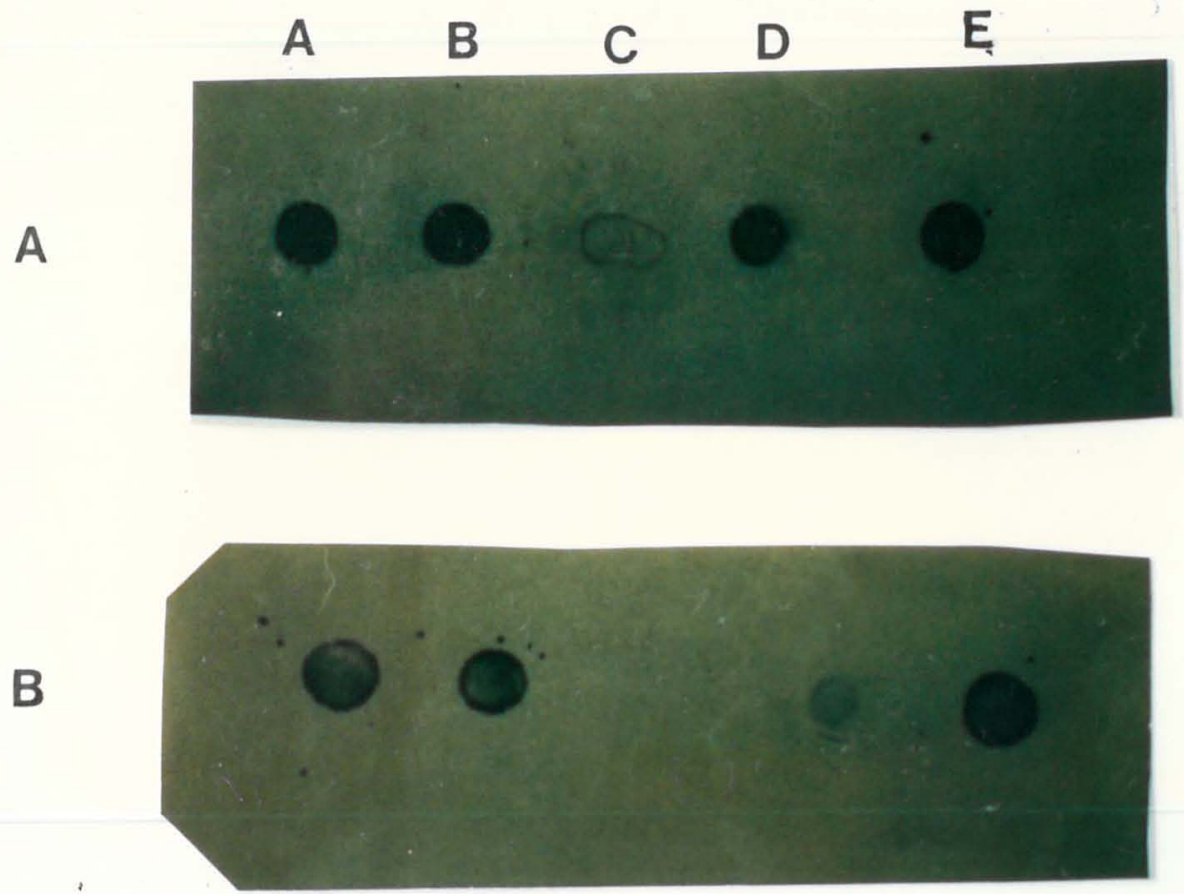

Figura 8. Autoradiografia resultante da hibridização do plasmídio pMTC 15 com o cromossomo XV de S. cerevisiae. A) MD 3000; B) AH22 R; C) AH22 s; D) M 3000; E) AH22 R. 
Visando descartar a hipótese de uma possível translocação do gene correspondente ao leu2 e/ou $2 \mu \mathrm{m}$ para os cromossomos XV e VII e também para reforçar a clonagem do gene mtcl no plasmídio pMTC15; o trabalho foi conduzido realizando a eletroeluição (ítem 3.17.) do fragmento $1.3 \mathrm{~Kb}$ do pMTC 15 , É sugerido que neste fragmento haja somente uma sequência homóloga ao genoma da levedura, a sequência correspondente ao gene de resistência ao metolachlor. Após o isolamento e purificação do fragmento do DNA em questão, este foi utilizado como sonda nos processos de hibridização que se seguem.

Após a hibridização a membrana foi exposta novamente ao filme de raio $X$, e este revelou o resultado esperado. Houve hibridização específica nas regiões correspondentes às linhagens de $S$. cerevisiae resistentes ao metolachlor (MD 3000, AH22 R, M 3000 R, M 304-2C R) e não foi verificado qualquer sinal de reação nas regiões correspondentes ao cromossomo XVI e XIII da linhagem sensível AH22 e de outras linhagens resistentes (AH22, M 300 A, M 304 2C e MD 3000) (Figura 9).

É pertinente ressaltar que o DNA total das linhagens resistentes ao metolachlor poderia ser utilizado nos processos de hibridização, porém, como medida de estringência e para evitar dúvidas quanto a região de homologia prosseguimos de acordo com o que foi demonstrado. 


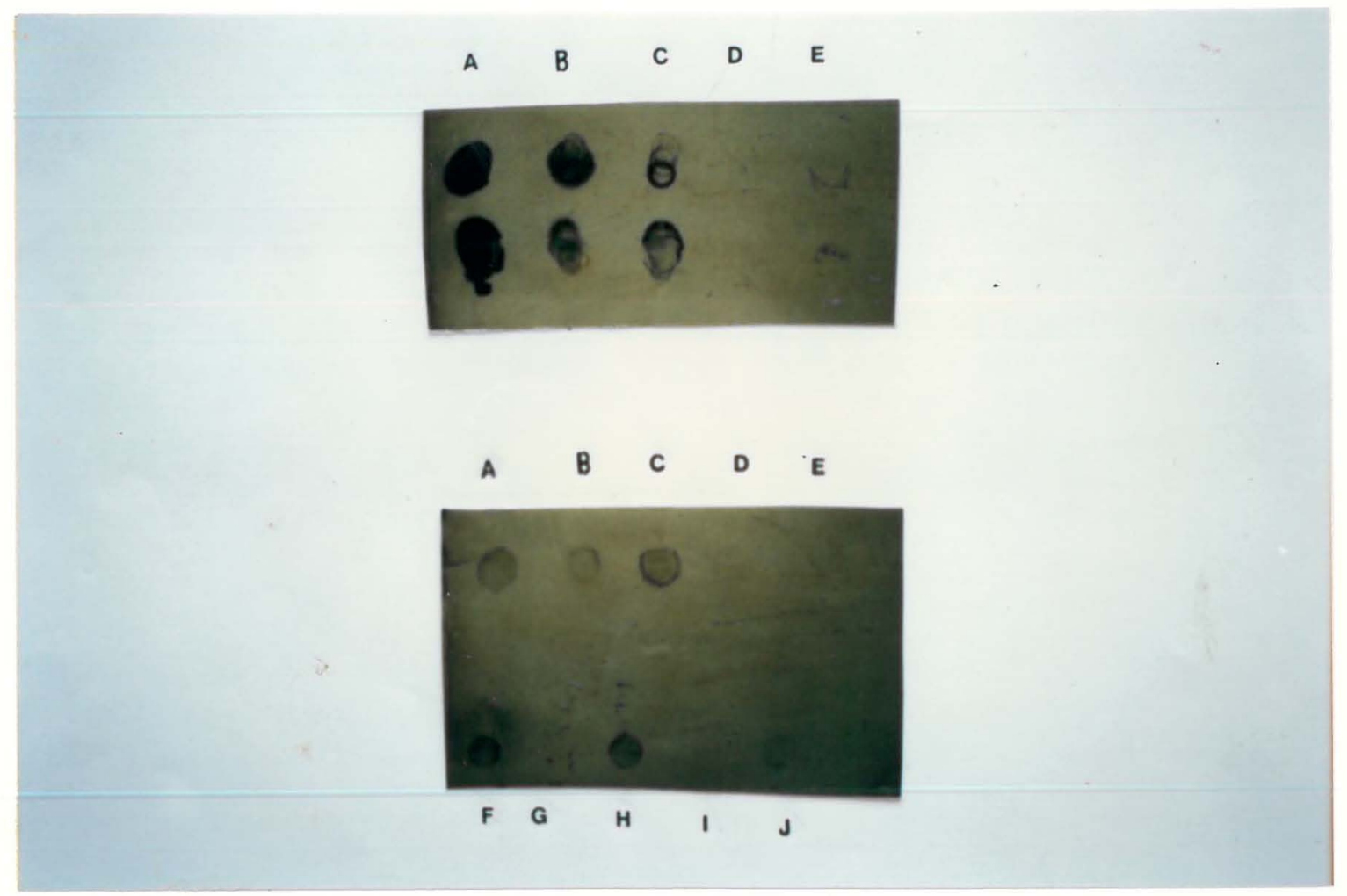

Figura 9. Autoradiografia resultante da hibridização do fragmento do pMTC 15 com os cromossomos XV e XIII/XVI de $S$. cerevisiae. 1A) MD $3000 \mathrm{R}(\mathrm{XV})$; 1B) AH22 R (XV); 1C) AH22 R (XV); 1D) AH22 R (XIII/XVI); 1E) M 300 A R (XV); 2A) M 300 2C R (XV); 2B) M 30A R (XV); 2C) MD 3000 (XV); 2D) MD 3000 (XIII/XVI); 2E) MD 3000 (XIII/XVI); 2F) MD 3000 (XV); 2G) M 304-2C R (XIII/XVI); 2H) AH22 R (XV); 2I) AH22 R (XIII/XVI); 2J) M 300A R (XV). 
Novos trabalhos podem ser sugeridos para complementação dos estudos até aqui encaminhados, os quais podem visar a caracterização e sequenciamento do gene em questão, facilitando a compreensão da sua estrutura e funcionamento e por conseguinte a ação e os efeitos do gene $m t c 1$ nas células de leveduras. 


\section{CONCLUSÃo}

Os resultados obtidos no presente trabalho permitem concluir que:

0 trabalho de clonagem do gene de resistência ao metolachlor no plasmídio pMTC15 contribui para o processo de seleção de transformantes em leveduras, onde o número de marcadores seletivos dominantes é escasso. A alta instabilidade mitótica observada pode ser resultado da competição entre o plasmídio quimérico e o plasmídio endógeno $2 \mu \mathrm{m}$ e/ou devido a uma distribuição assimétrica entre a célula mãe e filha nas divisões celulares. Para separação de cromossômos de $S$. cerevisiae o tratamento de células intactas com LiAc foi o método mais adequado neste trabalho. Utilizando-se a técnica de eletroforese em campo pulsado e hibridização, o gene de resistência ao metolachlor foi localizado no cromossomo XV da levedura $S$. cerevisiae, confirmando-se dados genéticos previamente obtidos. 


\section{REFERÊNCIAS BIBLIOGRÁFICAS}

ABRAHAM, P.R.; MULDER, R.A.; RIET, J.V.; PLANTA, R.J.; RAVE, H.A. Molecular cloning and physical analysis of on $82 \mathrm{~Kb}$ segment of chromosome XI of Saccharomyces cerevisiae reveals fine tightly linked genes. Yeast, Chichester, 8: 227-238, 1992.

ADAMS, J.; PUSKAS-ROZZA, S.; SIMLAR, J.; WILKE, C.M. Adaption and major chromosonal changes in populations of Saccharomyces cerevisiae. Current Genetics, Berlin, 22: 13-9, 1992.

ALLEGRUCCI, M.; LANFALONI, L.; BIETTA, C.; SPACCAPELO, R.; FIORETTI, M.C.; BISTONI, F. The electrophoretic karyotype of two strains of Candida albicans by transverse alternate field electrophoresis reveals higher number of chromosomes ranging from 1 to $35 \mathrm{Mb}$. Yeast, Chichester, 9: 1213-8, 1993.

BANCROFT, I. \& WOLK, C.P. Pulsed homogeneous orthogonal field gel electrophoresis (PHOGE). Nucleic Acids Research, Oxford, 16: 7405-18, 1988.

BEGGS, J.D. Transformation of yeast by a replicant hydric plasmid. Nature, London, 275: 104-9, 1978.

BERGKAMP, J.M.; GEERSE, R.H.; VERBAKEL, J.M.A.; MUSTERS, W.; PLANTA, R.J. Cloning and disruption of the leu2 gene of Kluyveromyces marxianus CBS 6556. Yeast, Chichester, 7: 963-70, 1991. 
BERGKAMP, J.M.; GEERSE, R.H.; VERBAKEL, J.M.A.; PLANTA, R.J. Cloning and sequencing of the ura3 gene of Kluyveromyces marxianus CBS 6556. Yeast, Chichester, 9: 677-81, 1993.

BIDENNE, C.; BLONDING, B.; DEQUIM, S.; VEZINHET, F. Analysis of the chromosonal DNA polymorphism of wine strain of Saccharomyces cerevisiae. Current Genetics, Berlin, 22: 1-7, 1992.

BRODY, H. \& CARBON, J. Electrophoretic karyotype of Aspergillus nidulans. Proceeding of the National Academy of Science U.S.A., Washington, 86: 6260-3, 1989.

BRODY, H; GRIFFITH, J.; CUTICCHIA, A.J.; ARNOLD, J. \& TIMBERLAKE, W.E. Chromosome-specific recombinant DNA libraries from the fungus Aspergillus nidulans. Nucleic Acids Research, Oxford, 19: 3105-08, 1991.

BRUSCHI, C.V.; COMER, A.R.; HOWE, G.A. Specificity of DNA uptake during whole cell transformation of $S$. cerevisiae. Yeast, Chichester, 3: 131-7, 1987.

BRZOBOHATY, B. \& KOVAC, L. Factors enhancing genetic transformation of intact yeast cells modify cell wall porosity. Journal General Microbiology, London, 132: 30-93, 1986.

BUJEGA, V.C.; KLEINMAN, J.; SATAMBURY, P.F.; GINGOLD, E.B. The segregation of the $2 u$-based yeast plasmid pJDB248 breaks down under condictions of slow glucose-limited growth. Journal General Microbiology, London, 135: 22801-7, 1989. 
BURKE, D.J.; CARLE, G.F.; OLSON, M.V. Cloning of large segments of exogeneous DNA into yeast by means of atificial chromosome vectors. Science, Washington, 260: 806-12, 1987.

CANTOR, C.R.; SMITH, C.L.; MATHEW, M.K. Pulsed-field gel electrophoresis of very large DNA molecules. Annual Review Biophysics and Biophysical Chemistry, Palo Alto, 17: 287-304, 1988.

CARLE, G.F. \& OLSON, M.V. Separation of chromosomal DNA molecules from yeast by orthogonal-alternation gel electrophoresis. Nucleic Acids Research, Oxford, 12: 5647-64, 1984.

CARLE, G.F.; FRANK, M.; OLSON, M.V. Electrophoretic separations of large DNA molecules by periodic inversion of the electric field. Science, Washington, 232: 65-8, 1986.

CARTY, C.E.; HOFMANN, K.J.; KELLER, P.M.; POLOKOFF, M.A.; LYNCH, R.J.; KEECH, B.J.; SCHULTZ, L.D. Regulated production of recombination echistatin by yeast. Biotechnology Letters, Kew, 12: 79-84, 1990.

CASEY, G.P.; XUAO, W.; RANK, G.H. A convenient dominant selection marker for gene transfer in industrial strain of Saccharomyces yeast: smrl encoded ressistance to the herbicide sulfometuron methyl. Journal of the Institute of Brewing, London, 94: 93-7, 1988.

CHU, G.; VOLLRATH, D.; DAVIS, R.W. Separation of large DNA molecules by contour-clamped homogeneous eletric fields. Science, Washington, 234: 1582-5, 1986. 
CHU, G. \& GUNDERSON, K. Separation of large DNA by a Variable Angle ContourClamped Homogeneous Electric Field Apparatus. Analytical Biochemistry, Duluth, 194: 439-46, 1991.

CLARK, S.M.; LAI, E.; BIRREN, B.W.; HOOD, L. A novel instrument for separating large DNA molecular with pulsed homogeneous electric fields. Science, Washington, 241: 1203-5, 1988.

CLARKE, L. \& CARBON, J. Isolation of a yeast centromer and construction of a functional samll circular chromossome. Nature, London, 287: 504-9, 1980.

DE JONGE, P.; DE JONGH, F.C.M.; MEIJERS, H.; STEENSMA, Y.; SCHEFFERS, W.A. Orthogonal-field-alternation gel electrophoresis banding patterns of DNA from yeast. Yeast, Chichester, 2: 193-204, 1986.

DEWAR, K.; BERNIER, L. Eletrctrophoretic of the elm tree pathogen Ophiostoma ulmi (sensu lato). Molecular \& General Genetics, Berlin, 38: 43-8, 1993.

DODGE, A.D. The mode of action of herbicides. In: HUSTON, D.H. \& ROBERTS, T.R. eds. Progress in pesticide biochemistry and toxicology, New York, 3: 163-7, 1983.

DROCOURT, D.; ClAMELS, T.; REYNES, J.P.; BARON, M.; TIRABY, G. Cassets of the Streptoalloteichus hindustanus ble gene for transformation of lower and higher eukaryotes to phleomycin resistance. Nucleic Acids Research, Oxford, 18: 1792-6, 1990. 
ECHEVERRIGARAY, S.; TAVARES, F.A.C.; GOMES, L.H.; BOSCARIOL, F.C. Inhibition of yeast groeth by herbicides. Ciência e Cultura, São Paulo, 43(6): 457-9, 1991.

ELLIOT, S. Eukaryotic expression vectors. In: RODRIGUES, R.L. \& DENHARDT, D.T., (ed.) Vectors: a survey of molecular cloning vectors and their uses. Butterworth, London, 1988, cap.1, p.66-88.

EVERETT, J.G. \& GALLIE, D.R. RNA delivery in Saccharomyces cerevisiae using eletroporation. Yeast, Chichester, 8: 1007-17, 1992.

FALCON, S.C. \& DUMAS, R.S. Genetic analysis of mutant of Saccharomyces cerevisiae resistant to the herbicide sulfometuron methyl. Genetics, Princeton, 109: 21-35, 1985.

FOGEL, S. \& WELCH, J.W. Tanden gene aplification mediates copper resistance in yeast. Proceeding of the National Academy Science USA, Washington, 79: $4532-6,1982$.

FUTCHER, A.B. \& COX, B.J. Copy number and the stability of $2 \mu \mathrm{m}$ circle-based artificial plasmids of Saccharomyces cerevisiae. Journal of Bacteriology, Baltimore, 157: 283-90, 1984.

GALLEGO, C.; CASAS, C.; HERRERO, E. Increased transformation levels in intact cells of Saccharomyces cerevisiae Aculeacin A-resistent mutants. Yeast, Chichester, 9(5): 523-6, 1993. 
GARDINER, K. \& PATTERSON, D. Transverse alternating electrophoresis. Nature, London, 331: 371-2, 1988.

GARDINER, K.; LASS, W.; PATTERSON, D. Fractionation of large mamalian. DNA restricition fragments using pulsed-field gradient gel electrophoresis. Somatic Cell Molecular Genetics, New York, 12: 185-95, 1986.

GARDINER, D.C.J.; HEALE, S.M.; STATEVA, L.I.; OLIVER, S.G. Treatment of yeast cells with wall lytic enzymes is not required to prepare chromosomes for pulsed-field. Yeast, Chichester, 9: 1053-6, 1993.

GATINOL, A.; DASSAN, M.; TIRABY, G. Cloning of Saccharomyces cerevisiae promoters using a probe vector based on phleomycin resistance. Gene, Amsterdan, 91: 35-41, 1990.

GELLINSEN, G.; STRASSER, A.W.; MELBERKEUP, P. Die methlotrophe hefe $\boldsymbol{H}$. polymorpha cels expression system für heterologe proteine. Bioengineering, New York, 5: 20-6, 1990.

GENDRE, F. \& GUERINEAU, M. Constrution of an E. coli - yeast shuttle vector with a double positive selection in order to transform industrial strain od $S$. cerevisiae. Yeast, Chichester, 2: S127, 1986.

GIETZ, R.D. \& SCHIESTL, R.H. Aplications of high efficiency lithium acetate transformation of intact yeast cells using single stranded nucleic acids as carrier. Yeast, Chichester, 7: 253-63, 1991. 
GRITZ, L. \& DAVIES, J. Plasmid-endoced hygromycin B resistance: the sequence of hygromycin B phosphotransferase gene and its expression in Escherichia coli and Saccharomyces cerevisiae. Gene, Amsterdan, 25: 179-86, 1983.

HADFIELD, C.; CASHMORE, A.M.; MEACOOK, P.A. Sequence and expresison characteristics of a shutle chlorophenicol-resistance marker fo Saccharomyces cerevisiae and Escherichia coli. Gene, Amsterdan, 52: 59-70, 1987.

HADFIELD; RAINA, K.K.; SHASHI-MENON, K.; MOUNT, C. The expression and perfomance of cloned genes in yeasts, Mycological Research, Cambridge, 97: 897-944, 1993.

HARASHIMA, ; TAKAGI, A.; OSHIMA, Y. Transformation of protoplasted yeast cells is directly associated with cell fusion. Molecular Cellular Biology, Washington, 4: 771-8, 1984.

HARDFIELD, C.; JORDAN, B.E.; MOUNT, R.C.; PRETORIUS, G.H.J.; BURAKE, E. G418-resistance as a dominant marker and reporter for gene expression in Saccharomyces cerevisiae. Current Genetics, Berlin, 18: 303-13, 1990.

HIEP, T.T.; NOSKOV, V.N.; PAULOV, Y.I. Tranformation in the methylotrophic yeast Pichia methanolica utilizing homologous adel and heterologous Saccharomyces cerevisiae ade 2 and leu2 genes as genetic markers. Yeast, Chichester, 9: 1189-97, 1993.

HIGGINS, D.R. \& STRATHERN, J.N. Eletroporation simulated recombination in yeast. Yeast, Chichester, 7: 823-31, 1991. 
HINNEN, A.; HICKIS, J.B.; FINK, G.R. Transformation of yeast. Proceeding of the National Academy Science, USA, Washington, 75: 1929-33, 1978.

HOWLETT, B. An electrophoretic karyotype for Phytophthora megasperma. Experimental Mycology, New York, 13: 199-202, 1989.

HYMAN, B.C.; CRAMER, J.H.; ROWND, R.H. Properties of Saccharomyces cerevisiae DNA segment conferring hihg-frequency of yeast transformation. Proceeding of the National Academy Science USA, Washington, 79: 1578-82, 1982.

IIMURA, Y.; GOTOH, K.; OUCHI, K,; NISHIYA, T. Yeast transformation without spheroplasting process. Agricultural Biology Chemistry, Tokyo, 47: 897-901, 1983.

ITO, H,; FUKUDA, Y,; MURATA, K.; KIMURA, A. Tranformation of intact yeast cells treated with alkali cations. Journal of Bacteriology, Baltimore, 153: 163-8, 1983.

JAGER, D.; PHILIPPSEN, P. Many yeast chromosomes lack the telomese-specific Y'sequence. Molecular and Cellular Biology, Washington, 9: 5754-7, 1989.

JANG, J.K.; PYUM, Y.R.; SHIN, P.K.; SEO, J. Analysis of cloned suc2 gene expresison in continuous culture of recombinant Saccharomyces cerevisiae. Biotechnology Bioengineering, New York, 36: 960-4, 1990.

JIMENEZ, A. \& DAVIS, J. Expression of a transposable antibiotic resistant element in Saccharomyces. Nature, London, 287: 869-71, 1980. 
KASTER, K.R.; BURGET, S.G.; INGOLIA, T.D. Hygromycin B resistance as dominant selectable marker in yeast. Current Genetics, Berlin, 8: 353-8, 1984.

KASUSKE, A.; WEDLER, H.; SCHULZE, S.; BECHER, D. Efficient eletropulse transformation on intact Candida maltosa cells by different homologous vectos plasmid. Yeast, Chichester, 8: 691-7, 1992.

KAVA-CORDEIRO, V. Cariótipos eletroforéticos de linhagens selvagens e mutantes do fungo entomapatogênico Metarhizium anisopliase (METSCH) SOROKIN. 1993. 92p. (Mestrado - Universidade Federal do Paraná).

KINSCHERF, T.G. \& LEONG, S.A. Molecular analysis of karyotype of Ustilago maydes. Chromosoma, Berlin, 96: 427-33, 1988.

KNOWLTON, R.G. Copy number and stability of yeast plasmids.In: REZNIKOFF, W. \& GOLD, L. Maximmizing gene expression, Butterworks, Boston, 1986. cap. 4., 171-95.

KUNZE, G.; BODE, R.; RINTALA, H.; HOFEMESISTER, J. Heterologous gene expression of the glyfosate resistance marker and its application in yeast transformation. Current Genetics, Berlin, 15: 91-8, 1989.

La ROSSA, R.A. \& SCHOLS J.V. The sulfanylurea herbicide sulfometuron methyl is an extremely potent and selective inhibitor of acetolactate synthase in Salmonella typhimurium. Journal Biological Chemistry, Baltimore, 259: 8753-7, 1984.

LAI, E.; BIRREN, B.W.; CLARCK, S.M.; SIMON, M.I.; HOOD, L. Pulsed field gel electrophoresis. Biotechniques, Washington, 7: 34-42, 1989. 
LALANDE, M.; NOOLANDI, J.; TURMEL, C.; ROUSSEAU, J.; SLATER, G.W. Pulsed-field electrophoresis: Applicarion of a computer model to the separation of large DNA molecules. Proc. National Academy Science, Washington, 84: 8011$5,1987$.

LIVINGSTON, D.M. Inheritance of $2 \mu \mathrm{m}$ DNA plasmid fro Saccharomyces. Genetics, Princeton, 86: 73-84, 1977.

LOBRICH, M.; IKPEMES, S.; KIEPER, J. Analysis of the inversion effect in pulsed field gel electrophoresis by a two-dimensional contour clamped homogeneous eletric field system. Analytical Biochemistry, New York, 208: 65-73, 1993.

LODDER, J. The yeast, a taxonomic study, Amsterdan, North Holland, 1970, $1385 p$.

LONGO, A.C. Clonagem e caracterização do gene de resitência à nistatina em Saccharomyces cerevisiae, Piracicaba, 1991. 86p. (Mestrado - Escola Superior de Agricultura "Luiz de Queiroz"/ USP).

MACREEDIE. I.G.; JAGADISH, M.N.; AZAD, A.A.; UANGHAN, P.R. Versatile cassets designed for the cooper inducible expression of protein in yeast. Plasmid, San Diego, 21: 147-50, 1989.

MAGEE, B.B. \& MAGEE, P.T. Electrophoretic karyotype and chormosome numbers in Candida species. Journal of General Microbiology, London, 133: 425-30, 1987. 
MAGEE, B.B.; KOLTIN, Y.; J.A.; MAGEE, P.T. Assigment of cloned genes to the seven electrophoretically separated Candida albicans chromosomes. Molecular Cellular Biology, Washington, 8: 4721-6, 1988.

MANIATIS, T,; FRITISCH, E.F.; SAMBROOK, J. Molecular cloning: a laboratory amnual. Cold Spring Harbor Laboratory, New York, Col Spring Harbor, 1982, 545p.

MARUNOUCHI, T,; MATSUMOTO, Y.; HOSOYA, OKABAYASHI, $K$. In addition to the ARS box is necessary for autonomously replicating sequences. Molecular General Genetics, Berlin, 206: 60-5, 1987.

MASEL, A.; BRAITHWAITE, K.; IRWIN, J.; MANNERS, J. Highly varialble molecular karyotypes in Colletotrichum gloeosporoides pathogenic on Stylosanthes sp. Current Genetics, Berlin, 18: 81-6, 1990.

MATILDE, P.H.; MOOR, H.; ROBINOW, C.F. Yeast cytology. In: ROSE, A.H. \& HARRISON, J.S. eds. The yeasts, New York, Academic Press, 1969. v.1., p. 219-97.

MAZODIER, P.; CROSSART, P.; GIRAUD, E.; GASSER, F. Completion of the nucleotide of the central region of the TN5 confirms the presence of three resistance genes. Nucleic Acids Research, Oxford, 13: 195-200, 1985.

McCLUSKEY, K.; RUSSEL, B.W.; MILLS, D. Electrophoteric karyotyping without the need for generating protoplasts. Current Genetics, Berlin, 18: 385-6, 1990. 
McDONALD, B.A.; MARTINEZ, J.P. Chromoosome length polymorphisms in a Septoria triticipopulation. Current Genetics, Berlin, 19: 265-71, 1991.

MEILHOC, E.; MASSON, J.M.; TEISSIE, J. High efficiency transformation of intact yeast cells by eletric field pulses. Biotechnology, New York, 8: 223-7, 1990.

MIAO, V.P.W. Genes for phytoalexin detoxification in Nectria haematococca role in virulence on chickpea, and location on B chromosomes. PhD dissertation. Department of Plant Pathology, Cornell University, Ithaca, New York, 1990.

MIAO, V.P.M. \& VANETTEN, H.D. Preparing chromosomes from protoplast of filamentous fungus for pulsed-field gel electrophoresis. Biotechniques, Washington, 8: 393, 1990.

MILLS, D.; McCLUSKEY, K. Electrophoretic karyotypes of fungi. The new cytology. Molecular Plant-Microbe Interactions, St Paul, 3(6): 351-7, 1990.

MIZURAMI, T.; YAGISAWA, M.; FURUYA, A. Improvement of the stability of recombinat plasmids carrying the threonine operon in an L-threonine hyperproducing strain of $E$. coli W. Agricultural Biological Chemistry, Tokyo, 50: 1019-27, 1986.

MONTENEGRO, E.; FIERRO, F.; FERNANDEZ, F.J.; GUTIERREZ, S.; MARTIN, J.F. Resolution of chromosomes III and IV od Sapergillus nidulans by pulsed field gel electrophoresis shows that the penicillin biosyntetic pathway pcbAB, pcbC and penDE are clustered on chromosome VI (3,0 Megabases). Journal of Bacteriology, Baltimore, 174: 7063-67, 1992. 
MORTINER, R.K; CONTROPOULOU, C.R.; KING, J.S. Genetic and physical maps of Saccharomyces cerevisiae, Edition 11. Yeast, Chichester, 8: 817-902, 1992.

MURRAY, A.W. \& SZOSTAK, J.W. Pedigree analysis of plasmid segregation in yeast. Cell, Cambridge, 4: 961-70, 1983.

NAUMOV, G.I.; NAUMOVA, E.S.; MANTTO, R.A.; LOISE, E.J.; KORHOLA, M. Genetic homology between Saccharomyces cerevisiae and its sibling species $S$. paradoxus and S. bayanus: electrophoretic karyotypes. Yeast, Chichester, 8: 599$612,1992$.

NEUMANN, E.; WANG, Y.; HOFSCHNEIDER, P.H. Gene transfer into mouse lyoma cells by eletroporation in high eletric fields. EMBO Journal, Oxford, 1: 841-5, 1982.

NIETO, A.; SANZ, P.; SENTANDREAU, R.; AGUDO, L.D.C. Cloning and characterization of the sec18 gene from Candida albicans. Yeast, Chichester, 9: 875-87, 1993.

NISHIZAWA, M.; OZAWA, F.; HISHINUMA, F. Construction of yeast secretion vectors designed for production of mature proteins using the signal sequence of yeast invertase. Applied Microbiology and Biotechnology, Berlin, 32: 317-22, 1989.

NIWA, O. MATSUMOTO, T,; YANAGIDA, M. Construction of a minichromosome by deletion and its mitotic and meiotic behavour in fission yeast. Molecular Genetics, New York, 203: 397-405, 1986. 
OLIVER, S.G.; VAN DER AART, Q.J.M.; AGOSTONI-CARBONE, M.L. The complete DNA sequence of yeast chromossome III. Nature, London, 357: 38-46, 1992.

ORBACH, M.J.; VOLLRATH, D.; DAVIS, R.W.; YANOFSKY, C. An electrophoretic karyotype of Neurospora crassa. Molecular and Cellular Biology, Washington, 8: 1469-73, 1988.

ORBACH, M.J.; PORRO, E.B.; YANOFSKY, C. Cloning and characterization of the gene for B-tubulin from a benomyl resistant mutant of Neurospora crassa and its use as dominant selectable marker. Molecular and Cellular Biology, Washington, 6: $2452-61,1989$.

ORR-WEAVER, T.L. \& SZOSTAK, J,W. Multiple tandem plasmid integration in Saccharomyces cerevisiae. Molecular and Cellular Biology, Washington, 30: 747-9, 1983.

PIZZIRANI-KLEINER, A.A. \& AZEVEDO, J.L. Manual de técnicas eletroforéticas para separação de cromossomo de microrganismos, Piracicaba, FEALQ, 31p., 1989 (Manual Técnico).

PORRO, D. MARTEGANI, E.; RANZI, B.M.; ALBERGHINA, L. Heterologous gene expression in continuous cultures of budding yeast. Applied Microbiology and Biotechnology, Berlin, 34: 632-6, 1991.

QUEIROZ, M.V. Caracterização molecular e clonagem gênica em Aspergillus nidulans portador de duplicação cromossômica. 1993. $116 \mathrm{p}$ Tese (Doutorado) Escola Superior de Agricultura "Luiz de Queiroz/SP). 
REISER, J.; GLUMOFF, U.; KALIN, M.; OCHSNER, U. Transfer and expression of heterologous genes in yeasts other than Saccharomyces cerevisiae. Advances in Biochemics Engineering/Biotechnology, Berlin, 43: 76-102, 1990.

RIETVELD, K.; BAKHUIS, J.G.; JANSEN, N.J.; VAN LEEN, R.W.; NOORDERMEER, A.C.M.; VAN DOYEN, A.J.J.; SCHAAP, A.; VAN DEN BERG, J.A. Kluyveromyces as a host for heterologous gene expression. $14^{\text {th }}$ International Conference on Yeast Genetics and Molecular Biology, p.163, 1988.

ROMANOS, M.A.; SCORER, C.A.; CLARE, J. Foreign gene expression in yeast: a review. Yeast, Chichester, 8: 423-88, 1992.

RUOHOLA, H.; LILJESTROM, P.L.; TORKKELI, T.; KOPU, H.; LEHTINEN, P.; KORHOLA, M. Expression and regulation of the yeast mell gene. Fems Microbiology Letters, Amsterdan, 34: 179-85, 1986.

SANGLARD, D. \& FLECHTER, A. DNA transformations of Candida tropicales with replicating and integrative vectors. Yeast, Chichester, 8: 1065-1075, 1992.

SCHERER, S. \& DAVIS, R.W. Replacement of chromossome segments with altered DNA sequences constructed in vitro. Proceeding of the National Academy Science USA, Washington, 76: 49-51-5, 1979.

SCHWARTZ, D.C.; SAFFRAN, W.; WELSH, J.; HAAS, R.; GOLDENBERG, M.; CANTOR, C.R. Cold Spring Harbor Symposia on Quantitative Biology, New York, 47: 189-95, 1982. 
SCHWARTZ, D. \& CANTOR, C; R. Separation of yeast chromossome sized DNAs by pulsed field gradient gel electrophoresis. Cell, Cambridge, 37: 67-75, 1984.

SEMON, D.; MOUUS, N.R.; SMITH, T.F.; EL ALAMA, M.; DAVIES, J. Plamiddetermined bleomycin resistence in Staphylococcus aureus. Plasmid, San Diego, 17: 46-53, 1987.

SEWER, P. GEl electrophoresis with discontinuous rotation of the gel: an alternative to gel electrophoresis with changing direction of the electric . field. Electrophoresis, New York, 8: 301-4, 1987.

SKATRUD, P.L. \& QUEENER, S.W. An electrophoretic molecular karyotype for an industrial strain of Cephalosporium acremonium. Gene, Amsterdan, 78: 331-338, 1989.

SKINNER, D.Z.; BUDDE, A.D. \& LEONG, S.A. Molecular karyotype analysis of fungi. In: BENNETT, J.W. \& LASURE, L.L.; More Gene Manipulation in Fungi. New York, 1991, p. 87-103.

SKINNER, D.Z.; LEUNG, H.L.; LEONG, S.A. Genetic map of the blast fungus Magnoporthe grisea $(n=6)$. In: S.J. O'BRIEN, ed. Genetics maps, New York, Cold Spring Harbor Press, 1990. p. 382-3.

SMITH, C.L.; MATSUMOTO, T.; NIWA, O.; KLCO, S.R.; FAN, J.B.; YANAGIDA, M.; CANTOR, C.R. An electrophoretic karyotype for Schizosaccharomyces pombe by pulsed-field gel electrophoresis. Nucleic Acids Research, Oxford, 15: 4481-9, 1987. 
SOUTHERN, E.M.; ANAND, R.; BROWN, W.R.A.; FLETCHER, D.S. A model for the separation of large DNA molecules by crossed field gel electrophoresis. Nucleic Acids Research, Oxford, 15: 5925-43, 1987.

SREEKRISHNA, K. \& DICKSON, R.C. Construction of strains of Saccharomyces cerevisiae that grow on lactose. Proceeding of National Academy of Science USA, Washington, 86: 6260-3, 1989.

STEELE, P.E.; CARLE, G,; KOBAYASHI, S,; MEDOFF, G. Electrophoreticanalysis of Histoplasma capsulatum chromosomal DNA. Molecular Cellular Biology, Washington, 9: 983-7, 1989.

STEENSMA, H.Y.; DE JONGH, F.C.M.; LINNELAMP, M. The use of electrophoretic karyotypes in the classification of yeast Kluyveromyces marxianus and $K$. lactis. Current Genetics, Berlin, 14: 311-7, 1988.

STEWART, G.; FURS, A.; AVDALOVIC, N. Transverse alternating field electrophoresis (TAFE). Biotechniques, Washington, 6: 68-73, 1988.

STINCHCOMB, D.T.; STRUHL, K.; DAVIS, R.W. Isolation and characterization of a yeast chromosomal replication. Nature, London, 272: 39-43, 1979.

STRINGER, M.A.; DEAN, R.A.; SEWALL, C.T.; TIMBERLAKE, W.E. Rodletless, a new Aspergillus developmental mutant induced by directed gene inactivation. Genes \& Development, New York, 5: 1161-71, 1991. 
STRUHL, K.; STINCHCOMB, D.T.; SCHERER, S.; DAVIS, R.W. High frequency transformation of yeast: autonomous replication of hidric DNA molecules. Proceeding of the National Academy Science, USA, Washington, 76: 1035-9, 1979.

SUMRADA, R.A.; COOPER, T.G. The arginase (CAR1) gene is situated near MF21 on the right arm of chromosome XVI. Yeast, Chichester, 8: 311-4, 1992.

SZOSTAK, J.W.; BLACKBURN, E.H. The molecular structure of centromeres and telomeres. Annual Review of Biochemistry, Palo Alto, 53: 163-94, 1984.

TALBOT, N.J.; OLIVER, R.P.; CODDINGTON, A. Pulsed field gel electrophoresis reveals chromosome lenght differences between strains of Cladosporium fulvum (syn. Fulvia fulva). Molecular \& General Genetics, Berlim, 229: 267-72, 1991.

TAVARES, F.C.A. Processo de produção de etanol com controle de leveduras contaminantes. INPI. Patente $n^{\circ}$ 8.903.744, 1989.

TAVARES, F.C.A. Processo de controle seletivo de leveduras contaminantes. STAB, Açúcar, Álcool e Subprodutos, Piracicaba, 3: 45-9, maio/junho, 1992.

TEUNISSEN, A.W.R.H.; VAN DEN BERG, J.A.; STEENSMA, H.Y. Physical localization of the flocculation gene FLO1 on chromossome I of Saccharomyces cerevisiae. Yeast, Chichester, 9(1): 1-10, 1993.

TOOLEY, P.W.; CARRAS, M.M. Separation of chromosomes of Phytophthora species using CHEF gel electrophoresis. Experimental Mycology, San Diego, 16: 188-96, 1992. 
TOROK, T.; ROYER, C.; ROCKOHOLD, D.; KING, A.D.J. Eletrophoretic karyotyping of yeasts and southern blotting using whole chromosomes as templates for the probe preparation. Journal of General and Applied Microbiology, Tokyo, 38: 313-25, 1992.

VAN DER AAR, P.C.; VAN DER HEUVEL, J.J.; ROLING, W.F.M.; RAVE, H.A.; STOUTHAMER, A.H.; VAN VERSEVELD, H.W. Effects of phosphoglycerate kinase overproduction in Saccharomyces cerevisiae on the physiology and plasmid stability. Yeast. Chichester, 8: 47-55, 1992.

VARONI, M. \& LOTTI, M.A. Expression of clone glucomylase from S. diastativus under natural and inductible promoters. Biochemistry Biophysical Acta, New York, 1008: 168-76, 1989.

VIDAL, M. \& GARBER, R.F. Selectable marker replacement in Saccharomyces cerevisiae. Yeast, Chichester, 10: 141-9, 1994.

VOLLRATH, D. \& DAVIS, R.W. Resolution of DNA molecules greater than 5 megabases by contour-clamped homogeneous eletric fields. Nucleic Acids Research, Oxford, 15: 7865-76, 1987.

WEBSTER, T.D. \& DICKSON, R.C. Direct selection of Saccharomyces cerevisiae resistant to the antibiotic G418 following transformation with a DNA vector carrying the kanamycin-resistance gene Tn903. Gene, Amsterdan, 26: 243-52, 1983.

WINNACKER, E.L. From gene to clones: introduction to gene technology, Publish, Weinhein, cap.5., p. 179-207, 1987. 
ZAKIAN, V.A. \& KUPFER, D.M. Replication and segregation of an unstable plasmid in yeast. Plasmid, San Diego, 8: 15-8, 1982. 